\title{
HETEROSE E CAPACIDADE DE COMBINAÇÃO EM CRUZAMENTOS DIALÉLICOS PARCIAIS DE PIMENTÃo
}

\author{
LAFAYETE LUIZ DA SILVA
}

Dissertação apresentada à Escola Superior de Agricultura "Luiz de Queiroz", Universidade de São Paulo, para obtenção do título de Mestre em Agronomia, Área de Concentração: Genética e Melhoramento de Plantas.

P I R A C I C A B A

Estado de São Paulo - Brasil

Novembro - 2002 


\title{
HETEROSE E CAPACIDADE DE COMBINAÇÃO EM CRUZAMENTOS DIALÉLICOS PARCIAIS DE PIMENTÃo
}

\author{
LAFAYETE LUIZ DA SILVA
}

Engenheiro Agrônomo

Orientador: Prof. Dr. NATAL ANTONIO VELLO

Dissertação apresentada à Escola Superior de Agricultura "Luiz de Queiroz", Universidade de São Paulo, para obtenção do título de Mestre em Agronomia, Área de Concentração: Genética e Melhoramento de Plantas.

P I R A C I C A B A

Estado de São Paulo - Brasil

Novembro - 2002 


\section{Dados Internacionais de Catalogação na Publicação (CIP) DIVISÃO DE BIBLIOTECA E DOCUMENTAÇÃO - ESALQ/USP}

\section{Silva, La fayete Luiz da}

Heterose e capacidade de combinação em cruzamentos dia lélic os parcia is de pimentão / La fayete Luiz da Silva . - - Piracic aba, 2002.

$82 \mathrm{p}$.

Dissertação (mestrado) - - Escola Superior de Agricultura Luiz de Queiroz, 2002.

Bibliografia.

1. Combinação genética 2. Cruzamento dia lélico 3. Heterose 4. Melhora mento genético vegetal 5. Pimentão I. Titulo

CDD 635.643

"Permitida a cópia total ou parcial deste documento, desde que citada a fonte - $O$ autor" 
À minha esposa Luciana, pela compreensão e dedicação redobrada ao lar durante este meu período de ausência e pelo estímulo constante não somente neste projeto mas também em tantos outros, nestes ainda tão poucos anos de companheirismo.

Ao meu filho Gustavo, razão diária da minha busca incessante por vitórias na vida.

À minha mãe Maria Laice, pelo amor, orgulho e orações que tem ofertado a mim e pelo exemplo de dedicação e fé que tem demonstrado na difícil tarefa de criar cinco filhos diante de situações tão difíceis.

Ao meu tio Camilo, grande e maior de todos os pais, a quem devo a minha educação e a formação de meu caráter.

À minha prima Dolores pela amizade e carinho de verdadeira irmã e pelo estímulo constante na conquista de degraus mais altos na vida. 


\section{AGRADECIMENTOS}

A Deus, em primeiro lugar, por me proporcionar o desejo e os meios necessários para a realização deste trabalho.

A empresa Sakata Seed Sudamérica Ltda por me permitir a realização deste curso de Pós-Graduação, mostrando com este gesto o seu verdadeiro engajamento no sentido de investir no recurso humano que possui, que sem sombra de dúvida se traduz no maior patrimônio que uma empresa possa deter, demonstrando assim também, a sua valiosa contribuição social à medida que colabora para o engrandecimento de nossa nação ao apoiar a produção científica e a formação e valorização dos seus cidadãos; em particular, à pessoa do Dr. Paulo Tarcísio Della Vecchia pelo empenho pessoal e pelos constantes estímulos e ensinamentos que tornaram possível a realização deste grandioso projeto pessoal; ao amigo e companheiro nos projetos de pesquisa, Paulo Sérgio Koch, pelo apoio e estímulo na obtenção de novas conquistas e pela confiança e cobertura neste meu período de ausência; ao auxiliar de Pesquisa do setor de Solanáceas Luciano Peixoto de Faria pelo valioso auxilio na condução do experimento; aos funcionários do setor de Solanáceas pela condução, atenção e cuidados dispendidos ao experimento; a todos os amigos pelo apoio e companheirismo e em especial ao amigo de longa data Mauricio Gusmão Rangel por tantos momentos da vida compartilhados; às secretárias Natália e Elza pela colaboração constante; aos estagiários Ana Paula, Fábio, Fernanda, Rafael, Rogério e Sara pela colaboração nas tomadas de dados realizadas ao longo das avaliações. 
À Escola Superior de Agricultura "Luiz de Queiroz" pela oportunidade e formação acadêmica; ao professor Dr. Natal Antonio Vello pela amizade, ensinamentos e incentivos constantes, desde a época da graduação e pela prestimosa orientação neste trabalho; aos professores do Departamento de Genética da ESALQ/USP, pelos valiosos ensinamentos; aos funcionários do Departamento de Genética da ESALQ/USP pela amizade e colaboração.

Aos colegas do curso de Pós-Graduação, pela amizade e companheirismo. 


\section{SUMÁRIO}

Página

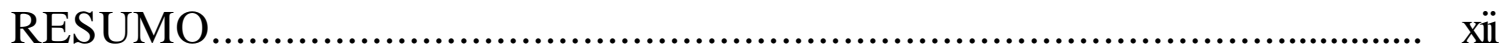

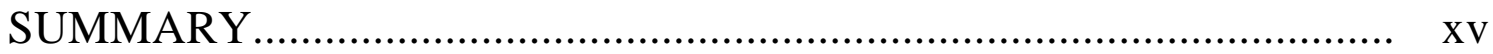

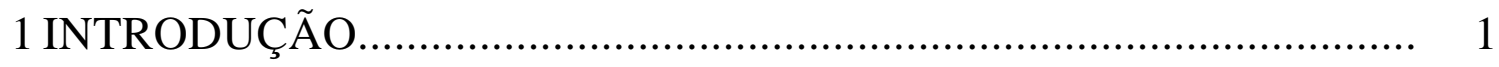

2 REVISÃO DE LITERATURA.......................................................... 5

$2.1 \mathrm{O}$ gênero Capsicum........................................................................ 5

2.2 Componentes da produtividade ...................................................... 9

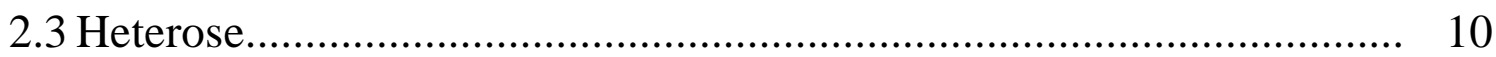

2.4 Heterose em Capsicum annuum.................................................... 11

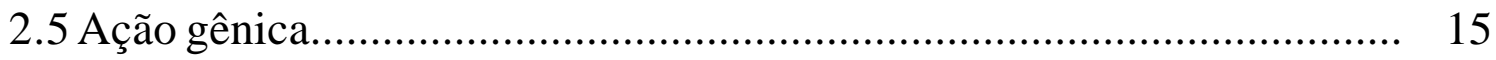

3 MATERIAL E MÉTODOS............................................................ 21

3.1 Material genético....................................................................... 21

3.2 Obtenção dos híbridos.................................................................. 22

3.3 Delineamento experimental......................................................... 24

3.4 Avaliação dos caracteres estudados................................................... 26

3.5 Análises genético-estatísticas......................................................... 28

3.5.1 Análise de variância.................................................................. 28

3.5.2 Análise dialélica.................................................................. 30

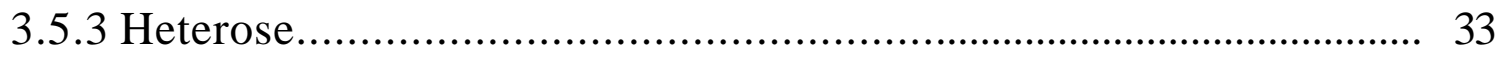

3.5.4 Testes de significância.................................................................. 34

4 RESULTADOS E DISCUSSÃO_................................................... 35

4.1 Análise de variância...................................................................... 35 
4.2 Avaliação dos híbridos e da heterose................................................ 38

4.2.1 Altura da planta na maturidade................................................... 38

4.2.2 Número de dias para o florescimento........................................... 43

4.2.3 Número de dias para a maturidade.................................................. 43

4.2.4 Produção de frutos por planta....................................................... 45

4.2.5 Número de frutos por planta........................................................... 48

4.2.6 Peso médio de fruto....................................................................... 49

4.2.7 Comprimento de fruto............................................................ 52

4.2.8 Diâmetro de fruto..................................................................... 54

4.2.9 Espessura de pericarpo de fruto.................................................... 56

4.2.10 Número de lóculos por fruto...................................................... 58

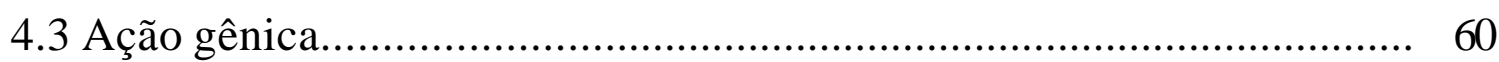

4.3.1 Altura de planta na maturidade .......................................................... 60

4.3.2 Número de dias para o florescimento............................................ 62

4.3.3 Número de dias para a maturidade.................................................. 62

4.3.4 Produção de frutos por planta.......................................................... 65

4.3.5 Número de frutos por planta......................................................... 65

4.3.6 Peso médio de fruto....................................................................... 65

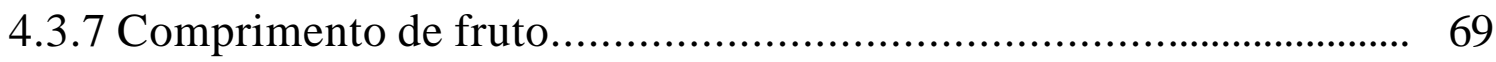

4.3.8 Diâmetro de fruto.............................................................................. 71

4.3.9 Espessura de pericarpo de fruto...................................................... 71

4.3.10 Número de lóculos por fruto........................................................... 74

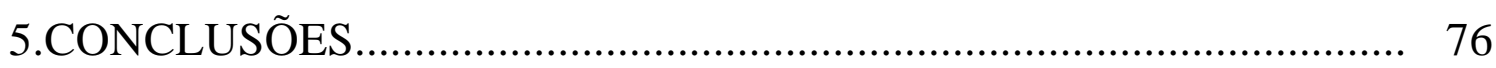

REFERÊNCIAS BIBLIOGRÁFICAS.................................................. 78 


\section{LISTA DE TABELAS}

Página

1 Tabela dialélica $4 \times 6$ com os dez genitores utilizados e os 24 híbridos resultantes......

2 Esquema da ANAVA, apresentando as esperanças dos quadrados médios para cada um dos dez caracteres avaliados, no delineamento blocos casualizados

3 Esquema da ANAVA, para um dialelo parcial, apresentando os desdobramentos dos tratamentos em grupos de genitores e da heterose em heterose média, de grupos e específica

4 Valores e significâncias dos quadrados médios, médias e coeficientes de variação da análise de variância, com base na média da parcela para os dez caracteres avaliados

5 Quadrados médios e significâncias, com os genótipos desdobrados em grupos (G1 e G2) e a heterose desdobrada em heterose média (h), de grupos $\left(h_{\mathbf{G} 1}\right.$ e $\left.h_{\mathbf{G} 2}\right)$ e específica $\left(h_{\mathbf{e}}\right)$ para os dez caracteres avaliados

6 Comparação entre médias : Teste de Scott-Knott para médias de quatro repetições de dez caracteres avaliados

7 Comparação entre médias : Teste de Dunnett para médias de quatro repetições de dez caracteres avaliados. 
8 Heterose em relação à média dos genitores $(\mathrm{MG})$, em relação ao genitor resistente ao PVY (GRPVY), em relaçãoao genitor suscetível ao PVY (GSPVY) e em relação ao híbrido-padrão (HP) para o caráter altura de planta na maturidade

9 Heterose em relação à média dos genitores $(\mathrm{MG})$, em relação ao genitor resistente ao PVY (GRPVY), em relação ao genitor suscetível ao PVY (GSPVY) e em relação ao híbrido-padrão (HP) para o

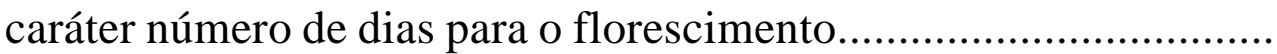

10 Heterose em relação à média dos genitores $(\mathrm{MG})$, em relação ao genitor resistente ao PVY (GRPVY), em relaçãoao genitor suscetível ao PVY (GSPVY) e em relação ao híbrido-padrão (HP) para o caráter número de dias para a maturidade

11 Heterose em relação à média dos genitores $(\mathrm{MG})$, em relação ao genitor resistente ao PVY (GRPVY), em relação ao genitor suscetível ao PVY (GSPVY) e em relação ao híbrido-padrão (HP) para o caráter produção de frutos por planta...............................................

12 Heterose em relação à média dos genitores $(\mathrm{MG})$, em relação ao genitor resistente ao PVY (GRPVY), em relação ao genitor suscetível ao PVY (GSPVY) e em relação ao híbrido-padrão (HP) para o caráter número de frutos produzidos por planta

13 Heterose em relação à média dos genitores $(\mathrm{MG})$, em relação ao genitor resistente ao PVY (GRPVY), em relação ao genitor suscetível ao PVY (GSPVY) e em relação ao híbrido-padrão (HP) para o caráter peso médio de fruto 
14 Heterose em relação à média dos genitores $(\mathrm{MG})$, em relação ao genitor resistente ao PVY (GRPVY), em relação ao genitor suscetível ao PVY (GSPVY) e em relação ao híbrido-padrão(HP) para o

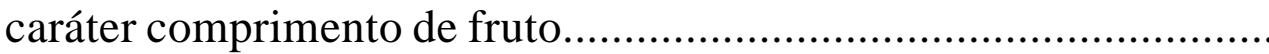

15 Heterose em relação à média dos genitores $(\mathrm{MG})$, em relação ao genitor resistente ao PVY (GRPVY), em relação ao genitor suscetível ao PVY (GSPVY) e em relção ao híbrido-padrão (HP) para o caráter diâmetro de fruto

16 Heterose em relação à média dos genitores $(\mathrm{MG})$, em relação ao genitor resistente ao PVY (GRPVY), em relação ao genitor suscetível ao PVY (GSPVY) e em relação ao híbrido-padrão (HP) para o caráter espessura de pericarpo de fruto

17 Heterose em relação à média dos genitores $(\mathrm{MG})$, em relação ao genitor resistente ao PVY (GRPVY), em relação ao genitor suscetível ao PVY (GSPVY) e em relação ao híbrido-padrão (HP) para o caráter número de lóculos por fruto..

18 Estimativas dos efeitos de média (u), de variedades "per se" (vi e vj), de heterose varietal (hi e hj), das capacidades geral (gi e gj) e específica (sij) de combinação para o caráter altura de planta na maturidade

19 Estimativas dos efeitos de média (u), de variedades "per se" (vi e vj), de heterose varietal (hi e hj), das capacidades geral (gi e gj) e específica (sij) de combinação para o caráter número de dias para o florescimento.

20 Estimativas dos efeitos de média (u), de variedades "per se" (vi e vj), de heterose varietal (hi e hj), das capacidades geral (gi e gj) e específica (sij) de combinação para o caráter número de dias para 
a maturidade.

21 Estimativas dos efeitos de média (u), de variedades "per se" (vi e vj), de heterose varietal (hi e hj), das capacidades geral (gi e gj) e específica (sij) de combinação para o caráter produção de frutos

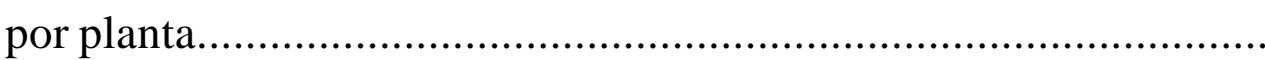

22 Estimativas dos efeitos de média (u), de variedades "per se" (vi e vj), de heterose varietal (hi e hj), das capacidades geral (gi e gj) e específica (sij) de combinação para o caráter número de frutos

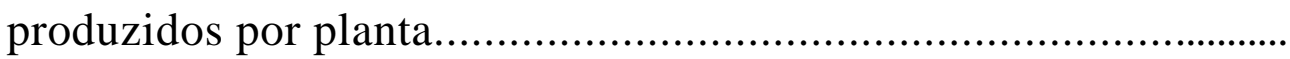

23 Estimativas dos efeitos de média (u), de variedades "per se" (vi e vj), de heterose varietal (hi e hj), das capacidades geral (gi e gj) e específica (sij) de combinação para o caráter peso médio de fruto

24 Estimativas dos efeitos de média (u), de variedades "per se" (vi e vj), de heterose varietal (hi e hj), das capacidades geral (gi e gj) e específica (sij) de combinação para o caráter comprimento de fruto.

25 Estimativas dos efeitos de média (u), de variedades "per se" (vi e vj), de heterose varietal (hi e hj), das capacidades geral (gi e gj) e específica (sij) de combinação para o caráter diâmetro de fruto ...

26 Estimativas dos efeitos de média (u), de variedades "per se"(vi e vj), de heterose varietal (hi e hj), das capacidades geral (gi e gj) e específica (sij) de combinação para o caráter espessura de pericarpo de fruto.

27 Estimativas dos efeitos de média (u), de variedades "per se" (vi e vj), de heterose varietal (hi e hj), das capacidades geral (gi e gj) e específica (sij) de combinação para o caráter número de lóculos por fruto 


\title{
HETEROSE E CAPACIDADE DE COMBINAÇÃO EM CRUZAMENTOS DIALÉLICOS PARCIAIS DE PIMENTÃo
}

\author{
Autor: LAFAYETE LUIZ DA SILVA \\ Orientador: Prof. Dr. NATAL ANTONIO VELLO
}

\section{RESUMO}

Este trabalho teve como objetivo estimar a natureza e a magnitude dos parâmetros genéticos, principalmente a heterose dos híbridos $\mathrm{F}_{1} \mathrm{e}$ as capacidades geral e específica de combinação em cruzamentos dialélicos parciais de pimentão (Capsicum annuum). Os genitores incluíram dois diferentes grupos de linhagens. $\mathrm{O}$ primeiro tem quatro linhagens resistentes ao PVY (AF3267, AF3269, AF3270 e AF3278) e o segundo grupo seis linhagens suscetíveis a esta virose (AF3248, AF3249, AF3252, AF3254, AF3255 e AF3256). Os 24 híbridos obtidos, os dez genitores e o híbrido-padrão Magali$\mathrm{R}$ foram testados em um delineamento de blocos ao acaso, com quatro repetições, em campo aberto, na Estação Experimental da Sakata Seed Sudamérica Ltda, localizada em Bragança Paulista-SP, no período de 18/10/99 a 17/03/00. Cada parcela experimental teve dez plantas totais e cinco plantas úteis. $\mathrm{O}$ espaçamento utilizado foi o de $0,50 \mathrm{~m}$ entre plantas dentro das parcelas e de $1,40 \mathrm{~m}$ entre as parcelas. Foram avaliados os seguintes caracteres : altura de planta na maturidade (APM), número de dias para o florescimento (NDF), número de dias para a maturidade (NDM), produção de frutos por planta 
(PFP), número de frutos por planta (NFP), peso médio de fruto (PMF), comprimento de fruto $(\mathrm{CF})$, diâmetro de fruto $(\mathrm{DF})$, espessura de pericarpo de fruto (EP) e número de lóculos por fruto (NL). As análises estatísticogenéticas foram feitas utilizando-se a metodologia de análise dialélica de Gardner \& Eberhart (1966) adaptada por Miranda Filho \& Geraldi (1984). Os principais resultados foram : 1)Valores significativos de heterose em relação à média dos genitores foram encontrados para os caracteres : altura de planta na maturidade $(-13,61$ a $7,15 \%)$, produção de frutos por planta (até 18,11\%), número de frutos por planta $(14,22 \%)$, peso médio de fruto (até 18,06\%), comprimento de fruto (-12,52 a 19,53\%), diâmetro de fruto (5,79\%), espessura de pericarpo de fruto (até 9,38\%) e número de lóculos por fruto $(6,11 \%)$;

2) Foram obtidos valores significativos de heterose em relação ao genitor resistente ao PVY para os caracteres altura de planta na maturidade $(-16,03$ a $35,84 \%$ ), produção de frutos por planta (até 60,21\%), número de frutos por planta (até 47,39\%) e espessura de pericarpo de fruto (até 18,38\%); 3) Ocorreram valores significativos de heterobeltiose para os caracteres peso médio de fruto (até 10,37\%), comprimento de fruto (até 15,74\%) e diâmetro de fruto $(5,60 \%) ; 4)$ Houveram valores significativos de heterose em relação ao híbrido-padrão Magali-R para os caracteres produção de frutos por planta $(29,27 \%)$, peso médio de fruto (até $25,73 \%$ ), comprimento de fruto (até $25,28 \%$ ), diâmetro de fruto (até $23,58 \%$ ), espessura de pericarpo de fruto (até $32,97 \%$ ) e número de lóculos por fruto (13,35\%); 5) Houve maior predominância dos efeitos gênicos aditivos para os caracteres altura de planta na maturidade, número de dias para o florescimento, produção de frutos por planta, número de frutos por planta, espessura de pericarpo de fruto e número de lóculos por fruto. Os efeitos gênicos não-aditivos foram mais importantes para os caracteres : número de dias para a maturidade; peso médio, 
comprimento e diâmetro de fruto; 6) Valores significativos das heteroses média, do grupo 2 e específica foram observados para os caracteres : altura de planta na maturidade, peso médio e comprimento de fruto, indicando a contribuição de ambas capacidade geral e específica de combinação. 


\title{
HETEROSIS AND COMBINING ABILITY IN PARTIAL DIALLEL CROSSES OF PEPPER
}

\author{
Author: LAFAYETE LUIZ DA SILVA \\ Adviser: Prof. Dr. NATAL ANTONIO VELLO
}

\section{SUMMARY}

This research aimed to estimate the nature and magnitude of genetic parameters, mainly the heterosis of F1 hybrids and both general and specific combining ability in a partial diallel crossing system of pepper (Capsicum апnиит). The parents included two different groups of lines : the first one has four PVY resistant lines (AF3267, AF3269, AF3270 and AF3278), and the second group of parents has six susceptible lines for this virosis (AF3248, AF3249, AF3252, AF3254, AF3255 and AF3256). The 24 obtained hybrids, the ten parental lines and the check cultivar Magali-R were tested in a randomized block design, with four replications, under field conditions, at Sakata Seed Sudamérica Ltda Research Station, located in Bragança Paulista, state of São Paulo, during the 10/18/99 to 03/17/00 period. Each experimental plot had ten total plants and five useful plants. The spacing used was $0.50 \mathrm{~m}$ between plants inside the plot and $1.40 \mathrm{~m}$ between plots. The following characters were evaluated : plant height at maturity (APM), number of days to flowering (NDF), number of days to maturity (NDM), fruit yield per plant 
(PFP), number of fruits per plant (NFP), average fruit weight (PMF), fruit length $(\mathrm{CF})$, fruit diameter (DF), fruit pericarp thickness (EP) and number of locules per fruit (NL). The statistic-genetical analysis were done by using the methodology of diallel system of Gardner \& Eberhart (1966) adapted by Miranda Filho \& Geraldi (1984). The main result were : 1) Significant values of heterosis in relation to mid parent values were found out to the characters : plant height at maturity (-13.61 to $7.15 \%$ ), fruit yield production (up to $18.11 \%)$, number of fruits per plant (14.22\%), average fruit weight (up to $18.06 \%)$, fruit length (-12.52 to $19.53 \%)$, fruit diameter (5.79\%), fruit pericarp thickness (up to 9.38\%) and number of locules per fruit (6.11\%); 2) They were obtained significant values of heterosis in relation to PVY resistant parent to the characters plant height at maturity (-16.03 to 35.84\%), fruit yield per plant (up to $60.21 \%$ ), number of fruit per plant (up to $47.39 \%$ ) and fruit pericarp thickness (up to 18.38\%); 3) Significant values of heterobeltiosis occurred to the characters fruit length (up to 15.74\%), average fruit weight (up to 10.37\%) and fruit diameter $(5.60 \%)$; 4) There were significant values of heterosis in relation to the standard Magali-R to the characters fruit yield per plant (29.27\%), average fruit weight (up to $25.73 \%$ ), fruit length (up to $-25.28 \%$ ), fruit diameter (up to 23.58\%), fruit pericarp thickness (up to 32.97\%) and number of locules per fruit $(13.35 \%)$; 5) There was higher predominance of additive genetic effects to the characters plant height, number of days to flowering, fruit yield per plant, number of fruits per plant, fruit pericarp thickness and number of locules per fruit. The non-additive genetic effects were more important to the characters : number of days to maturity, average weight, length and diameter of fruit; Significant values of medium, from group 2 and specific heterosis were observed to the characters : plant height at 
maturity, average weight and length of fruit, indicating the contribution of both general and specific combining ability. 


\section{INTRODUÇÃO}

A espécie Capsicum annuum L. $(2 \mathrm{n}=24)$ é composta por pimentas e pimentões, estes provavelmente originados de uma mutação espontânea. As diferenças principais são a pungência e o tamanho do fruto, sendo que no geral as pimentas possuem frutos pequenos e pungentes enquanto que os pimentões possuem frutos grandes e não pungentes.

O emprego comercial de cultivares híbridos F1 de pimentão no mercado brasileiro tem hoje uma importância muito grande. Até os anos 70 , a produção de pimentão no Brasil era representada exclusivamente por cultivares de polinização aberta. Nos anos 80, alguns híbridos de pimentão começaram a surgir no Brasil, via importação de sementes. Porém, por terem sido desenvolvidos em países de clima temperado, os híbridos introduzidos não tinham uma boa adaptação para a produção em campo aberto, sob as condições tropicais predominantes no Brasil, que favorecem o aparecimento de muitas doenças que não são problemáticas no hemisfério norte, ficando assim o uso dos mesmos restrito à produção em sistema de cultivo protegido. Somente nos anos 90, com o lançamento dos primeiros híbridos F1 por parte de companhias privadas de sementes de hortaliças, que desenvolviam atividades de pesquisa na condição de clima tropical brasileiro, é que se iniciou um crescimento significativo no uso de cultivares híbridos no mercado brasileiro, onde predomina a produção de pimentão em condição de campo aberto. 
As vantagens na utilização de híbridos estão fundamentadas na combinação de diferentes caracteres qualitativos e quantitativos, como por exemplo, a reunião no híbrido de genes de resistência às diferentes doenças que se encontram separados nos genitores envolvidos, o que propicia uma maior homeostase e a possibilidade de exploração da heterose para caracteres importantes como produtividade e qualidade do produto final.

Além disso, os híbridos têm funcionado como uma espécie de patente para as empresas da iniciativa privada de sementes, pois os mesmos representam a segurança sobre a exclusividade na exploração comercial dos produtos gerados, pois inibem a "pirataria" sobre as suas criações. Desta forma, as empresas particulares de sementes podem ter a garantia do retorno dos investimentos realizados e, assim, continuarem investindo no melhoramento, visando a obtenção de cultivares superiores.

Nos programas de melhoramento, é necessário que a seleção de genótipos superiores seja feita da maneira mais eficiente possível. Nas diversas espécies, essa superioridade se dá, normalmente, mediante a variável produtividade, que é resultado da interação de fatores genéticos e ambientais (Tavares et al., 1999).

Em um programa de melhoramento deve-se dar importância aos estudos genéticos dos caracteres agronômicos como uma forma de avaliar o potencial genético dos genitores para produzir melhores descendentes, assim como para aumentar a eficiência dos métodos de melhoramento. O grau de heterose manifesta a perspectiva para a obtenção de híbridos (Vallejo et al., 1997).

O sucesso de qualquer programa de melhoramento é dependente principalmente da seleção de genitores juntamente com a informação que 
considera a natureza e a magnitude do efeito gênico controlando caracteres de importância econômica (Patel et al., 1998).

No desenvolvimento de híbridos de alta produtividade, o melhorista frequentemente se depara com problemas relacionados à seleção de genitores e cruzamentos. A prática comumente utilizada da seleção de genitores com base na avaliação "per se" nem sempre gera bons resultados. Prioritariamente, a seleção de genitores deve ser baseada na informação genética completa, destacando-se o conhecimento da capacidade combinatória dos mesmos. A análise da capacidade de combinação é considerada ser uma técnica eficiente não apenas para a seleção de genitores e cruzamentos desejáveis, mas também por caracterizar a natureza e a magnitude da ação gênica na expressão de um caráter (Ahmed et al., 1998).

A análise da capacidade combinatória geral permite identificar os genitores com capacidade para transmitir seus caracteres desejáveis à descendência e a capacidade combinatória específica possibilita conhecer combinações híbridas $F_{1}$ superiores (Vallejo et al., 1997).

Uma maneira de se estimar as capacidades geral e específica de combinação de genitores é através da realização de cruzamentos dialélicos parciais, os quais se baseiam nas combinações gênicas entre genitores pertencentes a diferentes grupos, sendo estes últimos divergentes em um ou mais caracteres. Esta metodologia permite uma redução no número total de cruzamentos necessários, quando comparada a um dialelo completo. Nesta pesquisa, os dois grupos de genitores envolvidos diferem principalmente na reação ao PVY (Potato Virus Y ou Vírus Y da Batata), estirpe 1-2, uma doença limitante para o cultivo do pimentão, nas principais regiões produtoras do Brasil. Como a resistência ao PVY é condicionada por um gene dominante, todos os híbridos $F_{1}$ do dialelo também devem ser resistentes a esta doença. 
O objetivo desta pesquisa é avaliar a heterose, a heterobeltiose e a heterose-padrão de seus híbridos bem como a capacidade específica e geral de combinação (CEC e CGC, respectivamente) de dois grupos de genitores de pimentão, para caracteres agronômicos importantes para o valor comercial. 


\section{REVISÃO DA LITERATURA}

\subsection{O Gênero Capsicum}

Todas as espécies do gênero Capsicum, exceto $C$. anomalum, são originárias da América Tropical. Uma porção importante do gênero Capsicum se originou em uma área principal na Bolívia com subsequente migração aos Andes e terras baixas da Amazônia, acompanhada por dispersão e especiação. A espécie $C$. chacoense ou um ancestral seu deu origem tanto ao grupo de flores brancas como ao grupo de flores purpúreas. O grupo de flores purpúreas (C. eximium) migrou às terras altas dos Andes, com a consequente seleção

direcional que originou $C$. cardenasi por efeito fundador e $C$. pubescens como espécie domesticada. $\mathrm{O}$ grupo de flores brancas migrou para fora da área principal através das águas do rio Mizque, originando C. baccatum no sul da Bolívia. A forma silvestre continuaria migrando pelas águas dos rios locais e na úmida Bacia Amazônica daria origem ao ancestral silvestre do complexo $C$. aпnиит (Mc Leod et al., 1982 citado por Nuez et al., 1996).

O processo de domesticação parece ter ocorrido de maneira independente em diferentes regiões da América Latina. Acredita-se que $C$. pubescens e $C$. baccatum tenham sido domesticadas na Bolívia, C. chinense na Amazônia e C. annuum no México. Restos arqueológicos domesticados de Capsicum têm sido encontrados em sítios arqueológicos no Peru e datados de até 8500 a.C., o que faz do gênero Capsicum um dos primeiros gêneros a ter 
plantas domesticadas na América do Sul. No México, os restos arqueológicos mais antigos de pimenta que se tem encontrado datam de 6500 a.C (Nuez et al., 1996).

Em meados do século XVI já se plantava $C$. annuum na Índia, levada para o Oriente Médio pelos colonizadores espanhóis, por ser mais ardida e por se constituir em uma alternativa mais barata que a pimenta-do-reino (Piper nigrum) e cujo o monopólio sobre a comercialização era dos portugueses. No mesmo século já se podia encontrar pimentas de outras espécies do gênero Capsicum na Europa e na África (C. frutescens e C. chinense, principalmente) e no século seguinte, já estavam presentes na Oceania. Eram utilizadas não só como tempero para os alimentos mas também como conservante dos mesmos e também para evitar parasitas intestinais. Portanto, comparada a outras solanáceas hoje importantes na alimentação humana, como por exemplo o tomate e a batata, os quais foram cultivados exclusivamente como ornamentais logo após as suas respectivas introduções na Europa, a pimenta foi aceita e difundida de uma maneira muito mais rápida na dieta dos povos europeus e seus vizinhos asiáticos e africanos (Casali \& Couto, 1984 ; Nuez et al., 1996).

O nome científico do gênero Capsicum deriva do grego : segundo alguns autores, de Kapso (picar), segundo outros de Kapsakes (cápsula) e a palavra pimenta aparece na língua castelhana no século XIII, derivada do latim pigmenta, plural de pigmentum, corante (Nuez et al., 1996).

A taxonomia dentro do gênero Capsicum é complexa, devido à grande variabilidade de formas existentes nas espécies cultivadas e à diversidade de critérios utilizados na classificação. Pelo menos 30 espécies diferentes são reconhecidas. Cinco espécies são aceitas como cultivadas : $C$. annuum, C. baccatum, C. chinense, $C$. frutescens e C. pubescens, das quais 
apenas a última não é cultivada no Brasil (Bosland \& Votava, 2000 ; Casali \& Couto, 1984 ; Nuez et al., 1996).

A espécie $C$. annuum é a mais cultivada e a que apresenta a maior variabilidade (Casali \& Couto, 1984). Dois diferentes produtos olerícolas pertencem a esta espécie : a pimenta e o pimentão, este último se originando, provavelmente, de uma mutação espontânea da primeira. As demais espécies possuem apenas pimentas, sendo estas, na maior parte dos casos, pungentes.

As espécies cultivadas do gênero Capsicum são diplóides e têm 2n=24 cromossomos (Pickersgill, 1969). As espécies cultivadas possuem flores hermafroditas que apresentam protoginia.

O sistema reprodutivo no gênero Capsicum varia consideravelmente com a espécie e a variedade. Nas formas não domesticadas e nas domesticadas de frutos pequenos, geralmente o estigma se posiciona acima das anteras, fazendo prevalescer a alogamia. A presença de nectários também indica uma adaptação filogenética à alogamia mediante polinização entomófila. Nas outras formas, o estilo costuma ser mais curto, com um alto grau de autogamia (Nuez et al., 1996). A taxa de cruzamento natural no gênero Capsicum varia de 2 a 90\% (Pickersgill, 1997).

O cultivo comercial de pimentão no Brasil teve origem no início do século passado, época em que um agricultor chamado Carlos Junger, em Mogi das Cruzes, no Estado de São Paulo, cultivava pimentão de frutos cônicos de origem espanhola. Por volta de 1950, começava a surgir nas lavouras de pimentão uma doença causada pelo vírus $\mathrm{Y}$ da batata, conhecida como mosaico. No início dos anos 60, ao ser realizado um experimento de competição de cultivares de pimentão em Mogi das Cruzes, identificou-se a cultivar denominada Casca Grossa como sendo resistente a esta virose. No entanto, nos anos seguintes, surgiram diferentes estirpes deste vírus. Em 
função deste acontecimento, o Instituto Agronômico de Campinas iniciou um projeto de pesquisa visando criar novas cultivares de pimentão que fossem resistentes às estirpes de mosaico existentes. Dez anos mais tarde, surge a primeira cultivar com resistência a várias estirpes do vírus $\mathrm{Y}$ da batata : Agronômico 10G. Na sequência, surgem outras cultivares : Margareth, Magda, Sul Brasil, Agronômico 9, Agronômico 11 (pimenta doce) e Agronômico 12 (pimenta ardida).

Atualmente, a cultivar de pimentão líder de mercado para a produção em campo aberto e para a venda como pimentão verde é o híbrido Magali-R, que possui resistência às estirpes 0,1 e 1-2, esta última predominante no Brasil.

Esforços têm sido feitos por pesquisadores de muitos países no sentido de se criar cultivares resistentes a outros tipos de doenças causadas por patógenos como por exemplo o fungo Phytophthora capsici, a bactéria Xanthomonas campestris pv. vesicatoria e o vírus CMV (Cucumber Mosaic Virus).

No Brasil, atualmente, o pimentão está entre as dez hortaliças mais importantes, sendo plantado em todas as regiões do país, principalmente no sudeste.

Dentre os maiores produtores mundiais de pimentão destacam-se : Turquia ( $25 \%$ de toda a produção da Costa do Mediterrâneo), Espanha e Itália (30\% da produção desta região). Outro grande produtor é a China que produz 25\% do total mundial. Seguem Nigéria, México, Indonésia e Estados Unidos (Namesny, 1996 ; FAO, 1998). Entre os principais usos industriais dos pimentões e das pimentas estão : melhoria do "flavour" dos alimentos, coloração de cosméticos, indústria farmacêutica e "spray" de pimenta para uso da polícia. 
Além disso, o pimentão e a pimenta contêm vitaminas A, C, B1, B2. Por exemplo : três a quatro gramas de pimentão vermelho fornecem os requerimentos diários de vitamina A de uma pessoa adulta (Lantz, 1943 citado por Bosland \& Votava, 2000) e frutos verdes frescos de pimentão podem conter mais que $340 \mathrm{mg}$ de vitamina $\mathrm{C}$ por grama de fruto (Sviribeley \& Szent-Gyorgyi, 1933 citado por Bosland \& Votava, 2000).

O pimentão (Capsicum annuum L.) é uma das hortaliças mais importantes dos trópicos devido ao volume de sua produção, ao valor crescente da mesma e à grande demanda por parte dos consumidores (Vallejo et al., 1997).

\subsection{Componentes da produtividade}

Kordus (1991) obteve, de um dialelo completo envolvendo seis diferentes linhagens de pimenta (C. annuum), resultados que indicavam ser a heterobeltiose encontrada para produtividade em alguns híbridos a consequência principalmente de um maior número de frutos por planta.

Joshi et al. (1991), a partir de cruzamentos entre grupos divergentes de $C$. annuиm (pimentas e pimentões), obtiveram valores elevados (até $324,6 \%$ ) de heterose em relação aos parentais do grupo pimenta para o caráter

produção total e, segundo os autores, os mesmos resultaram da combinação entre as heteroses obtidas para os caracteres altura de planta, tamanho de fruto e número de frutos por planta.

\subsection{Heterose}


A heterose é um termo empregado para descrever a manifestação de um aumento no valor de um caráter quantitativo em híbridos de plantas ou animais. Comumente, a heterose também é denominada de vigor de híbrido.

A heterose se manifesta quando o caráter avaliado no híbrido é maior (heterose positiva) ou menor (heterose negativa) do que a média dos genitores.

Do ponto de vista aplicado, é mais comum o cálculo da heterose em relação ao genitor superior (heterobeltiose) ou a uma cultivar de importância econômica (heterose-padrão).

Em hortaliças tem sido possível explorar a heterose em espécies alógamas como melão, melancia, abóbora, pepino, couve-flor, brócolo, repolho, cenoura e cebola (Pearson, 1983) assim como em autógamas como tomate (Miranda, 1978), pimentão (Ikuta \& Vencovsky, 1970) e berinjela (Ikuta, 1961).

A quantidade de heterose produzida em um cruzamento entre dois genitores depende da diferença da frequência gênica entre os mesmos para os locos envolvidos na expressão de uma determinada característica. Não havendo esta diferença, não ocorrerá heterose. Se esta diferença existir em mais de um loco, os valores individuais de cada um destes locos se combinarão aditivamente e a heterose produzida poderá ser representada pelo efeito conjunto de todos os locos como a soma de suas contribuições separadas. Para que ocorra heterose é necessário que exista dominância, pois locos sem dominância não geram heterose. Se alguns locos forem dominantes em uma direção e outros em outra, seus efeitos tenderão a se cancelar e nenhuma heterose poderá ser observada, apesar da dominância nos locos individuais (Falconer, 1987).

\subsection{Heterose em Capsicum. annuum}


Ikuta \& Venkovsky (1970) e Ikuta (1971) verificaram que o pimentão apresenta vigor de híbrido e que, portanto, é possível produzir híbridos mais produtivos do que cultivares de polinização aberta.

\section{a) Altura de planta}

Ahmed \& Muzafar Hurra (2000) encontraram valores significativos de heterobeltiose $(43,31 \%)$ para o caráter altura de planta em pimentão; BenChaim \& Paran (2000), em cruzamentos intraespecíficos de pimenta e pimentão, identificaram heterose para esse caráter. Em pimenta, Gopalakrishnan et al. (1987), também observaram heterose significativa (7,68\%) para altura de planta ; Doshi \& Shukla (2000a), Kumar \& Lal (2001) e Mishra et al. (1988) relataram terem encontrado quantidades consideráveis de heterobeltiose $(24,23 \%, 12,45 \%$ e $22,13 \%$, respectivamente) para altura de planta.

\section{b) Número de dias para o florescimento}

Ming et al. (1986) trabalhando com cruzamentos envolvendo pimentões e pimentas, obtiveram valores significativos de heterose $(-5,69 \%)$ para o caráter número de dias para florescimento (NDF); Kumar et al. (2000) observaram valores de heterose e heterobeltiose, respectivamente, de $-55,3 \%$ e $-40,5 \%$, para o caráter número de dias para o aparecimento do primeiro fruto, também em cruzamento entre pimenta e pimentão ; Patel et al. (1998) também relataram efeitos significativos de heterose para NDF em pimenta ; Doshi \& Shukla (2000a) e Mishra et al. (1988) obtiveram, também em pimenta, quantidades consideráveis de heterobeltiose $(-26,34 \%$ e $-45,23 \%$, respectivamente) para NDF. 


\section{c) Número de dias para a maturidade}

Em pimenta, Patel et al. (1998) observaram efeitos significativos de heterose para o número de dias para a maturidade de frutos ; Doshi \& Shukla (2000a) e Mishra et al. (1988) obtiveram quantidades consideráveis de heterobeltiose $(-32,03 \%$ e $-27,62 \%$, respectivamente) para esse caráter ; Kumar \& Lal (2001), relataram terem encontrado heterobeltiose de $-14,65 \%$ para o caráter número de dias para a primeira colheita.

\section{d) Produção total}

Em pimentão, tanto Ming et al. (1986) quanto Miranda (1987) verificaram a ocorrência de heterose para produção total de frutos por planta (54,7\% e 59,91\%, respectivamente); Ikuta \& Vencovsky (1970) também observaram a ocorrência de heterose para produção; Depestre \& Espinosa (1988) encontraram a manifestação de heterose e heterobeltiose de 16,6 a $29,5 \%$ e 9,8 a 19,6\%, respectivamente; Melo (1997) relatou valores de até $46,07 \%$ de heterobeltiose para este caráter em híbridos triplos; Ahmed \& Muzafar Hurra (2000) e Mamedov \& Pyshnaja (2001) encontraram altos valores de heterobeltiose $(174,52 \%$ e $181,2 \%$, respectivamente) para produção total; Kumar et al. (2000) observaram valores de $111 \%$ e $100,2 \%$ de heterose e heterobeltiose, respectivamente, para produção, em cruzamento entre pimenta e pimentão. Em pimenta, Patel et al. (1998) relataram efeitos significativos de heterose para produção de frutos por planta; Bhagyalakshmi et al. (1991) relataram manifestações muito altas da ordem de $110,5 \%$ de heterose para o

caráter produção; Doshi et al. (2001) observaram valores de heterose e de heterobeltiose de $77,9 \%$ e $64,2 \%$, respectivamente, para tal caráter; Doshi \& Shukla (2000a), Kordus (1991) e Kumar \& Lal (2001) obtiveram quantidades 
consideráveis de heterobeltiose $(57,53 \%, 120 \%$ e $105,87 \%$, respectivamente) para produção; Mishra et al. (1988) relataram valores de heterobeltiose de $110,88 \%$ para produção total de frutos secos por planta.

\section{e) Número de frutos por planta}

Ikuta (1971) e Ikuta \& Vencovsky (1970) observaram a ocorrência de heterose para o caráter número de frutos por planta em pimentão; Miranda (1987) obteve heterose de 30,8\% ; Depestre \& Espinosa (1988) encontraram a manifestação de heterose e heterobeltiose de 11 a $28 \%$ e 12,5 a $20 \%$, respectivamente para este caráter; Mamedov \& Pyshnaja (2001) observaram altos valores de heterobeltiose $(183,6 \%)$ para número de frutos por planta; Ahmed \& Muzafar Hurra (2000) também encontraram valores significativos de heterobeltiose $(71,73 \%)$ para tal caráter. Em pimenta, Bhagyalakshmi et al. (1991) obtiveram manifestações muito altas $(160,3 \%)$ de heterose para o caráter número de frutos por planta, assim como Patel et al. (1998) também relataram significativos efeitos de heterose para o mesmo caráter; Doshi \& Shukla (2000a), Kumar \& Lal (2001) e Mishra et al. (1988) relataram heterobeltioses de $78,81 \%, 64,80 \%$ e $66,66 \%$, respectivamente, para número de frutos produzidos por planta.

\section{f) Peso médio de fruto}

Panayotov et al. (2000) observaram valores positivos e altos de heterose para peso de fruto em cruzamentos feitos utilizando tipos divergentes de pimentão para este caráter ; entretanto, Todorova (2000) encontrou valores negativos de heterose em seu trabalho; Miranda (1987) obteve heterose de 52,9\% para peso médio de frutos amostrados; Ming et al. (1986), em cruzamentos entre pimentões e pimentas, obtiveram valores de heterose de 
$60,71 \%$ para peso de fruto; Ahmed \& Muzafar Hurra (2000) encontraram valores de heterobeltiose de 71,73\% para este caráter ; Mamedov \& Pyshnaja (2001) observaram alto valor de heterobeltiose $(129,7 \%)$ para peso de fruto. Em pimenta, Doshi \& Shukla (2000a) obtiveram valores baixos de heterobeltiose para esse caráter (8,36\%) enquanto Mishra et al. (1988) relataram valores de heterobeltiose de $50,98 \%$ para o peso de dez frutos frescos em pimenta.

\section{g) Comprimento de fruto}

Para o comprimento de fruto, em pimentão, Panayotov et al. (2000) encontraram valores positivos e altos de heterose; Ahmed \& Muzafar Hurra (2000) obtiveram heterobeltiose de 29,03\%, ao passo que Mamedov \& Pyshnaja (2001) observaram heterobeltiose de 116,3\%. Em pimenta, Patel et

al. (1998) relataram efeitos significativos de heterose para comprimento de fruto; Gopalakrishnan et al. (1987) obtiveram heterose de 23,24\%; Kumar \& Lal (2001), Doshi \& Shukla (2000a) e Mishra et al. (1988) relataram valores de heterobeltiose de $15,67 \%, 57,14 \%$ e $63,85 \%$, respectivamente, para esse caráter.

\section{h) Diâmetro de fruto}

Em pimentão, para o caráter diâmetro de fruto, valores altos e positivos de heterose foram observados por Panayotov et al. (2000); heterobeltiose de 24,94\% foi encontrada por Ahmed \& Muzafar Hurra (2000), enquanto Mamedov \& Pyshnaja (2001) obtiveram heterobeltiose de 105,3\% para este caráter. Em pimenta, Patel et al. (1998) relataram efeitos significativos de heterose para largura de fruto; Doshi \& Shukla (2000a) 
observaram valor alto de heterobeltiose $(61,90 \%)$ para esse caráter ; Mishra et al. (1988) obtiveram heterobeltiose de 47,07\% para a circunferência de fruto.

\section{i) Espessura de pericarpo de fruto}

Panayotov et al. (2000) relataram valores altos e positivos de heterose para o caráter espessura de pericarpo de fruto em pimentão ; Mamedov \& Pyshnaja (2001) obtiveram valores altos de heterobeltiose $(108,2 \%)$ ao passo que Ahmed \& Muzafar Hurra (2000) observaram valores de heterobeltiose de 35,29\%. Kumar \& Lal (2001), trabalhando com pimenta, obtiveram heterobeltiose de $25 \%$ para esse caráter.

\section{j) Número de lóculos por fruto}

Em pimentão, para o número de lóculos por fruto, Miranda (1987) obteve baixos valores $(6,5$ e 8,2\%) de heterose positiva em dois de 15 híbridos que avaliou.

\subsection{Ação gênica}

Os trabalhos de melhoramento em pimentão têm sido realizados principalmente nos EUA, Brasil, Bulgária, França, Hungria, Índia, Japão e na antiga União Soviética. Em sua maioria, estas pesquisas mostraram que na expressão dos principais caracteres quantitativos intervêm, de forma conjunta e muito significativa, os efeitos gênicos aditivos e não-aditivos.

\section{a) Altura de planta}


Em pimentão, Miranda (1987) identificou predominância de efeito gênico não-aditivo para altura de planta ; Ahmed et al. (1997) observaram maior magnitude dos efeitos não-aditivos no controle desse caráter. Em pimenta, Ahmed et al. (1998) também encontraram magnitudes maiores das ações gênicas não-aditivas para altura de planta; porém Doshi \& Shukla (2000b), trabalhando com quatro variedades doces e seis pungentes, observaram ser a magnitude dos efeitos aditivos maior do que dos efeitos nãoaditivos, assim como, Patel et al. (1998) relataram que o caráter altura de planta foi predominantemente controlado por efeitos gênicos aditivos em pimenta.

\section{b) Número de dias para o florescimento}

O caráter número de dias para o florescimento mostrou-se controlado tanto por efeitos não-aditivos (Gill et al., 1973 em pimentão; Bhagyalakshmi et al., 1991 em pimenta) quanto por efeitos aditivos (Vallejo et al., $1997 \mathrm{em}$ pimentão). Ahmed et al. (1997) observaram em pimentão uma maior magnitude dos efeitos aditivos controlando o número de dias para o aparecimento do primeiro fruto.

\section{c) Número de dias para a maturidade}

Em pimentão, Gill et al. (1973) e Miranda (1987) encontraram, respectivamente, maiores magnitudes e maior predominância dos efeitos gênicos não-aditivos para a produção precoce. Em pimenta, maiores magnitudes (Ahmed et al., 1998) e maior predominância (Bhagyalakshmi et al., 1991 e Doshi \& Shukla, 2000c) das ações não-aditivas para o caráter dias para a maturidade dos frutos também foram encontradas; entretanto, Patel et 
al. (1998), relataram que o caráter dias para o amadurecimento dos frutos foi predominantemente controlado por efeito gênico aditivo.

\section{d) Produção total}

Em pimentão, Ado (1988) observou a participação tanto de efeitos aditivos como não-aditivos para o caráter produção total; Ahmed et al. (1994), Miranda (1987) e Tavares et al. (1997) relataram uma maior predominância dos efeitos gênicos não-aditivos para a produção total de frutos; Ahmed et al. (1997) e Gill et al. (1973) relataram terem encontrado efeitos não-aditivos de maiores magnitudes que os efeitos aditivos para o caráter produção total. Em pimenta, Ahmed et al. (1998) e Doshi \& Shukla (2000c) também encontraram magnitudes maiores das ações gênicas não-aditivas para produção; em contraste com estes resultados, Patel et al. (1998) e Gopalakrishnan et al. (1987) relataram que o caráter produção total de frutos foi predominantemente controlado por efeitos gênicos aditivos.

\section{e) Número de frutos por planta}

A maioria das pesquisas indicou que o número de frutos por planta é controlado principalmente por genes com efeitos aditivos, tanto em pimentão (Ahmed et al., 1997; Miranda, 1987; Tavares et al., 1997;Vallejo et al., 1997) quanto em pimenta (Ahmed et al., 1998; Doshi \& Shukla, 2000c; Gopalakrishnan et al., 1987; Patel et al., 1998). Evidências contrárias, ou seja, predominância de efeitos gênicos não-aditivos controlando o número de frutos por planta foram observados por alguns poucos autores : Gill et al. (1973) e Ahmed et al. (1994) em pimentão, assim como, Bhagyalakshmi et al. (1991) em pimenta.

\section{f) Peso médio de fruto}


Ahmed et al. (1994) verificaram que ambos os efeitos aditivos e nãoaditivos foram importantes para o caráter peso médio de fruto em pimentão; pórem, de maneira geral, há concordância entre os autores sobre a maior importância dos efeitos gênicos aditivos no controle desse caráter : Ahmed et al., 1997; Bem-Chaim \& Paran, 2000; Doshi \& Shukla, 2000b; Tavares et al., 1997; Vallejo et al., 1997 em pimentão e Ahmed et al., 1998; Doshi \& Shukla, 2000c; Gopalakrishnan et al., 1987; Patel et al., 1998 em pimenta. De forma contrária, Gill et al. (1973) encontraram maiores magnitudes dos efeitos nãoaditivos para tamanho de fruto em pimentão e Bhagyalakshmi et al. (1991) notaram em pimenta uma maior predominância da ação não-aditiva para peso médio de fruto.

\section{g) Comprimento de fruto}

Diversos autores relatam uma maior importância dos efeitos gênicos aditivos para o caráter comprimento de fruto, tanto em pimentão (Ahmed et al., 1994; Ahmed et al., 1997; Bem-Chaim \& Paran, 2000) como em pimenta (Doshi \& Shukla, 2000c; Gopalakrishnan et al., 1987; Patel et al., 1998). Por outro lado, Ahmed et al. (1998) encontraram em pimenta magnitudes maiores das ações gênicas não-aditivas para comprimento de fruto assim como Bhagyalakshmi et al. (1991) notaram também em pimenta uma maior predominância da ação não-aditiva para este caráter.

\section{h) Diâmetro de fruto}

Em pimentão, Ahmed et al. (1994) verificaram que ambos os efeitos aditivos e não-aditivos foram importantes para o caráter diâmetro de fruto. Bem-Chaim \& Paran (2000) encontraram em pimenta e pimentão, uma maior contribuição de efeitos gênicos aditivos para esse caráter. Em pimenta, a 
maioria dos trabalhos apontam para uma maior importância dos efeitos gênicos aditivos no controle do diâmetro de fruto : Ahmed et al. (1998); Gopalakrishnan et al. (1987); Patel et al. (1998); porém, Doshi \& Shukla (2000c) observaram ser a magnitude dos efeitos não-aditivos maior do que dos efeitos aditivos assim como também Bhagyalakshmi et al. (1991) notaram uma maior predominância da ação gênica não-aditiva para este caráter.

\section{i) Espessura de pericarpo de fruto}

Ahmed et al. (1997) observaram em pimentão uma maior magnitude dos efeitos aditivos para o caráter espessura de polpa de fruto. Da mesma forma Bem-Chaim \& Paran (2000) encontraram, tanto em pimenta como em pimentão, uma maior contribuição de efeitos gênicos aditivos para espessura de polpa. Ahmed et al. (1998) também encontraram em pimenta uma maior importância da ação gênica aditiva para espessura de polpa.

\section{j) Número de lóculos por fruto}

Miranda (1987) obteve em pimentão uma predominância de efeito gênico aditivo para o caráter número de lóculos por fruto.

\section{k) Herança dos caracteres em conjunto}

As divergências observadas entre os resultados encontrados pelos autores, no que diz respeito à natureza gênica dos caracteres estudados, provavelmente são devidas às diferenças entre os diversos conjuntos gênicos avaliados. A avaliação conjunta dos resultados obtidos pelos diferentes autores indica que, na maioria dos casos, a natureza gênica da maior parte dos caracteres envolvidos obedece a um modelo aditivo-dominante, onde para os caracteres altura de planta, número de dias para a maturidade e produção total 
de frutos predomina a dominância. Já para os caracteres número de frutos por planta, peso médio, comprimento, largura e espessura de pericarpo de fruto predomina a aditividade. 


\section{MATERIAL E MÉTODOS}

\subsection{Material genético}

Para a realização desta pesquisa, foram utilizados dez genitores de pimentão com frutos de colorações verde na fase imatura e vermelha na fase madura, originários do programa de pesquisa da Sakata Seed Sudamerica, divididos em dois grupos (1 e 2), segundo a origem e a reação ao PVY (Potato Virus Y ou Vírus Y da Batata) estirpe 1-2.

O grupo 1 é formado por quatro genitores (AF3267, AF3269, AF3270 e AF3278) com caracteres morfológicos (tanto de planta quanto de fruto) distintos , porém apresentando a mesma base genética original. Os mesmos foram desenvolvidos por meio de autofecundações sucessivas, a partir de uma população $\mathrm{RC}_{3}$ utilizando-se o método genealógico até se chegar a $\mathrm{RC}_{3} \mathrm{~S}_{9}$. Estes quatro genitores são resistentes ao PVY estirpe 1-2.

O grupo 2 é formado por seis genitores com caracteres morfológicos (tanto de planta quanto de fruto) divergentes e que foram obtidos por meio de autofecundações sucessivas de híbridos comerciais diferentes até $F_{9} / F_{10}$ (AF3248, AF3249, AF3252, AF3254, AF3255 e AF3256), utilizando-se o método genealógico. Estes seis genitores são suscetíveis ao PVY estirpe 1-2.

Como testemunha foi utilizado o híbrido comercial Magali-R.

Uma breve descrição morfológica desses dez genitores segue no Quadro 1 abaixo : 


\begin{tabular}{|c|c|c|l|l|l|l|l|l|}
\hline Grupo & $\mathrm{N}^{\mathrm{o}}$ & Genitor & $\begin{array}{l}\text { Altura } \\
\text { da } \\
\text { planta } \\
(\mathrm{cm})\end{array}$ & $\begin{array}{l}\text { Peso } \\
\text { do } \\
\text { fruto } \\
(\mathrm{g})\end{array}$ & $\begin{array}{l}\text { Compri } \\
\text { mento } \\
\text { do fruto } \\
(\mathrm{cm})\end{array}$ & $\begin{array}{l}\text { Diâme } \\
\text { tro do } \\
\text { fruto } \\
(\mathrm{cm})\end{array}$ & $\begin{array}{l}\text { Número } \\
\text { de } \\
\text { lóculos }\end{array}$ & $\begin{array}{l}\text { Espessura } \\
\text { de } \\
\text { pericarpo } \\
(\mathrm{mm})\end{array}$ \\
\hline 1 & 1 & AF3267 & $55-65$ & 175 & 15,5 & 7,5 & 3 e 4 & 5,0 \\
\hline 1 & 2 & AF3269 & $70-80$ & 185 & 14,0 & 8,0 & 3 e 4 & 5,5 \\
\hline 1 & 3 & AF3270 & $60-70$ & 190 & 15,0 & 7,5 & 3 e 4 & 5,0 \\
\hline 1 & 4 & AF3278 & $55-65$ & 175 & 13,5 & 8,0 & 3 e 4 & 5,5 \\
\hline 2 & 5 & AF3248 & $75-85$ & 180 & 14,0 & 8,0 & 3 e 4 & 6,0 \\
\hline 2 & 6 & AF3249 & $65-75$ & 165 & 13,5 & 7,5 & 3 e 4 & 5,5 \\
\hline 2 & 7 & AF3252 & $80-90$ & 190 & 19,0 & 8,0 & 3 e 4 & 6,0 \\
\hline 2 & 8 & AF3254 & $80-90$ & 160 & 11,5 & 8,5 & 3 e 4 & 5,0 \\
\hline 2 & 9 & AF3255 & $70-80$ & 170 & 14,0 & 7,5 & 3 e 4 & 5,5 \\
\hline 2 & 10 & AF3256 & $80-90$ & 150 & 16,0 & 7,5 & 3 e 4 & 6,0 \\
\hline
\end{tabular}

Quadro 1 - Descrição morfológica dos dez genitores envolvidos no dialelo parcial 4x6.

\subsection{Obtenção dos híbridos}

Os híbridos foram obtidos a partir de cruzamentos manuais controlados, seguindo-se o modelo de cruzamentos dialélicos parciais entre grupos, no qual os quatro genitores de um grupo foram cruzados com os seis genitores do outro grupo, obtendo-se um total de 24 híbridos $F_{1}$ (Tabela 1).

Os cruzamentos para a obtenção dos 24 híbridos foram realizados em condição de estufa, na Estação Experimental da Sakata Seed Sudamérica 
Tabela 1. Tabela dialélica 4x6 com os dez genitores utilizados e os 24 híbridos resultantes.

\begin{tabular}{|c|c|c|c|c|c|c|c|c|}
\hline & & & Grupo 2 : Lint & Genitoras $\varsigma$ & veis ao PVY & $1-2$ & & \\
\hline & macho & & $\begin{array}{c}\text { Genitor } 5 \\
\text { AF3248 }\end{array}$ & $\begin{array}{l}\text { Genitor } 6 \\
\text { AF3249 }\end{array}$ & $\begin{array}{c}\text { Genitor } 7 \\
\text { AF3252 }\end{array}$ & $\begin{array}{l}\text { Genitor } 8 \\
\text { AF3254 }\end{array}$ & $\begin{array}{l}\text { Genitor } 9 \\
\text { AF3255 }\end{array}$ & $\begin{array}{c}\text { Genitor } 10 \\
\text { AF3256 }\end{array}$ \\
\hline Grupo 1: & Genitor 1 & AF3267 & $5 \times 1$ & $6 \times 1$ & $7 \times 1$ & $8 \times 1$ & $9 \times 1$ & $10 \times 1$ \\
\hline Linhagens & Genitor 2 & AF3269 & $5 \times 2$ & $6 \times 2$ & $7 \times 2$ & $8 \times 2$ & $9 \times 2$ & $10 \times 2$ \\
\hline Genitoras & Genitor 3 & AF3270 & $5 \times 3$ & $6 \times 3$ & $7 \times 3$ & $8 \times 3$ & $9 \times 3$ & $10 \times 3$ \\
\hline $\begin{array}{l}\text { Resistentes } \\
\text { ao PVY }\end{array}$ & Genitor 4 & AF3278 & $5 \times 4$ & $6 \times 4$ & $7 \times 4$ & $8 \times 4$ & $9 \times 4$ & $10 \times 4$ \\
\hline
\end{tabular}

Grupo 1 ( 1 a 4 ) : Retrocruzamentos entre Genitor Recorrente e Genitor Doador :

$$
1,2,3:\left(\mathrm{GR}^{4} \times \mathrm{GD}\right) \mathrm{F}_{9: 7} \text { e } 4:\left(\mathrm{GR}^{4} \times \mathrm{GD}\right) \mathrm{F}_{9}
$$

Grupo 2 ( 5 a 10 ) : Linhagens genitoras obtidas de híbridos comerciais distintos :

5 e $6: F_{10}$ e $7,8,9,10: F_{9}$ 
Ltda, localizada no municipio de Bragança Paulista-SP (latitude $23^{0} \mathrm{~S}$, longitude $47^{0} \mathrm{~W}$ e altitude de $850 \mathrm{~m}$ ).

As atividades relacionadas à obtenção dos 24 híbridos foram desenvolvidas no período de julho de 1998 a abril de 1999.

Os botões florais das plantas dos seis genitores utilizados como fêmeas foram emasculados pela manhã, utilizando-se uma pinça. Os estigmas dos mesmos foram polinizados, no mesmo período, esfregando-se os grãos de pólen das anteras colhidas das flores dos quatro genitores utilizados como machos.

Os frutos oriundos dos cruzamentos realizados foram colhidos maduros e as sementes $\mathrm{F}_{1}$ foram extraídas manualmente, tratadas com $\mathrm{NaOH}$, enxaguadas, secas à sombra e armazenadas em ambiente com temperatura de $20^{\circ}$ Celsius e $35 \%$ de umidade relativa do ar.

\subsection{Delineamento experimental}

O experimento para a avaliação dos 24 híbridos $F_{1}$, dos dez genitores e da testemunha (híbrido comercial) foi instalado em campo experimental a céu aberto na Estação Experimental da Sakata Seed Sudamérica Ltda, localizada no município de Bragança Paulista-SP (latitude $23^{0} \mathrm{~S}$, longitude $47^{0} \mathrm{~W}$ e altitude de $850 \mathrm{~m}$ ). Utilizou-se o delineamento em blocos casualizados completos, com 35 tratamentos em quatro repetições. Cada parcela experimental foi constituída de dez plantas; a área útil compreendeu cinco plantas competitivas, dispostas em fileira única. A área experimental constou de 27 canteiros com $0,20 \mathrm{~m}$ de altura, $1,00 \mathrm{~m}$ de largura, 50,0m de comprimento; o espaçamento foi de $1,40 \mathrm{~m}$ entre centros de canteiros e $0,50 \mathrm{~m}$ entre plantas dentro de canteiros. As bordaduras foram compostas por dois 
canteiros em cada lateral da área experimental e mais três plantas no início e no final de cada canteiro. Toda a área experimental foi contornada com tela de tecido anti-vírus para isolamento contra eventuais insetos vetores de virose, como por exemplo tripes e pulgões.

A semeadura foi realizada em 16/09/99 em bandejas de poliestireno expandido de 128 células, utilizando-se substrato comercial, com posterior transplante para o campo. Foram feitas adubações de cobertura com produtos altamente solúveis em água, em dias alternados, após a emissão do primeiro par de folhas verdadeiras.

A calagem e a adubação de plantio foram feitas no sentido de corrigir os desvios apresentados pela análise de solo realizada anteriormente ao plantio. Para tanto, utilizou-se $1.400 \mathrm{Kg} / \mathrm{ha}$ de calcário PRNT 180, $668 \mathrm{Kg} / \mathrm{ha}$ de Superfosfato Triplo, $680 \mathrm{Kg} / \mathrm{ha}$ de Nitrato de Potássio, $30 \mathrm{Kg} / \mathrm{ha}$ de Ácido Bórico, $20 \mathrm{Kg} / \mathrm{ha}$ de Sulfato de Zinco e cerca de 10 toneladas de composto orgânico, todos distribuídos no sulco de plantio.

O transplante das mudas para o campo experimental foi realizado em 18/10/99, deixando-se a princípio duas mudas por cova até o pronto estabelecimento das mesmas, sendo em seguida feito o desbaste para uma muda por cova, garantindo desta forma um completo estande inicial.

As adubações de cobertura foram realizadas em dias alternados, utilizando-se quantidades específicas de nutrientes demandadas pela planta em cada uma de suas fases de desenvolvimento. Para tanto foram utilizadas formulações altamente solúveis via fertirrigação, por gotejamento, em canteiros cobertos por plástico dupla face (preto/cinza).

As plantas foram tutoradas individualmente em hastes de bambu, na vertical, sendo presas às mesmas por fio de sisal. 
Realizou-se a retirada dos brotos laterais até a primeira bifurcação bem como a flor desta, pois a retirada da flor da primeira bifurcação é uma prática comum entre muitos produtores, que buscam com isso, não retardar e também não diminuir o desenvolvimento dos frutos subsequentes.

Foram realizadas pulverizações semanais preventivas de defensivos para o controle de pragas e doenças que mais comumente atacam o pimentão.

Realizaram-se quatro colheitas (uma a cada 15 dias em média), sendo a primeira em 24/01/2000 e a última em 17/03/2000, totalizando 7 meses de ciclo. Os frutos foram colhidos desde a fase de coloração verde final (ponto comercial) até o início do aparecimento da coloração vermelha.

\subsection{Avaliação dos caracteres estudados}

As avaliações foram realizadas utilizando-se cinco plantas, de um total de dez, em cada parcela. Os critérios utilizados para a escolha das cinco plantas foram dois : a planta selecionada deveria estar sadia e sofrendo competição de plantas vizinhas de ambos os lados. As cinco plantas foram escolhidas na véspera da primeira colheita. Os dados foram tomados individualmente, ou seja, por planta. Para a utilização dos dados nas análises, calculou-se o valor médio por planta ou por fruto, dependendo do caráter. Os seguintes caracteres foram avaliados :

a) Altura da planta na maturidade (APM) - Anotou-se a altura de cada uma das 5 plantas da área útil da parcela, calculando-se posteriormente, a média. Este parâmetro foi obtido no amadurecimento dos frutos, medindo-se a distância, em centímetros, entre o nível do solo e a parte mais alta da planta. 
b) Número de dias para o florescimento (NDF) - Anotou-se o número de dias decorridos da semeadura até a abertura da segunda flor, uma vez que a primeira flor foi eliminada. Tomou-se como base a abertura da flor em no mínimo 50\% das plantas úteis da parcela.

c) Número de dias para a maturidade (NDM) - Anotou-se o número de dias decorridos da semeadura até a mudança de coloração dos frutos de verde para vermelho. Tomou-se como base a mudança na coloração dos frutos em no mínimo 50\% das plantas.

d) Produção de frutos por planta (PFP) - Anotou-se o peso dos frutos em cada uma das cinco plantas e calculou-se a média, obtendo-se a produção total média por planta.

e) Número de frutos produzidos por planta (NFP) - Contou-se o número de frutos em cada planta, em cada uma das cinco plantas e calculou-se a média, obtendo-se o número total médio de frutos por planta.

f) Peso médio de fruto (PMF) - Foi obtido através da divisão do valor da produção total de frutos pelo número total de frutos das cinco plantas, considerando as quatro colheitas realizadas.

g) Comprimento de fruto (CF) - Fez-se uma amostragem, utilizando-se 20 frutos de cada parcela útil, na primeira colheita. 
h) Diâmetro de fruto (DF) - Utilizou-se amostragem semelhante à do item anterior. Este parâmetro foi obtido medindo-se a largura do fruto na sua posição mais próxima da cicatriz peduncular.

i) Espessura de pericarpo de fruto (EP) - A mesma amostragem do item anterior foi utilizada, onde os frutos foram cortados ao meio e tiveram as suas paredes medidas com paquímetro. $\mathrm{O}$ valor foi obtido de uma das paredes de uma das metades do fruto.

j) Número de lóculos por fruto (NL) - Contou-se o número de lóculos dos frutos amostrados no item anterior, cortando-os transversalmente.

\subsection{Análises genético-estatísticas}

\subsubsection{Análise de variância}

A análise de variância (ANAVA) foi realizada segundo o esquema contido na Tabela 2, considerando o seguinte modelo estatístico :

$$
Y_{i j}=\boldsymbol{\mu}+t_{i}+b_{j}+e_{i j}
$$

sendo

$$
\mathrm{Y}_{\mathrm{ij}} \text { : observação do i-ésimo genótipo no j-ésimo bloco ; }
$$

$\boldsymbol{\mu}$ : média geral da população ;

$\mathrm{t}_{\mathbf{i}}$ : efeito do i-ésimo genótipo (tratamento);

$b_{\mathbf{j}}$ : efeito do j-ésimo bloco (repetição) ;

$\mathrm{e}_{\mathrm{ij}}$ : efeito do erro experimental.

Tabela 2. Esquema da ANAVA, apresentando as esperanças dos quadrados 
médios para cada um dos dez caracteres avaliados, no delineamento blocos casualizados.

\begin{tabular}{lllll}
\hline Fontes de variação & $\mathrm{GL}$ & $\mathrm{QM}$ & $\mathrm{E}(\mathrm{QM})$ & $\mathrm{F}$ \\
\hline tratamentos & $\mathrm{t}-1$ & $\mathrm{QM}_{1}$ & $\boldsymbol{\sigma}_{\mathrm{e}}{ }^{2}+\mathrm{V}_{\mathrm{g}}$ & $\mathrm{QM}_{\mathbf{1}} / \mathrm{QM}_{3}$ \\
blocos & $\mathrm{r}-1$ & $\mathrm{QM}_{2}$ & --- & --- \\
erro & $(\mathrm{t}-1)(\mathrm{r}-1)$ & $\mathrm{QM}_{3}$ & $\boldsymbol{\sigma}_{\mathrm{e}}{ }^{2}$ & \\
\hline
\end{tabular}

sendo :

$\mathrm{t}:$ número de tratamentos (genótipos) $=34$;

$\mathrm{r}:$ número de repetições $=4$;

$\mathrm{V}_{\mathrm{g}}$ : componente de variância genética entre tratamentos ;

$\boldsymbol{\sigma}_{\mathrm{e}}{ }^{2}$ : componente de variância do erro experimental.

As estimativas dos parâmetros genéticos foram calculadas através das seguintes fórmulas :

a) Variância ambiental $\left(\boldsymbol{\sigma}_{\mathrm{e}}{ }^{2}\right)$ :

$$
\sigma_{\mathrm{e}}^{2}=\mathrm{QM}_{3}
$$

b) Coeficiente de variação genética (CV) :

$$
\mathrm{CV}=\left(\boldsymbol{\sigma}_{\mathrm{e}} / \mathrm{m}\right) 100
$$

onde

$\boldsymbol{\sigma}_{\mathrm{e}}:$ estimativa do desvio-padrão ambiental ;

$\mathrm{m}$ : média do caráter.

\subsubsection{Análise dialélica}


A análise de variância (ANAVA) foi realizada segundo o esquema contido na Tabela 3, utilizando-se o programa GENES (2001). Os dados experimentais foram avaliados pelo Modelo de Gardner \& Eberhart (1966) adaptado por Miranda Filho \& Geraldi (1984) para o estudo da heterose em dialelos parciais que envolvem dois grupos de genitores e suas respectivas combinações híbridas. Por meio desta metodologia, a soma de quadrados de tratamentos é decomposta em somas de quadrados associadas aos efeitos entre grupos de genitores (G1 e G2), ao da heterose e ao do contraste G1 vs G2. Também foi feito um detalhamento da heterose manifestada nos híbridos, decompondo sua soma de quadrados em heterose média, heterose atribuída aos vários genótipos dentro de cada grupo e heterose específica, de acordo com o modelo estatístico-genético:

$$
Y_{i j}=\mu+1 / 2\left(v_{i}+v_{j}\right)+h+h_{i}+h_{j}+s_{i j}+e_{i j}
$$

Sendo :

$\mathbf{Y}_{\mathbf{i j}}$ : observação da parcela representada pelo genótipo $\mathbf{i}$ no bloco $\mathbf{j}$;

i : $0,1, \ldots, p(p=$ número de genitores do grupo 1$)$;

j : $0,1, \ldots, \mathrm{q}(\mathrm{q}=$ número de genitores do grupo 2$)$;

$\boldsymbol{\mu}:$ média geral da população);

$\mathbf{v}_{\mathbf{i}}$ : efeito do i-ésimo genitor do grupo 1 ;

$\mathbf{v}_{\mathbf{j}}$ : efeito do j-ésimo genitor do grupo 2 ;

$\mathbf{h}$ : efeito da heterose média ;

$\mathbf{h}_{\mathbf{i}}$ : efeito da heterose atribuído ao i-ésimo genitor do grupo 1 ;

$\mathbf{h}_{\mathbf{j}}$ : efeito da heterose atribuído ao j-ésimo genitor do grupo 2 ; 
$\mathbf{s}_{\mathbf{i j}}$ : efeito da heterose específica resultante do cruzamento entre genitores de ordem i e $\mathbf{j}$, dos grupos 1 e 2 , respectivamente.

$\mathbf{e}_{\mathbf{i j}}$ : erro experimental médio.

Tabela 3. Esquema da ANAVA para um dialelo parcial, apresentando os desdobramentos dos tratamentos em grupos de genitores e da heterose em heterose média, de grupos e específica.

\begin{tabular}{llll}
\hline Fontes de variação & $\mathrm{GL}$ & $\mathrm{QM}$ & $\mathrm{F}$ \\
\hline tratamentos & $\mathrm{pq}+\mathrm{p}+\mathrm{q}-1$ & $\mathrm{QM}_{1}$ & $\mathrm{QM}_{1} / \mathrm{QM}_{10}$ \\
grupo 1 & $\mathrm{p}-1$ & $\mathrm{QM}_{2}$ & $\mathrm{QM}_{2} / \mathrm{QM}_{10}$ \\
grupo 2 & $\mathrm{q}-1$ & $\mathrm{QM}_{3}$ & $\mathrm{QM}_{3} / \mathrm{QM}_{10}$ \\
grupo 1 vs grupo 2 & 1 & $\mathrm{QM}_{4}$ & $\mathrm{QM}_{4} / \mathrm{QM}_{10}$ \\
heterose & $\mathrm{pq}$ & $\mathrm{QM}_{5}$ & $\mathrm{QM}_{5} / \mathrm{QM}_{10}$ \\
heterose média & 1 & $\mathrm{QM}_{6}$ & $\mathrm{QM}_{6} / \mathrm{QM}_{10}$ \\
heterose do grupo 1 & $\mathrm{p}-1$ & $\mathrm{QM}_{7}$ & $\mathrm{QM}_{7} / \mathrm{QM}_{10}$ \\
heterose do grupo 2 & $\mathrm{q}-1$ & $\mathrm{QM}_{\mathbf{8}}$ & $\mathrm{QM}_{8} / \mathrm{QM}_{10}$ \\
heterose específica & $(\mathrm{p}-1)(\mathrm{q}-1)$ & $\mathrm{QM}_{9}$ & $\mathrm{QM}_{9} / \mathrm{QM}_{10}$ \\
erro & $\mathrm{m}$ & $\mathrm{QM}_{10}$ & - \\
\hline
\end{tabular}

sendo :

p : número de genitores do grupo 1 ;

$\mathrm{q}$ : número de genitores do grupo 2 ;

$\mathrm{m}$ : número de graus de liberdade associado ao resíduo.

As estimativas dos parâmetros genéticos foram calculadas através das seguintes fórmulas : 
a) $\boldsymbol{\mu}$ : média geral da população $=\left(q \mathrm{Y}_{(1)}+\mathrm{pY} \mathrm{Y}_{(2)}\right) / 2 \mathrm{pq}$;

b) $\mathrm{h}$ : heterose média $=\mathrm{Y}_{\mathrm{H}} / \mathrm{pq}-\left(\mathrm{qY}_{(1)+} \mathrm{pY}(2)\right) / 2 \mathrm{pq}$;

c) $\mathrm{v}_{\mathrm{i}}$ : efeito varietal de cada um dos genitores do grupo $1=\mathrm{Y}_{\mathrm{iO}}-\mathrm{Y}_{(1)} / \mathrm{p}$;

d) $\mathrm{v}_{\mathrm{j}}$ : efeito varietal de cada um dos genitores do grupo $2=\mathrm{Y}_{\mathrm{Oj}^{-}} \mathrm{Y}_{(2)} / \mathrm{p}$;

e) $\mathrm{h}_{\mathrm{i}}$ : efeito heterótico de cada um dos genitores do grupo $1: \mathrm{Y}_{\mathrm{i} .} / \mathrm{q}$ $\mathrm{Y}_{\mathrm{H}} / \mathrm{pq}+1 / 2\left[\mathrm{Y}_{(1)} / \mathrm{p}-\mathrm{Y}_{\mathrm{iO}}\right]$

f) $h_{j}$ : efeito heterótico de cada um dos genitores do grupo $2=Y_{. j} / p$ $\mathrm{Y}_{\mathrm{H}} / \mathrm{pq}+1 / 2\left[\mathrm{Y}_{(2)} / \mathrm{q}-\mathrm{Y}_{\mathrm{Oj}}\right]$

g) $\mathrm{s}_{\mathrm{ij}}$ : efeito da heterose específica resultante do cruzamento entre genitores de grupos diferentes $=\mathrm{Y}_{\mathrm{ij}}+\mathrm{Y}_{\mathrm{H}} / \mathrm{pq}-\mathrm{Y}_{\mathrm{i} .} / \mathrm{q}-\mathrm{Y}_{\mathrm{j}} / \mathrm{p}$

onde :

$\mathrm{Y}_{\mathrm{ij}}$ : valores observados das pq combinações ;

$\mathrm{Y}_{\mathrm{T}}$ : total geral que inclui as pq combinações híbridas e os $\mathrm{p}+\mathrm{q}$ genitores ;

$\mathrm{Y}_{\mathrm{H}}$ : total das pq combinações híbridas ;

$\mathrm{Y}_{(1)}$ : total das $\mathrm{p}$ médias dos genitores do grupo 1 ;

$\mathrm{Y}_{(2)}$ : total das q médias dos genitores do grupo 2 ;

$\mathrm{Y}_{\mathrm{i} .}$ : total das q combinações híbridas do i-ésimo genitor do grupo 1 ;

$\mathrm{Y}_{\mathrm{j}}$ : total das $\mathrm{p}$ combinações híbridas do j-ésimo genitor do grupo 2 ;

$\mathrm{Y}_{\mathrm{iO}}$ : valor observado dos $\mathrm{p}$ genitores ;

$\mathrm{Y}_{\mathrm{Oj}}$ : valor observado dos q genitores .

\subsubsection{Heterose}

Foram calculados os valores de heterose dos 24 híbridos em relação à média dos genitores, em relação ao genitor resistente ao PVY, em relação ao 
genitor suscetível ao PVY e em relação ao híbrido-padrão Magali-R, atualmente líder no mercado brasileiro de pimentão verde. Para tanto foram utilizadas as seguintes fórmulas :

$$
\begin{aligned}
& \mathrm{H}_{\mathrm{MG}}=\mathrm{F}_{1}-(1 / 2 \mathrm{G} 1+1 / 2 \mathrm{G} 2) \text { e }\left[\mathrm{F}_{1} /(1 / 2 \mathrm{G} 1+1 / 2 \mathrm{G} 2)\right] 100 ; \\
& \mathrm{H}_{\mathrm{GRPVY}}=\mathrm{F}_{1}-\mathrm{GRPVY} \text { e }\left(\mathrm{F}_{1} / \mathrm{GRPVY}\right) 100 ; \\
& \mathrm{H}_{\mathrm{GSPVY}}=\mathrm{F}_{1}-\mathrm{GSPVY} \text { e }\left(\mathrm{F}_{1} / \mathrm{GSPVY}\right) 100 ; \\
& \mathrm{H}_{\mathrm{HP}}=\mathrm{F}_{1}-\mathrm{HP} \text { e }\left(\mathrm{F}_{1} / \mathrm{HP}\right) 100
\end{aligned}
$$

Onde :

$\mathrm{H}_{\mathrm{MG}}$ : heterose em relação à média dos genitores, expressa em valor absoluto e porcentagem $(\mathrm{MG}=100 \%)$, respectivamente ;

$\mathrm{H}_{\mathrm{GRPVY}}$ : heterose em relação ao genitor resistente ao PVY, expressa em valor absoluto e porcentagem (GRPVY $=100 \%)$, respectivamente ;

$\mathrm{H}_{\mathrm{GSPVY}}$ : heterose em relação ao genitor suscetível ao PVY, expressa em valor absoluto e porcentagem (GSPVY $=100 \%)$, respectivamente ;

$\mathrm{H}_{\mathrm{HP}}$ : heterose em relação ao híbrido-padrão, expressa em valor absoluto e porcentagem $(\mathrm{HP}=100 \%)$, respectivamente ;

F1 : média do caráter para cada híbrido ;

G1 : média do caráter no genitor do grupo 1 ;

G2 : média do caráter no genitor do grupo 2 ;

GRPVY : média do caráter no genitor resistente ao PVY ;

GSPVY : média do caráter no genitor suscetível ao PVY ; 
HP : média do caráter no híbrido-padrão.

\subsubsection{Testes de significância}

a) Teste F para cada um dos dez caracteres avaliados, com o intuito de comparar as suas variâncias ;

b) Teste de Scott-Knott para contrastar as médias dos tratamentos entre si;

c) Teste de Dunnet para contrastar as médias dos tratamentos com a média do híbrido-padrão Magali-R ;

d) Teste t para contrastar as médias dos híbridos com as médias dos seus respectivos genitores e com o valor médio dos genitores. 


\section{RESULTADOS E DISCUSSÃO}

\subsection{Análises de variância}

O resumo da análise de variância dos dados é apresentado na Tabela 4. Nela estão os valores e as respectivas significâncias dos quadrados médios assim como os valores dos coeficientes de variação (C.V.\%) e das médias para os dez caracteres avaliados.

$\mathrm{Na}$ Tabela 5 é apresentada a análise de variância com o desdobramento dos quadrados médios dos genótipos em grupo 1 versus grupo 2, grupo 1, grupo 2 e heterose, bem como o desdobramento da heterose em heterose média, heterose do grupo 1, heterose do grupo 2 e heterose específica, juntamente com as suas respectivas significâncias.

Os quadrados médios para genótipos foram significativos a 5\% pelo teste $\mathrm{F}$ para todos os caracteres, evidenciando que os tratamentos são geneticamente contrastantes.

A análise de variância revela que dentro do grupo 1 há diferença significativa entre os quatro genitores envolvidos, para todos os caracteres avaliados, exceto número de dias para florescimento. Já no grupo 2 , houve diferença significativa para todos os caracteres avaliados entre os seis genitores participantes.

Para o contraste grupo 1 versus grupo 2, a análise de variância revelou haver diferença significativa para os caracteres APM, NDF, PFP, NFP, PMF, EP e NL, comprovando estarem presentes diferenças tanto para caracteres de planta como para caracteres de fruto entre os dois grupos. 
Tabela 4. Valores e significâncias dos quadrados médios, médias e coeficientes de variação da análise de variância, com base na média da parcela para os dez caracteres avaliados.

\begin{tabular}{|c|c|c|c|c|c|c|c|c|c|c|c|}
\hline \multirow[b]{2}{*}{ F.V. } & \multirow[b]{2}{*}{ G.L. } & \multicolumn{9}{|c|}{ Caracteres } & \multirow[b]{2}{*}{$\begin{array}{c}\mathrm{NL} \\
\text { número }\end{array}$} \\
\hline & & $\begin{array}{c}\text { APM } \\
\mathrm{cm}\end{array}$ & $\begin{array}{l}\text { NDF } \\
\text { dias }\end{array}$ & $\begin{array}{l}\text { NDM } \\
\text { dias }\end{array}$ & $\begin{array}{c}\text { PFP } \\
\mathrm{Kg}\end{array}$ & $\begin{array}{c}\text { NFP } \\
\text { número }\end{array}$ & $\begin{array}{c}\text { PMF } \\
\text { gramas }\end{array}$ & $\begin{array}{l}\mathrm{CF} \\
\mathrm{cm}\end{array}$ & $\begin{array}{l}\mathrm{DF} \\
\mathrm{cm}\end{array}$ & $\begin{array}{l}\mathrm{EP} \\
\mathrm{mm}\end{array}$ & \\
\hline Blocos & 3 & 47,89 & 7,97 & 23,93 & 0,27 & 22,54 & 927,24 & 0,97 & 0,18 & 0,37 & 0,08 \\
\hline Genótipos & 33 & $248,21^{*}$ & $10,40^{*}$ & $13,75^{\star}$ & $0,81^{*}$ & $30,48^{*}$ & $667,26^{*}$ & $14,31^{*}$ & $0,47^{*}$ & $0,45^{\star}$ & $0,16^{*}$ \\
\hline Resíduo & 99 & 21,15 & 6,00 & 3,47 & 0,28 & 9,56 & 83,62 & 0,64 & 0,12 & 0,23 & 0,06 \\
\hline Média & & 71,60 & 98,27 & 156,43 & 4,32 & 24,06 & 180,64 & 15,20 & 7,72 & 5,48 & 3,52 \\
\hline C.V.(\%) & & 12,27 & 2,71 & 1,62 & 14,86 & 16,08 & 8,66 & 13,13 & 5,93 & 9,76 & 8,40 \\
\hline
\end{tabular}

* Significativo a 5\% pelo Teste $\mathrm{F}$

APM : Altura da planta na maturidade

NDF : Número de dias para o florescimento

NDM : Número de dias para a maturidade

PFP : Produção de frutos por planta

NFP : Número de frutos produzidos por planta

PMF : Peso médio de fruto

$\mathrm{CF}$ : Comprimento de fruto

DF : Diâmetro de fruto

EP : Espessura de pericarpo de fruto

NL : número de lóculos por fruto 
Tabela 5. Quadrados médios e significâncias, com os genótipos desdobrados em grupos (G1 e G2) e a heterose desdobrada em heterose média $(\mathrm{h})$, de grupos $\left(\mathrm{h}_{\mathrm{G} 1}, \mathrm{~h}_{\mathrm{G} 2}\right)$ e específica $\left(\mathrm{h}_{\mathrm{e}}\right)$ para os dez caracteres avaliados.

\begin{tabular}{|c|c|c|c|c|c|c|c|c|c|c|c|}
\hline \multirow{3}{*}{ F.V. } & \multirow{3}{*}{ G.L. } & & \multicolumn{9}{|c|}{ Caracteres } \\
\hline & & APM & NDF & NDM & PFP & NFP & PMF & CF & DF & EP & $\mathrm{NL}$ \\
\hline & & $\mathrm{cm}$ & dias & dias & $\mathrm{Kg}$ & número & gramas & $\mathrm{cm}$ & $\mathrm{cm}$ & $\mathrm{mm}$ & número \\
\hline Genótipos & 33 & $62,05^{*}$ & $2,61^{*}$ & $3,42^{*}$ & $0,20^{*}$ & $7,62^{*}$ & $166,79^{*}$ & $3,58^{*}$ & $0,12^{*}$ & $0,11^{*}$ & $0,04^{*}$ \\
\hline G1 vs G2 & 1 & $620,29^{*}$ & $8,99^{\star}$ & $0,12 \mathrm{~ns}$ & $1,53^{*}$ & $102,53^{*}$ & $468,80^{*}$ & $0,05 \mathrm{~ns}$ & $0,00 \mathrm{~ns}$ & $0,49^{*}$ & $0,20^{*}$ \\
\hline G1 & 3 & $126,22^{*}$ & $0,57 \mathrm{~ns}$ & $6,54^{*}$ & $0,59^{*}$ & $26,11^{*}$ & $87,67^{*}$ & $2,10^{*}$ & $0,42^{*}$ & $0,17^{\star}$ & $0,05^{\star}$ \\
\hline G2 & 5 & $139,97^{*}$ & $6,23^{*}$ & $12,93^{*}$ & $0,36^{*}$ & $5,58^{\star}$ & $546,98^{*}$ & $16,16^{*}$ & $0,30^{*}$ & $0,34^{*}$ & $0,13^{*}$ \\
\hline Heterose & 24 & $14,54^{*}$ & $1,85 \mathrm{~ns}$ & $1,18 \mathrm{~ns}$ & $0,07 \mathrm{~ns}$ & $1,78 \mathrm{~ns}$ & $84,88^{*}$ & $1,28^{*}$ & $0,05 n s$ & $0,04 \mathrm{~ns}$ & $0,01 \mathrm{~ns}$ \\
\hline $\mathrm{h}$ & 1 & $72,43^{\star}$ & $2,09 \mathrm{~ns}$ & $3,24 \mathrm{~ns}$ & $0,08 \mathrm{~ns}$ & 0,78 ns & $283,91^{*}$ & $4,69^{*}$ & $0,04 \mathrm{~ns}$ & $0,00 \mathrm{~ns}$ & $0,03 \mathrm{~ns}$ \\
\hline $\mathrm{h}_{\mathrm{G} 1}$ & 3 & $12,51 \mathrm{~ns}$ & $2,71 \mathrm{~ns}$ & $0,99 \mathrm{~ns}$ & $0,06 n s$ & $0,66 n s$ & $46,34 \mathrm{~ns}$ & $0,16 \mathrm{~ns}$ & $0,06 \mathrm{~ns}$ & $0,02 n s$ & $0,00 \mathrm{~ns}$ \\
\hline $\mathrm{h}_{\mathrm{G} 2}$ & 5 & $13,91^{*}$ & $1,72 \mathrm{~ns}$ & $1,85 \mathrm{~ns}$ & $0,11 \mathrm{~ns}$ & $3,16 \mathrm{~ns}$ & $93,38^{*}$ & $2,07^{\star}$ & $0,03 \mathrm{~ns}$ & $0,07 \mathrm{~ns}$ & $0,02 n s$ \\
\hline$h_{e}$ & 15 & $11,29^{*}$ & $1,71 \mathrm{~ns}$ & $0,86 \mathrm{~ns}$ & $0,06 n s$ & $1,60 \mathrm{~ns}$ & $76,49^{\star}$ & $1,02^{*}$ & $0,05 \mathrm{~ns}$ & $0,04 \mathrm{~ns}$ & $0,01 \mathrm{~ns}$ \\
\hline Resíduo & 99 & 5,29 & 1,50 & 0,87 & 0,07 & 2,39 & 20,9 & 0,16 & 0,03 & 0,06 & 0,02 \\
\hline
\end{tabular}

* Significativo a $5 \%$ pelo Teste $\mathrm{F}$ 
A análise de variância mostra ainda significância para heterose com relação aos caracteres APM, PMF e CF. Nestes três casos, houve significância para a participação da heterose média, heterose do grupo 2 e heterose específica, não existindo, portanto, influência da heterose do grupo 1 .

Os coeficientes de variação (C.V.\%) apresentaram valores de baixos $(1,62 \%)$ a médios $(16,08 \%)$ para os diferentes caracteres, o que para experimentos realizados a campo aberto são considerados aceitáveis. Com isso, fica comprovada a eficiência da utilização de parcelas com dez plantas totais e a escolha de cinco plantas úteis para a realização da tomada de dados. Da mesma forma, ficou comprovada a eficiência na amostragem realizada para a avaliação dos caracteres de fruto (PM, CF, DF, EP e NL).

Portanto, com quadrados médios significativos e coeficientes de variação baixos e médios há indicação de que houve variação genética entre os tratamentos, o que torna possível a obtenção de estimativas dos parâmetros genéticos com uma precisão satisfatória.

\subsection{Avaliação dos híbridos e da heterose}

\subsubsection{Altura da planta na maturidade}

Vários fatores estão envolvidos na definição da utilização de uma cultivar de porte baixo ou alto. Entre eles estão as condições edafo-climáticas (fertilidade do solo, temperatura, luminosidade, pluviosidade), manejo (fertilização, irrigação, espaçamento, tutoramento, desbrotas, controle de pragas e doenças), cultura local de produção, custo de produção local, período de produção desejado. É importante esclarecer que nem sempre cultivares com plantas de menor porte serão menos produtivas, pois existem cultivares que 
possuem plantas mais compactas, ou seja, plantas baixas tão produtivas quanto as plantas altas.

O teste de Scott-Knott, indicou a separação dos tratamentos em quatro diferentes grupos (Tabela 6). $\mathrm{O}$ híbrido $7 \times 2$ foi o que apresentou a maior altura de planta na maturidade (APM) $\mathrm{com} 82,50 \mathrm{~cm}$ ao passo que o de menor altura foi o híbrido $6 \times 3(59,50 \mathrm{~cm})$. A APM do híbrido-padrão (HP) Magali-R foi de $77,25 \mathrm{~cm}$, não diferindo estatisticamente do híbrido $7 \times 2$ pelo teste de Dunnett (Tabela 7).

De maneira geral, os híbridos apresentaram valores significativos de heterose negativa em relação à média dos genitores $(\mathrm{MG})$, variando de $-5,78$ a $-13,61 \%$, com apenas o híbrido $7 \times 4$ apresentando heterose significativamente positiva de 7,15\% (Tabela 8). Gopalakrishnan et al. (1987) também encontraram em pimenta heterose de $7,68 \%$ para altura de planta.

Houve a manifestação de heterose significativamente positiva (de 9,29 a 35,84\%) para diversos híbridos em relação aos genitores resistentes ao PVY (GRPVY), com exceção dos híbridos 5x2, 6x2, 9x2 e 6x3, os quais apresentaram significativa heterose negativa para APM (Tabela 8).

A maioria dos híbridos apresentaram valores significativos de heterose negativa (de $-5,69$ a -24,85\%) em relação aos genitores suscetíveis ao PVY (GSPVY), Tabela 8.

Muitos dos híbridos apresentaram heterose negativa significativa em relação ao HP Magali-R , variando de -12,62 a -22,98\% (Tabela 8). 
Tabela 6. Comparação entre médias: Teste de Scott Knott para médias de quatro repetições de dez caracteres avaliados.

\begin{tabular}{|c|c|c|c|c|c|c|c|c|c|c|c|c|c|c|c|c|c|c|c|}
\hline \multicolumn{2}{|c|}{$\begin{array}{l}\text { APM } \\
(\mathrm{cm})\end{array}$} & \multicolumn{2}{|c|}{$\begin{array}{l}\text { NDF } \\
\text { (dias) }\end{array}$} & \multicolumn{2}{|c|}{$\begin{array}{l}\text { NDM } \\
\text { (dias) }\end{array}$} & \multicolumn{2}{|c|}{$\begin{array}{l}\text { PFP } \\
(\mathrm{Kg})\end{array}$} & \multicolumn{2}{|c|}{$\begin{array}{c}\text { NFP } \\
\text { (número) }\end{array}$} & \multicolumn{2}{|c|}{$\begin{array}{c}\text { PMF } \\
\text { (gramas) }\end{array}$} & \multicolumn{2}{|l|}{$\begin{array}{l}\mathrm{CF} \\
(\mathrm{cm})\end{array}$} & \multicolumn{2}{|c|}{$\begin{array}{l}\mathrm{DF} \\
(\mathrm{cm})\end{array}$} & \multicolumn{2}{|c|}{$\begin{array}{l}\text { EP } \\
(\mathrm{mm})\end{array}$} & \multicolumn{2}{|c|}{$\begin{array}{c}\mathrm{NL} \\
\text { (número) }\end{array}$} \\
\hline Genótipo & valor & Genótipo & valor & Genótipo & valor & Genótipo & valor & Genótipo & valor & Genótipo & valor & Genótipo & valor & Genótipo & valor & Genótipo | & valor & Genótipo & valor \\
\hline 10 & $88,75 a$ & 8 & $102,00 \mathrm{a}$ & 7 & $161,25 a$ & $7 \times 1$ & $5,30 \mathrm{a}$ & 8 & $30,29 a$ & $5 \times 3$ & $208,20 a$ & 7 & $18,79 a$ & $5 \times 4$ & $8,49 a$ & $10 \times 4$ & $6,17 a$ & 2 & $3,87 a$ \\
\hline 7 & $86,75 a$ & $7 \times 2$ & $101,75 a$ & 9 & $159,25 a$ & 8 & $4,97 a$ & 9 & $28,97 a$ & $7 \times 2$ & $205,13 a$ & $7 \times 4$ & $17,99 a$ & 8 & $8,33 a$ & $10 \times 3$ & $6,12 a$ & $10 \times 4$ & $3,82 a$ \\
\hline 8 & $83,50 \mathrm{a}$ & 7 & $100,50 \mathrm{a}$ & $7 \times 2$ & $159,00 \mathrm{a}$ & 7 & $4,95 a$ & 10 & $28,85 a$ & $5 \times 4$ & $200,62 a$ & $10 \times 1$ & $\begin{array}{l}17,97 a \\
17\end{array}$ & $8 \times 2$ & $8,19 a$ & 7 & $6,07 a$ & 1 & $\begin{array}{l}3,77 a \\
3,0\end{array}$ \\
\hline $7 \times 2$ & $82,50 \mathrm{a}$ & $7 \times 4$ & $100,00 a$ & $7 \times 1$ & $158,75 a$ & $7 \times 2$ & $4,92 a$ & $7 \times 1$ & $27,05 a$ & $7 \times 4$ & $196,45 a$ & $7 \times 1$ & $17,68 a$ & $9 \times 4$ & $8,09 a$ & 10 & $6,02 a$ & $5 \times 2$ & $3,75 a$ \\
\hline 5 & $80,00 \mathrm{~b}$ & $6 \times 4$ & $99,75 a$ & 1 & $158,50 \mathrm{a}$ & 9 & $4,88 a$ & $10 \times 2$ & $26,60 \mathrm{a}$ & $7 \times 1$ & $196,26 a$ & $7 \times 2$ & $17,65 a$ & $6 \times 2$ & $8,08 a$ & $10 \times 2$ & $5,95 a$ & $10 \times 1$ & $3,75 a$ \\
\hline $8 \times 2$ & $78,75 b$ & $7 \times 3$ & $99,75 a$ & 3 & $158,25 a$ & $5 \times 3$ & $4,77 a$ & $8 \times 1$ & $26,59 a$ & 7 & $194,63 a$ & $10 \times 3$ & $17,47 a$ & 4 & $8,04 a$ & 5 & $5,94 a$ & $10 \times 3$ & $3,72 a$ \\
\hline $7 \times 1$ & $78,50 \mathrm{~b}$ & 9 & $99,75 a$ & 2 & $158,00 \mathrm{a}$ & $8 \times 1$ & $4,70 a$ & $9 \times 1$ & $26,25 a$ & $5 \times 2$ & $194,25 a$ & $5 \times 3$ & $17,35 a$ & 2 & $8,03 a$ & $5 \times 4$ & $5,68 \mathrm{~b}$ & $9 \times 2$ & $3,72 a$ \\
\hline 2 & $78,00 \mathrm{~b}$ & $8 \times 1$ & $99,50 \mathrm{a}$ & $9 \times 2$ & $157,75 a$ & $7 \times 4$ & $4,63 a$ & $5 \times 1$ & $25,58 a$ & $10 \times 4$ & $193,90 a$ & $10 \times 2$ & $\begin{array}{l}17,32 a \\
17,3\end{array}$ & $6 \times 4$ & $8,01 a$ & $\begin{array}{l}5 \times 2 \\
5 \times 2\end{array}$ & $5,61 \mathrm{~b}$ & $9 \times 1$ & $\begin{array}{l}3,72 a \\
3,12 a\end{array}$ \\
\hline $7 \times 4$ & $76,75 b$ & $10 \times 4$ & $99,25 a$ & $8 \times 3$ & $157,50 a$ & $8 \times 2$ & $4,63 a$ & $7 \times 3$ & $25,49 a$ & 3 & $188,48 \mathrm{~b}$ & $9 \times 3$ & $17,22 a$ & 5 & $8,01 a$ & $7 \times 2$ & $5,60 \mathrm{~b}$ & $5 \times 4$ & $3,70 a$ \\
\hline 9 & $75,75 b$ & $7 \times 1$ & $99,25 a$ & $7 \times 3$ & $157,50 \mathrm{a}$ & 5 & $4,57 a$ & 7 & $25,45 a$ & $8 \times 2$ & $185,84 \mathrm{~b}$ & $9 \times 1$ & $16,38 \mathrm{~b}$ & $10 \times 4$ & $7,93 a$ & $7 \times 1$ & $5,60 \mathrm{~b}$ & $8 \times 1$ & $3,67 a$ \\
\hline $10 \times 2$ & $75,75 b$ & 2 & $99,25 a$ & $9 \times 1$ & $157,50 \mathrm{a}$ & $9 \times 1$ & $4,55 a$ & 6 & $25,29 a$ & 2 & $185,12 \mathrm{~b}$ & $7 \times 3$ & $16,23 \mathrm{~b}$ & $7 \times 4$ & $7,89 a$ & $7 \times 4$ & $5,56 \mathrm{~b}$ & 9 & $3,67 a$ \\
\hline $10 \times 3$ & $74,75 b$ & $9 \times 1$ & $99,00 \mathrm{a}$ & $8 \times 1$ & $157,25 a$ & $10 \times 2$ & $4,54 a$ & $8 \times 2$ & $24,87 a$ & 5 & $184,13 \mathrm{~b}$ & 10 & $15,90 \mathrm{~b}$ & $8 \times 4$ & $7,88 a$ & 9 & $5,54 \mathrm{~b}$ & 4 & $3,65 \mathrm{a}$ \\
\hline $5 \times 3$ & $74,25 b$ & $\begin{array}{c}5 \times 1 \\
6\end{array}$ & $\begin{array}{l}99,00 \mathrm{a} \\
9\end{array}$ & $\begin{array}{l}5 \times 1 \\
5 \times 1 \\
5\end{array}$ & $\begin{array}{l}157,25 \mathrm{a} \\
\text { a }\end{array}$ & $5 \times 1$ & $4,54 a$ & $\begin{array}{c}0 \times 2 \\
5\end{array}$ & $24,85 a$ & $9 \times 4$ & $183,99 \mathrm{~b}$ & $9 \times 4$ & $15,76 \mathrm{~b}$ & $\begin{array}{l}0 \times 4 \\
7 \times 2 \\
7 \times 2\end{array}$ & $\begin{array}{l}7,00 \mathrm{~d} \\
7,87 \mathrm{a}\end{array}$ & $5 \times 3$ & $5,53 \mathrm{~b}$ & $\begin{array}{l}4 \\
3\end{array}$ & $\begin{array}{l}3,00 \mathrm{~d} \\
3,60 \mathrm{a}\end{array}$ \\
\hline $7 \times 3$ & $73,75 b$ & $8 \times 3$ & $98,50 \mathrm{a}$ & $10 \times 1$ & $157,00 \mathrm{a}$ & $10 \times 3$ & $4,43 a$ & $6 \times 1$ & $24,65 a$ & 4 & $180,53 \mathrm{c}$ & $5 \times 1$ & $15,70 \mathrm{~b}$ & $5 \times 3$ & $7,82 a$ & $10 \times 1$ & $5,50 \mathrm{~b}$ & $10 \times 2$ & $3,57 \mathrm{a}$ \\
\hline $8 \times 1$ & $73,50 \mathrm{~b}$ & $8 \times 2$ & $98,50 \mathrm{a}$ & $9 \times 3$ & $156,75 a$ & $7 \times 3$ & $4.41 a$ & $10 \times 3$ & $24.63 a$ & $10 \times 3$ & $180,24 \mathrm{c}$ & 1 & $15,60 \mathrm{~b}$ & 7 & $7,79 a$ & $9 \times 4$ & $5,49 \mathrm{~b}$ & $9 \times 4$ & $3,55 \mathrm{a}$ \\
\hline $5 \times 1$ & $73,25 \mathrm{~b}$ & 1 & $98,50 \mathrm{a}$ & 8 & $156,75 a$ & $10 \times 1$ & $4,30 \mathrm{~b}$ & $10 \times 1$ & $24,05 b$ & $8 \times 3$ & $179,71 \mathrm{c}$ & $10 \times 4$ & $15,43 \mathrm{~b}$ & $8 \times 3$ & $7,78 a$ & $5 \times 1$ & $5,47 \mathrm{~b}$ & 10 & $3,55 \mathrm{a}$ \\
\hline $5 \times 2$ & $71,25 \mathrm{c}$ & $6 \times 2$ & $98,25 \mathrm{a}$ & $10 \times 4$ & $156,25 b$ & $8 \times 3$ & $4,29 \mathrm{~b}$ & $7 \times 2$ & $24,01 \mathrm{~b}$ & $10 \times 1$ & $178,99 \mathrm{c}$ & $9 \times 2$ & $15,12 \mathrm{c}$ & $8 \times 1$ & $7,72 \mathrm{~b}$ & $8 \times 4$ & $5,46 \mathrm{~b}$ & $8 \times 2$ & $3,52 a$ \\
\hline $\begin{array}{l}5 \times 2 \\
10 \times 1\end{array}$ & $\begin{array}{l}1,1,0 \mathrm{C} \\
71,00 \mathrm{c}\end{array}$ & $\begin{array}{l}0 \times 2 \\
5 \times 4\end{array}$ & $\begin{array}{l}90,25 \mathrm{~d} \\
98,00 \mathrm{a}\end{array}$ & $9 \times 4$ & $156,25 \mathrm{~b}$ & $\begin{array}{l}0 \times 0 \\
10\end{array}$ & $\begin{array}{l}4,290 \\
4,27 \mathrm{~b}\end{array}$ & $\begin{array}{l}7 \times 2 \\
8 \times 3\end{array}$ & $\begin{array}{r}24,010 \\
23,85 b\end{array}$ & $5 \times 1$ & $178,93 \mathrm{c}$ & $\begin{array}{l}5 \times 2 \\
5 \times 2\end{array}$ & $15,01 \mathrm{c}$ & $\begin{array}{l}0 \times 1 \\
7 \times 1\end{array}$ & $7,69 \mathrm{~b}$ & $\begin{array}{c}0 \times 4 \\
2\end{array}$ & $\begin{array}{l}5,46 \mathrm{~b} \\
5,46\end{array}$ & $\begin{array}{l}0 \times 2 \\
5 \times 1\end{array}$ & $\begin{array}{l}3,5<a \\
3,52 a\end{array}$ \\
\hline 6 & $70,75 c$ & $5 \times 1$ & $98,00 \mathrm{a}$ & $7 \times 4$ & $156,25 \mathrm{~b}$ & 1 & $4,18 \mathrm{~b}$ & 1 & $23,83 b$ & $8 \times 1$ & $178,53 \mathrm{c}$ & 3 & $14,99 \mathrm{c}$ & 6 & $7,66 \mathrm{~b}$ & $6 \times 4$ & $5,43 \mathrm{~b}$ & 8 & $3,52 a$ \\
\hline $8 \times 3$ & $70,00 \mathrm{c}$ & 5 & $98,00 \mathrm{a}$ & $10 \times 3$ & $156,25 \mathrm{~b}$ & $5 \times 2$ & $4,15 \mathrm{~b}$ & $9 \times 3$ & $23,78 \mathrm{~b}$ & $9 \times 2$ & $178,15 \mathrm{c}$ & $8 \times 2$ & $14,20 \mathrm{~d}$ & 3 & $7,65 \mathrm{~b}$ & 6 & $5,41 \mathrm{~b}$ & $5 \times 3$ & $3,47 \mathrm{~b}$ \\
\hline $9 \times 1$ & $68,50 \mathrm{c}$ & $9 \times 3$ & $97,75 a$ & $10 \times 2$ & $156,25 \mathrm{~b}$ & 6 & $4,15 \mathrm{~b}$ & $7 \times 4$ & $23,73 b$ & $8 \times 4$ & $176,00 \mathrm{c}$ & 9 & $14,19 \mathrm{~d}$ & $9 \times 2$ & $7,57 \mathrm{~b}$ & $6 \times 1$ & $5,40 \mathrm{~b}$ & $9 \times 3$ & $3,45 \mathrm{~b}$ \\
\hline $9 \times 2$ & $67,50 \mathrm{c}$ & 10 & $97,75 a$ & $8 \times 2$ & $155,75 \mathrm{~b}$ & $9 \times 3$ & $4,13 \mathrm{~b}$ & $6 \times 2$ & $23,07 \mathrm{~b}$ & 1 & $175,53 \mathrm{c}$ & 2 & $14,15 \mathrm{~d}$ & $7 \times 3$ & $7,54 \mathrm{~b}$ & 4 & $5,40 \mathrm{~b}$ & 5 & $3,45 \mathrm{~b}$ \\
\hline $10 \times 4$ & $\begin{array}{l}61,20 \mathrm{c} \\
67,25 \mathrm{c}\end{array}$ & 3 & $97,75 a$ & $\begin{array}{l}0 \times 2 \\
5 \times 4\end{array}$ & $155,25 \mathrm{~b}$ & $\begin{array}{c}9 \times 0 \\
3\end{array}$ & $4,10 \mathrm{~b}$ & $\begin{array}{l}0 \times 2 \\
5 \times 3 \\
5 \times 3\end{array}$ & $22,95 b$ & $6 \times 2$ & $\begin{array}{l}17,5,53 \mathrm{c}\end{array}$ & 5 & $14,04 d$ & $\begin{array}{l}7 \times 2 \\
5 \times 2\end{array}$ & $\begin{array}{l}7,54 \mathrm{~b} \\
7,52 \mathrm{~b}\end{array}$ & $6 \times 2$ & $\begin{array}{l}5,480 \mathrm{~b} \\
\end{array}$ & $8 \times 4$ & $\begin{array}{l}3,450 \\
3,42 b\end{array}$ \\
\hline $9 \times 3$ & $67,25 c$ & $10 \times 3$ & $97,50 \mathrm{a}$ & $5 \times 2$ & $155,00 \mathrm{~b}$ & 2 & $4,09 \mathrm{~b}$ & $6 \times 4$ & $22,79 b$ & $7 \times 3$ & $173,95 \mathrm{c}$ & $8 \times 4$ & $14,01 d$ & $6 \times 1$ & $7,51 \mathrm{~b}$ & $8 \times 2$ & $5,35 b$ & $6 \times 2$ & $3,42 \mathrm{~b}$ \\
\hline 3 & $\begin{array}{l}67,00 \mathrm{c} \\
67,0\end{array}$ & $\begin{array}{l}9 \times 2 \\
9 \times 2\end{array}$ & $97,25 a$ & $\begin{array}{l}5 \times 4 \\
6 \times 4\end{array}$ & $154,75 b$ & $5 \times 4$ & $\begin{array}{l}4,06 \mathrm{~b} \\
4\end{array}$ & $\begin{array}{l}6 \times 4 \\
6 \times 3 \\
6 \times 3\end{array}$ & $\begin{array}{l}22,790 \\
22,78 b\end{array}$ & $6 \times 4$ & $173,88 \mathrm{c}$ & $\begin{array}{l}0 \times 4 \\
6 \times 3\end{array}$ & $13,75 d$ & $\begin{array}{l}5 \times 1 \\
5 \times 1\end{array}$ & $7,51 \mathrm{~b}$ & $\begin{array}{l}0 \times 2 \\
9 \times 2\end{array}$ & $5,30 \mathrm{~b}$ & $\begin{array}{l}6 \times 4 \\
6 \times 4\end{array}$ & $\begin{array}{l}3,4<0 \\
3,40 \mathrm{~b}\end{array}$ \\
\hline $9 \times 4$ & $67,00 \mathrm{c}$ & $9 \times 4$ & $97,00 \mathrm{a}$ & 6 & $154,75 \mathrm{~b}$ & $6 \times 2$ & $4,02 \mathrm{~b}$ & $8 \times 4$ & $22,59 \mathrm{~b}$ & $9 \times 3$ & $173,66 \mathrm{c}$ & $8 \times 1$ & $13,55 \mathrm{~d}$ & 1 & $7,51 \mathrm{~b}$ & 8 & $5,20 \mathrm{~b}$ & $7 \times 4$ & $3,37 \mathrm{~b}$ \\
\hline $6 \times 2$ & $65,50 \mathrm{c}$ & $8 \times 4$ & $97,00 \mathrm{a}$ & 5 & $154,75 \mathrm{~b}$ & $6 \times 1$ & $4,02 \mathrm{~b}$ & $9 \times 2$ & $22,46 b$ & $9 \times 1$ & $173,30 \mathrm{c}$ & 6 & $13,55 \mathrm{~d}$ & $6 \times 3$ & $7,50 \mathrm{~b}$ & $9 \times 1$ & $5,17 \mathrm{~b}$ & $7 \times 3$ & $3,37 \mathrm{~b}$ \\
\hline $\begin{array}{l}6 \times 2 \\
8 \times 4\end{array}$ & $\begin{array}{l}\begin{array}{l}65,30 \mathrm{c} \\
62,75 d\end{array}\end{array}$ & $\begin{array}{c}0 \times 4 \\
10 \times 2\end{array}$ & $97,00 a$ & $\begin{array}{c}5 \\
6 \times 3\end{array}$ & $\begin{array}{l}154,700 \mathrm{~b} \\
154,50 \mathrm{~s}\end{array}$ & $\begin{array}{l}6 \times 1 \\
9 \times 2\end{array}$ & $\begin{array}{l}4,0<\mathrm{b} \\
4,00 \mathrm{~b}\end{array}$ & $\begin{array}{c}9 \times 2 \\
2\end{array}$ & $\begin{array}{l}\begin{array}{l}22,4600 \\
22,03 b\end{array} \\
\text { ? }\end{array}$ & $\begin{array}{l}x 11 \\
10 \times 2\end{array}$ & $\begin{array}{l}17,3,82 \mathrm{C} \\
171,8 \mathrm{c}\end{array}$ & $8 \times 3$ & $13,53 \mathrm{~d}$ & $\begin{array}{l}6 \times 3 \\
9 \times 1\end{array}$ & $\begin{array}{l}7,500 \\
7,49 \mathrm{~b}\end{array}$ & $\begin{array}{c}9 \times 1 \\
3\end{array}$ & $5,17 \mathrm{~b}$ & $7 \times 1$ & $\begin{array}{l}3,370 \\
3,37 \mathrm{~b}\end{array}$ \\
\hline 1 & $62,50 \mathrm{~d}$ & $10 \times 1$ & $97,00 \mathrm{a}$ & $5 \times 3$ & $154,50 \mathrm{~b}$ & $8 \times 4$ & $3,97 \mathrm{~b}$ & 3 & $21,79 b$ & $6 \times 3$ & $169,74 \mathrm{c}$ & 4 & $13,53 \mathrm{~d}$ & $9 \times 3$ & $7,41 \mathrm{~b}$ & $8 \times 3$ & $5,16 \mathrm{~b}$ & $6 \times 1$ & $3,37 \mathrm{~b}$ \\
\hline $6 \times 1$ & $\begin{array}{l}62,25 d \\
62,25 d\end{array}$ & $6 \times 3$ & $96,75 a$ & $\begin{array}{l}5 \times 3 \\
6 \times 2\end{array}$ & $154,50 \mathrm{~b}$ & $\begin{array}{l}0 \times 4 \\
6 \times 4\end{array}$ & $3,93 \mathrm{~b}$ & $5 \times 2$ & $\begin{array}{l}21,190 \\
21,35 b\end{array}$ & $\begin{array}{c}0.05 \\
9\end{array}$ & $168,20 \mathrm{~d}$ & $6 \times 2$ & $12,99 \mathrm{e}$ & $\begin{array}{l}90 \\
9\end{array}$ & $\begin{array}{l}7,410 \\
7,39 \mathrm{~b}\end{array}$ & $\begin{array}{l}9 \times 3 \\
9 \times 3 \\
0\end{array}$ & $5,14 \mathrm{~b}$ & $\begin{array}{l}0 \times 1 \\
7 \times 2\end{array}$ & $\begin{array}{l}3,370 \\
3,35 b\end{array}$ \\
\hline $6 \times 4$ & $61,75 d$ & $5 \times 3$ & $96,00 \mathrm{a}$ & $6 \times 1$ & $154,00 \mathrm{~b}$ & $10 \times 4$ & $3,91 \mathrm{~b}$ & $9 \times 4$ & $20,96 \mathrm{~b}$ & 8 & $164,23 \mathrm{~d}$ & $5 \times 4$ & $12,81 \mathrm{e}$ & 10 & $7,31 \mathrm{~b}$ & $6 \times 3$ & $5,06 \mathrm{~b}$ & $8 \times 3$ & $3,25 b$ \\
\hline $5 \times 4$ & $6175 d$ & $6 \times 1$ & $96.00 \mathrm{a}$ & $8 \times 4$ & $153.75 \mathrm{~b}$ & $6 \times 3$ & $386 \mathrm{~b}$ & $5 \times 4$ & $20,35 \mathrm{~b}$ & 6 & $163.73 d$ & $6 \times 1$ & $1275 \mathrm{e}$ & $10 \times 2$ & $7.20 \mathrm{~b}$ & $8 \times 1$ & $5,00 \mathrm{~b}$ & 7 & $320 \mathrm{~b}$ \\
\hline $\begin{array}{l}5 \times 4 \\
6 \times 3\end{array}$ & $\begin{array}{l}59,50 \mathrm{~d} \\
59\end{array}$ & $\begin{array}{c}6 \times 1 \\
4\end{array}$ & $95,50 a$ & $\begin{array}{c}8 \times 4 \\
4\end{array}$ & $153,75 b$ & $\begin{array}{l}6 \times 3 \\
9 \times 4\end{array}$ & $\begin{array}{l}3,860 \\
3,85 \mathrm{~b}\end{array}$ & $\begin{array}{c}3 \times 4 \\
10 \times 4\end{array}$ & $\begin{array}{l}20,050 \\
20,14 b\end{array}$ & $6 \times 1$ & $\begin{array}{l}163, / 26 \mathrm{~d} \\
163,\end{array}$ & $\begin{array}{l}6 \times 1 \\
6 \times 4\end{array}$ & $12,74 \mathrm{e}$ & $10 \times 3$ & $\begin{array}{l}7,200 \\
7,14 \mathrm{~b}\end{array}$ & $\begin{array}{c}8 \times 1 \\
1\end{array}$ & $\begin{array}{l}4,000 \mathrm{~b} \\
4,99 \mathrm{~b}\end{array}$ & 6 & $\begin{array}{l}3,200 \\
3,15 b\end{array}$ \\
\hline 4 & $56,50 \mathrm{~d}$ & $5 \times 2$ & $95,00 \mathrm{a}$ & $\begin{array}{c}4 \\
10\end{array}$ & $153,50 \mathrm{~b}$ & 4 & $\begin{array}{l}2,890 \mathrm{~b} \\
2,89\end{array}$ & 4 & $16,10 \mathrm{~b}$ & 10 & $147.95 \mathrm{e}$ & 8 & $11,50 \mathrm{f}$ & $10 \times 1$ & $6,92 \mathrm{~b}$ & $7 \times 3$ & $4,80 \mathrm{~b}$ & $6 \times 3$ & $3,02 \mathrm{~b}$ \\
\hline
\end{tabular}

Nota : os genótipos seguidos da mesma letra não diferem entre si a 5\% de probabilidade. 
Tabela 7. Comparação entre médias: Teste de Dunnett para médias de 4 repetições de dez caracteres avaliados.

\begin{tabular}{|c|c|c|c|c|c|c|c|c|c|c|c|c|c|c|c|c|c|c|c|}
\hline \multicolumn{2}{|c|}{$\begin{array}{l}\text { APM } \\
(\mathrm{cm})\end{array}$} & \multicolumn{2}{|c|}{$\begin{array}{l}\text { NDF } \\
\text { (dias) }\end{array}$} & \multicolumn{2}{|c|}{$\begin{array}{r}\text { NDM } \\
\text { (dias) }\end{array}$} & \multicolumn{2}{|c|}{$\begin{array}{l}\text { PFP } \\
(\mathrm{Kg})\end{array}$} & \multicolumn{2}{|c|}{$\begin{array}{c}\text { NFP } \\
\text { (unidade) }\end{array}$} & \multicolumn{2}{|c|}{$\begin{array}{c}\text { PMF } \\
\text { (gramas) }\end{array}$} & \multicolumn{2}{|l|}{$\begin{array}{l}\mathrm{CF} \\
(\mathrm{cm})\end{array}$} & \multicolumn{2}{|l|}{$\begin{array}{l}\mathrm{DF} \\
(\mathrm{cm})\end{array}$} & \multicolumn{2}{|c|}{$\begin{array}{l}\mathrm{EP} \\
(\mathrm{mm})\end{array}$} & \multicolumn{2}{|c|}{$\begin{array}{c}\mathrm{NL} \\
\end{array}$} \\
\hline Genótipo & valor & Genótipo & valor & Genótipo & valor & Genótipo & valor & Genótipo & valor & \begin{tabular}{|l|} 
Genótipo \\
\end{tabular} & valor & \begin{tabular}{|l|} 
Genótipo \\
\end{tabular} & valor & Genótipo & valor & Genótipo & valor & Genótipo & valor \\
\hline 10 & 88,75 & 8 & $102,00 a$ & 7 & 161,25 & $7 \times 1$ & 5,30 & 8 & $30,29 a$ & $5 \times 3$ & 208,02 & 7 & 18,79 & $5 \times 4$ & 8,49 & $10 \times 4$ & 6,17 & 2 & 3,87 \\
\hline 7 & $86,75 a$ & $7 \times 2$ & $101,75 a$ & 9 & 159,25 & 8 & $4,97 a$ & 9 & $28,97 a$ & $7 \times 2$ & 205,13 & $7 \times 4$ & $17,99 a$ & 8 & 8,33 & $10 \times 3$ & 6,12 & $10 \times 4$ & 3,82 \\
\hline 8 & $83,50 \mathrm{a}$ & 7 & $100,50 \mathrm{a}$ & $7 \times 2$ & 159,00 & 7 & $4,95 a$ & 10 & $28,85 a$ & $5 \times 4$ & 200,62 & $10 \times 1$ & $17,97 a$ & $8 \times 2$ & 8,19 & 7 & 6,07 & 1 & $3,77 \mathrm{a}$ \\
\hline $7 \times 2$ & $82,50 \mathrm{a}$ & $7 \times 4$ & $100,00 \mathrm{a}$ & $7 \times 1$ & 158,75 & $7 \times 2$ & $4,92 a$ & $7 \times 1$ & $27,05 a$ & $7 \times 4$ & 196,45 & $7 \times 1$ & $17,68 a$ & $9 \times 4$ & 8,09 & 10 & 6,02 & $10 \times 1$ & $3,75 a$ \\
\hline 5 & $80,00 \mathrm{a}$ & 9 & $99,75 a$ & 1 & 158,50 & 9 & $4,88 a$ & $10 \times 2$ & $26,60 \mathrm{a}$ & $7 \times 1$ & 196,26 & $7 \times 2$ & $17,65 a$ & $6 \times 2$ & 8,08 & $10 \times 2$ & 5,95 & $5 \times 2$ & $3,75 a$ \\
\hline $8 \times 2$ & $78,75 a$ & $7 \times 3$ & $99,75 a$ & 3 & 158,25 & $5 \times 3$ & $4,77 a$ & $8 \times 1$ & $26,59 a$ & 7 & 194,63 & $10 \times 3$ & $17,47 a$ & 4 & 8,04 & 5 & 5,94 & $9 \times 1$ & $3,72 a$ \\
\hline $7 \times 1$ & $78,50 \mathrm{a}$ & $6 \times 4$ & $99,75 a$ & 2 & 158,00 & $8 \times 1$ & $4,70 a$ & $9 \times 1$ & $26,25 a$ & $5 \times 2$ & 194,25 & $5 \times 3$ & $17,35 a$ & 2 & 8,03 & $5 \times 4$ & 5,68 & $9 \times 2$ & $3,72 \mathrm{a}$ \\
\hline 2 & $78,00 \mathrm{a}$ & $8 \times 1$ & $99,50 \mathrm{a}$ & $9 \times 2$ & 157,75 & $8 \times 2$ & $4,63 a$ & $5 \times 1$ & $25,58 \mathrm{a}$ & $10 \times 4$ & 193,90 & $10 \times 2$ & $17,32 a$ & 5 & 8,01 & $5 \times 2$ & $5,61 a$ & $10 \times 3$ & $3,72 a$ \\
\hline $7 \times 4$ & $76,75 a$ & 2 & $99,25 a$ & $9 \times 1$ & $157,50 \mathrm{a}$ & $7 \times 4$ & $4,63 a$ & $7 \times 3$ & $25,49 a$ & 3 & 188,48 & $9 \times 3$ & $17,22 a$ & $6 \times 4$ & 8,01 & $7 \times 1$ & $5,60 a$ & $5 \times 4$ & $3,70 a$ \\
\hline $10 \times 2$ & $75,75 a$ & $7 \times 1$ & $99,25 a$ & $7 \times 3$ & $157,50 \mathrm{a}$ & 5 & $4,57 a$ & 7 & $25,45 a$ & $8 \times 2$ & 185,84 & $9 \times 1$ & $16,38 a$ & $10 \times 4$ & 7,93 & $7 \times 2$ & $5,60 \mathrm{a}$ & 9 & $3,67 a$ \\
\hline 9 & $75,75 a$ & $10 \times 4$ & $99,25 a$ & $8 \times 3$ & $157,50 \mathrm{a}$ & $9 \times 1$ & $4,55 \mathrm{a}$ & 6 & $25,29 a$ & 2 & 185,12 & $7 \times 3$ & $16,23 a$ & $7 \times 4$ & 7,89 & $7 \times 4$ & $5,56 a$ & $8 \times 1$ & $3,67 a$ \\
\hline $10 \times 3$ & $74,75 a$ & 6 & $99,00 \mathrm{a}$ & $5 \times 1$ & $157,25 a$ & $5 \times 1$ & $4,54 a$ & $8 \times 2$ & $24,87 a$ & 5 & $184,13 a$ & 10 & $15,90 a$ & $8 \times 4$ & 7,88 & 9 & $5,54 a$ & 4 & $3,65 \mathrm{a}$ \\
\hline $5 \times 3$ & $74,25 \mathrm{a}$ & $9 \times 1$ & $99,00 \mathrm{a}$ & $8 \times 1$ & $157,25 a$ & $10 \times 2$ & $\begin{array}{l}4,54 a \\
4,54 a\end{array}$ & 5 & $24,85 a$ & $9 \times 4$ & $\begin{array}{r}183,99 a \\
\end{array}$ & $9 \times 4$ & $15,76 a$ & $7 \times 2$ & 7,87 & $5 \times 3$ & $5,53 a$ & 3 & $3,60 \mathrm{a}$ \\
\hline $7 \times 3$ & $73,75 a$ & 1 & $98,50 \mathrm{a}$ & $10 \times 1$ & $157,00 \mathrm{a}$ & $10 \times 3$ & $4,43 a$ & $6 \times 1$ & $24,65 a$ & 4 & $180,53 a$ & $5 \times 1$ & $15,70 \mathrm{a}$ & $5 \times 3$ & 7,82 & $10 \times 1$ & $5,50 \mathrm{a}$ & $10 \times 2$ & $3,57 a$ \\
\hline $8 \times 1$ & $73,50 \mathrm{a}$ & $8 \times 2$ & $98,50 \mathrm{a}$ & 8 & $\begin{array}{l}156,75 a \\
\end{array}$ & $7 \times 3$ & $4,41 \mathrm{a}$ & $10 \times 3$ & $24,63 a$ & $10 \times 3$ & $180,24 a$ & 1 & $15,60 \mathrm{a}$ & 7 & 7,79 & $9 \times 4$ & $5,49 a$ & 10 & $3,55 \mathrm{a}$ \\
\hline $5 \times 1$ & $73,25 a$ & $8 \times 3$ & $98,50 \mathrm{a}$ & $9 \times 3$ & $156,75 a$ & $10 \times 1$ & $4,30 \mathrm{a}$ & $10 \times 1$ & $24,05 a$ & $8 \times 3$ & $179,71 \mathrm{a}$ & $10 \times 4$ & $15,43 a$ & $8 \times 3$ & 7,78 & $5 \times 1$ & $5,47 a$ & $9 \times 4$ & $3,55 a$ \\
\hline $5 \times 2$ & $71,25 a$ & $6 \times 2$ & $98,25 a$ & $10 \times 2$ & $156,25 a$ & $8 \times 3$ & $4,29 a$ & $7 \times 2$ & $24,01 a$ & $10 \times 1$ & $\begin{array}{l}178,99 a \\
\text { a }\end{array}$ & $9 \times 2$ & 15,12 & $8 \times 1$ & 7,72 & 2 & $5,46 a$ & 8 & $3,52 \mathrm{a}$ \\
\hline $10 \times 1$ & $71,00 \mathrm{a}$ & 5 & $98,00 \mathrm{a}$ & $10 \times 3$ & $156,25 a$ & 10 & $4,27 a$ & $8 \times 3$ & $23,85 a$ & $5 \times 1$ & $178,93 a$ & $5 \times 2$ & 15,01 & $7 \times 1$ & 7,69 & $8 \times 4$ & $5,46 a$ & $5 \times 1$ & $3,52 a$ \\
\hline 6 & $70,75 a$ & $5 \times 1$ & $98,00 a$ & $7 \times 4$ & $156,25 a$ & 1 & $4,18 a$ & 1 & $23,83 a$ & $8 \times 1$ & $178,53 a$ & 3 & 14,99 & 6 & 7, & $6 \times 4$ & $5,43 a$ & $8 \times 2$ & $3,52 a$ \\
\hline $8 \times 3$ & $70,00 \mathrm{a}$ & $5 \times 4$ & $98,00 a$ & $9 \times 4$ & $156,25 a$ & 6 & $4,15 \mathrm{a}$ & $9 \times 3$ & $23,78 a$ & $9 \times 2$ & $178,15 a$ & $8 \times 2$ & 14,20 & 3 & 7,65 & 6 & $5,41 a$ & $5 \times 3$ & $3,47 a$ \\
\hline $9 \times 1$ & $68,50 \mathrm{a}$ & 3 & $97,75 a$ & $10 \times 4$ & $156,25 a$ & $5 \times 2$ & $4,15 a$ & $7 \times 4$ & $23,73 a$ & $8 \times 4$ & $176,00 \mathrm{a}$ & 9 & 14,19 & $9 \times 2$ & $7,57 a$ & 4 & $5,40 \mathrm{a}$ & 5 & $3,45 a$ \\
\hline $9 \times 2$ & 67,50 & 10 & $97,75 a$ & $8 \times 2$ & $155,75 a$ & $9 \times 3$ & $4,13 a$ & $6 \times 2$ & $23,07 a$ & 1 & $175,53 a$ & 2 & 14,15 & $7 \times 3$ & $7,54 a$ & $6 \times 1$ & $5,40 \mathrm{a}$ & $9 \times 3$ & $3,45 a$ \\
\hline $9 \times 3$ & 67,25 & $9 \times 3$ & $97,75 a$ & $5 \times 4$ & $155,25 a$ & 3 & $4,10 a$ & $5 \times 3$ & $22,95 \mathrm{a}$ & $6 \times 2$ & $174,53 a$ & 5 & 14,04 & $5 \times 2$ & $7,52 \mathrm{a}$ & $6 \times 2$ & $5,38 a$ & $6 \times 2$ & $3,42 a$ \\
\hline $10 \times 4$ & 67,25 & $10 \times 3$ & $97,50 a$ & $5 \times 2$ & $155,00 \mathrm{a}$ & 2 & $4,09 a$ & $6 \times 4$ & $22,79 a$ & $7 \times 3$ & $173,95 a$ & $8 \times 4$ & 14,01 & 1 & $7,51 a$ & $8 \times 2$ & 5,3 & $8 \times 4$ & $3,42 a$ \\
\hline $\begin{array}{l}0 \times 4 \\
9 \times 4\end{array}$ & 67,00 & $9 \times 2$ & $97,25 a$ & $\begin{array}{c}5 \times 2 \\
5\end{array}$ & $\begin{array}{l}154,75 a \\
\end{array}$ & $5 \times 4$ & $\begin{array}{l}4,05 \mathrm{~d} \\
4,06 \mathrm{a}\end{array}$ & $\begin{array}{l}6 \times 4 \\
6 \times 3\end{array}$ & $22,78 a$ & $6 \times 4$ & $173,88 a$ & $\begin{array}{l}6 \times 4 \\
6 \times 3\end{array}$ & 13,75 & $5 \times 1$ & $7,51 a$ & $9 \times 2$ & $\begin{array}{l}5,00 \mathrm{~d} \\
5,30 \mathrm{a}\end{array}$ & $\begin{array}{l}0 \times 4 \\
6 \times 4\end{array}$ & $\begin{array}{l}0,40 \mathrm{a} \\
3,40 \mathrm{a}\end{array}$ \\
\hline 3 & 67,00 & $10 \times 1$ & $97,00 \mathrm{a}$ & 6 & $154,75 a$ & $6 \times 1$ & $4,02 \mathrm{a}$ & $8 \times 4$ & $22,59 a$ & $9 \times 3$ & $173,66 \mathrm{a}$ & 6 & 13,55 & $6 \times 1$ & $7,51 \mathrm{a}$ & 8 & $5,20 \mathrm{a}$ & $6 \times 1$ & $3,37 a$ \\
\hline $6 \times 2$ & 65,50 & $10 \times 2$ & $97,00 a$ & $6 \times 4$ & $\begin{array}{c}154,75 a \\
\end{array}$ & $6 \times 2$ & $4,02 a$ & $9 \times 2$ & $22,46 a$ & $9 \times 1$ & $173,30 \mathrm{a}$ & $8 \times 1$ & 13,55 & $6 \times 3$ & $7,50 \mathrm{a}$ & 3 & $5,17 a$ & $7 \times 1$ & $3,37 a$ \\
\hline $8 \times 4$ & 62,75 & $8 \times 4$ & $97,00 \mathrm{a}$ & $6 \times 2$ & $154,50 \mathrm{a}$ & $9 \times 2$ & $4,00 \mathrm{a}$ & 2 & $22,03 a$ & $10 \times 2$ & $171,82 a$ & 4 & 13,53 & $9 \times 1$ & $7,49 a$ & $9 \times 1$ & $5,17 a$ & $7 \times 3$ & $3,37 a$ \\
\hline 1 & 62,50 & $9 \times 4$ & $97,00 \mathrm{a}$ & $5 \times 3$ & $154,50 \mathrm{a}$ & $8 \times 4$ & $3,97 \mathrm{a}$ & 3 & $21,79 a$ & $6 \times 3$ & $\begin{array}{l}169,74 a \\
\end{array}$ & $8 \times 3$ & 13 & $9 \times 3$ & $7,41 a$ & $8 \times 3$ & 5,1 & $7 \times 4$ & $3,37 a$ \\
\hline $6 \times 1$ & 62,25 & $\begin{array}{l}5 \times 4 \\
6 \times 3\end{array}$ & $\begin{array}{l}91,70 a \\
96,75 a\end{array}$ & $6 \times 3$ & $\begin{array}{l}154,50 \mathrm{a} \\
\end{array}$ & $\begin{array}{l}6 \times 4 \\
6 \times 4\end{array}$ & $3,93 \mathrm{a}$ & $5 \times 2$ & $21,35 a$ & $\begin{array}{c}0 \times 0 \\
9\end{array}$ & $168,20 a$ & $\begin{array}{l}6 \times 2 \\
6 \times 2\end{array}$ & $\begin{array}{l}10,00 \\
12,99\end{array}$ & $\begin{array}{c}900 \\
9\end{array}$ & $\begin{array}{l}7,41 \mathrm{~d} \\
7,39 \mathrm{a}\end{array}$ & $9 \times 3$ & $\begin{array}{l}5,10 d \\
5,14 a\end{array}$ & $7 \times 2$ & $\begin{array}{l}0,35 a \\
3,35 a\end{array}$ \\
\hline $5 \times 4$ & 61,75 & $6 \times 1$ & $96,00 \mathrm{a}$ & $6 \times 1$ & $154,00 \mathrm{a}$ & $10 \times 4$ & $3,91 \mathrm{a}$ & $9 \times 4$ & $20,96 \mathrm{a}$ & 8 & $164,23 a$ & $5 \times 4$ & 12,81 & 10 & $7,31 a$ & $6 \times 3$ & $5,06 a$ & $8 \times 3$ & $3,25 \mathrm{a}$ \\
\hline $6 \times 4$ & 61,75 & $5 \times 3$ & $96,00 a$ & 4 & $\begin{array}{r}153,75 a \\
\text { a }\end{array}$ & $6 \times 3$ & $3,86 \mathrm{a}$ & $5 \times 4$ & $20,35 a$ & 6 & $163,73 a$ & $6 \times 1$ & 12,75 & $10 \times 2$ & $7,20 \mathrm{a}$ & $8 \times 1$ & $5,00 a$ & 7 & $3,20 \mathrm{a}$ \\
\hline $6 \times 3$ & 59,50 & 4 & $95,50 \mathrm{a}$ & $8 \times 4$ & $153,75 a$ & $9 \times 4$ & $3,85 \mathrm{a}$ & $10 \times 4$ & $20,14 a$ & $6 \times 1$ & $163,26 a$ & $6 \times 4$ & 12,74 & $10 \times 3$ & $7,14 a$ & 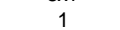 & $4,99 a$ & 6 & $3,15 a$ \\
\hline 4 & 56,50 & $5 \times 2$ & $95,00 a$ & 10 & $153,50 \mathrm{a}$ & 4 & $\begin{array}{l}2,0 \\
2,89\end{array}$ & 4 & 16,10 & 10 & 147 & 8 & 11 & $10 x$ & $6,92 a$ & $7 x$ & $4,80 \mathrm{a}$ & $6 \times 3$ & $3,02 a$ \\
\hline Magali-R & $77,25 \mathrm{a}$ & Magali-R & $\begin{array}{l}90,00 \mathrm{a} \\
97,750\end{array}$ & Magali-R & $\begin{array}{l}153,75 a \\
\end{array}$ & Magali-R & $\begin{array}{l}2,05 \\
4,10 a\end{array}$ & Magali-R & $24,76 a$ & Magali-R & $165,45 a$ & Magali-R & $\begin{array}{c}17,05 a \\
\text { a }\end{array}$ & Magali-R & $\begin{array}{l}0, y<\mathrm{a} \\
6,87 \mathrm{a}\end{array}$ & Magali-R & $\begin{array}{r}4,00 d \\
4,64 a\end{array}$ & Magali-R & $\begin{array}{l}5,0<a \\
3,29 a\end{array}$ \\
\hline
\end{tabular}

Nota : os genótipos seguidos da mesma letra não diferem entre si a 5\% de probabilidade. 
Tabela 8. Heterose em relação à média dos genitores (MG), em relação ao genitor resistente ao PVY (GRPVY), em relação ao genitor suscetível ao PVY (GSPVY) e em relação ao híbrido padrão (HP) para o caráter altura de planta na maturidade.

\begin{tabular}{|c|c|c|c|c|c|c|c|c|}
\hline \multirow[b]{2}{*}{ Híbrido } & \multicolumn{2}{|c|}{$\begin{array}{c}\text { heterose } \\
\text { MG }^{\text {a/ }}\end{array}$} & \multicolumn{2}{|c|}{$\begin{array}{l}\text { heterose } \\
\text { GRPVY }^{\text {a/ }}\end{array}$} & \multicolumn{2}{|c|}{$\begin{array}{l}\text { heterose } \\
\text { GSPVY }^{\text {a/ }}\end{array}$} & \multicolumn{2}{|c|}{$\begin{array}{c}\text { heterose } \\
\mathrm{HP}^{\mathrm{b} /}\end{array}$} \\
\hline & valor & $\%$ & valor & $\%$ & valor & $\%$ & valor & $\%$ \\
\hline $5 \times 1$ & 2,00 & 2,81 & $10,75^{*}$ & 17,20 & $-6,75^{*}$ & $-8,44$ & $-4,00$ & $-5,18$ \\
\hline $6 \times 1$ & $-4,37^{*}$ & $-6,57$ & $-0,25$ & $-0,40$ & $-8,50 *$ & $-12,01$ & $-15,00^{*}$ & $-19,42$ \\
\hline $7 \times 1$ & 3,87 & 5,19 & $16,00^{*}$ & 25,60 & $-8,25 *$ & $-9,51$ & 1,25 & 1,62 \\
\hline $8 \times 1$ & 0,50 & 0,68 & $11,00^{*}$ & 17,60 & $-10,00 *$ & $-11,98$ & $-3,75$ & $-4,85$ \\
\hline $9 \times 1$ & $-0,62$ & $-0,90$ & $6,00 *$ & 9,60 & $-7,25^{*}$ & $-9,57$ & $-8,75$ & $-11,33$ \\
\hline $10 \times 1$ & $-4,62^{*}$ & $-6,11$ & $8,50 *$ & 13,60 & $-17,75^{*}$ & $-20,00$ & $-6,25$ & $-8,09$ \\
\hline $5 \times 2$ & $-7,75^{*}$ & $-9,81$ & $-6,75^{*}$ & $-8,65$ & $-8,75^{*}$ & $-10,94$ & $-6,00$ & $-7,77$ \\
\hline $6 \times 2$ & $-8,87^{*}$ & $-11,93$ & $-12,50 *$ & $-16,03$ & $-5,25 *$ & $-7,42$ & $-11,75^{*}$ & $-15,21$ \\
\hline $7 \times 2$ & 0,12 & 0,15 & 4,50 & 5,77 & $-4,25$ & $-4,90$ & 5,25 & 6,80 \\
\hline $8 \times 2$ & $-2,00$ & $-2,48$ & 0,75 & 0,96 & $-4,75^{*}$ & $-5,69$ & 1,50 & 1,94 \\
\hline $9 \times 2$ & $-9,37 *$ & $-12,19$ & $-10,50 *$ & $-13,46$ & $-8,25 *$ & $-10,89$ & $-9,75^{*}$ & $-12,62$ \\
\hline $10 \times 2$ & $-7,62^{*}$ & $-9,14$ & $-2,25$ & $-2,88$ & $-13,00^{*}$ & $-14,65$ & $-1,50$ & $-1,94$ \\
\hline $5 \times 3$ & 0,75 & 1,02 & $7,25 *$ & 10,82 & $-5,75^{*}$ & $-7,19$ & $-3,00$ & $-3,88$ \\
\hline $6 \times 3$ & $-9,37 *$ & $-13,61$ & $-7,50^{*}$ & $-11,19$ & $-11,25 *$ & $-15,90$ & $-17,75^{*}$ & $-22,98$ \\
\hline $7 \times 3$ & $-3,12$ & $-4,06$ & $6,75^{*}$ & 10,07 & $-13,00^{*}$ & $-14,99$ & $-3,50$ & $-4,53$ \\
\hline $8 \times 3$ & $-5,25^{*}$ & $-6,98$ & 3,00 & 4,48 & $-13,50^{*}$ & $-16,17$ & $-7,25$ & $-9,38$ \\
\hline $9 \times 3$ & $-4,12^{*}$ & $-5,78$ & 0,25 & 0,37 & $-8,50^{*}$ & $-11,22$ & $-10,00^{*}$ & $-12,94$ \\
\hline $10 \times 3$ & $-3,12$ & $-4,01$ & $7,75^{*}$ & 11,57 & $-14,00^{*}$ & $-15,77$ & $-2,50$ & $-3,24$ \\
\hline $5 \times 4$ & $-6,50 *$ & $-9,52$ & $5,25 *$ & 9,29 & $-18,25^{*}$ & $-22,81$ & $-15,50 *$ & $-20,06$ \\
\hline $6 \times 4$ & $-1,87$ & $-2,95$ & $5,25 *$ & 9,29 & $-9,00^{*}$ & $-12,72$ & $-15,50^{*}$ & $-20,06$ \\
\hline $7 \times 4$ & $5,13^{*}$ & 7,15 & $20,25^{*}$ & 35,84 & $-10,00^{*}$ & $-11,53$ & $-0,50$ & $-0,65$ \\
\hline $8 \times 4$ & $-7,25^{*}$ & $-10,36$ & $6,25^{*}$ & 11,06 & $-20,75^{*}$ & $-24,85$ & $-14,50 *$ & $-18,77$ \\
\hline $9 \times 4$ & 0,87 & 1,32 & $10,50 *$ & 18,58 & $-8,75^{*}$ & $-11,55$ & $-10,25^{*}$ & $-13,27$ \\
\hline $10 \times 4$ & $-5,37^{*}$ & $-7,40$ & $10,75^{*}$ & 19,03 & $-21,50^{*}$ & $-24,22$ & $-10,00^{*}$ & $-12,94$ \\
\hline
\end{tabular}

a/ heteroses (MG, GRPVY, GSPVY) : teste t a 5\% de probabilidade

b/ heterose (HP) : teste de Dunnet a 5\% de probabilidade 


\subsubsection{Número de dias para o florescimento}

Para este caráter, é interessante que ocorra heterose negativa, pois um menor número de dias para o florescimento (NDF), de certa forma é uma medida de precocidade.

O HP Magali-R apresentou valor de 97,75 dias para a abertura da segunda flor. O híbrido que apresentou o maior valor para NDF foi o 7x2 (101,75 dias) e o menor valor foi o do híbrido 5x2 (95 dias). Embora os testes de Scott-Knott (Tabela 6) e de Dunnett (Tabela 7) não terem detectado diferenças significativas entre os tratamentos para NDF, as análises de variância (Tabelas 4 e 5) indicaram significância a 5\% pelo teste F.

$\mathrm{O}$ teste $\mathrm{t}$ revelou baixos valores de heterose negativa em relação à MG (máximo de -3,68\%), em relação aos GRPVY (máximo de -4,28\%) e em relação aos GSPVY (máximo de -4,90\%), com significância a 5\% (Tabela 9).

Ming et al. (1986) trabalhando com cruzamentos envolvendo pimentões e pimentas, também obtiveram valores baixos e significativos de heterose $(-5,69 \%)$.

Nenhum híbrido apresentou heterose significativa em relação ao HP Magali-R (Tabela 9).

\subsubsection{Número de dias para a maturidade}

Assim como para o número de dias para o florescimento, o caráter número de dias para a maturidade (NDM) é também uma medida de precocidade, e como tal, interessa que assuma os menores valores possíveis.

Nenhum dos híbridos apresentou um valor menor para NDM que o HP Magali-R, que obteve 153,75 dias para este caráter, indicando ser este um 
Tabela 9. Heterose em relação à média dos genitores (MG), em relação ao genitor resistente ao PVY (GRPVY), em relação ao genitor suscetível ao PVY (GSPVY) e em relação ao híbrido padrão (HP) para o caráter número de dias para o florescimento.

\begin{tabular}{|c|c|c|c|c|c|c|c|c|}
\hline \multirow[b]{2}{*}{ Híbrido } & \multicolumn{2}{|c|}{$\begin{array}{c}\text { heterose } \\
\text { MG }^{a /}\end{array}$} & \multicolumn{2}{|c|}{$\begin{array}{l}\text { heterose } \\
\text { GRPVY }^{\text {a/ }}\end{array}$} & \multicolumn{2}{|c|}{$\begin{array}{l}\text { heterose } \\
\text { GSPVY }^{\text {al }}\end{array}$} & \multicolumn{2}{|c|}{$\begin{array}{c}\text { heterose } \\
\mathrm{HP}^{\mathrm{b} /}\end{array}$} \\
\hline & valor & $\%$ & valor & $\%$ & valor & $\%$ & valor & $\%$ \\
\hline $5 \times 1$ & $-0,25$ & $-0,25$ & $-0,50$ & $-0,51$ & 0,00 & 0,00 & 0,25 & 0,26 \\
\hline $6 \times 1$ & $-2,75^{*}$ & $-2,79$ & $-2,50 *$ & $-2,54$ & $-3,00 *$ & $-3,03$ & $-1,75$ & $-1,79$ \\
\hline $7 \times 1$ & $-0,25$ & $-0,25$ & 0,75 & 0,76 & $-1,25$ & $-1,24$ & 1,50 & 1,53 \\
\hline $8 \times 1$ & $-0,75$ & $-0,75$ & 1,00 & 1,02 & $-2,50 *$ & $-2,45$ & 1,75 & 1,79 \\
\hline $9 \times 1$ & $-0,13$ & $-0,13$ & 0,50 & 0,51 & $-0,75$ & $-0,75$ & 1,25 & 1,28 \\
\hline $10 \times 1$ & $-1,13$ & $-1,15$ & $-1,50$ & $-1,52$ & $-0,75$ & $-0,77$ & $-0,75$ & $-0,77$ \\
\hline $5 \times 2$ & $-3,63^{*}$ & $-3,68$ & $-4,25^{*}$ & $-4,28$ & $-3,00 *$ & $-3,06$ & $-2,75$ & $-2,81$ \\
\hline $6 \times 2$ & $-0,88$ & $-0,88$ & $-1,00$ & $-1,01$ & $-0,75$ & $-0,76$ & 0,50 & 0,51 \\
\hline $7 \times 2$ & 1,88 & 1,88 & $2,50^{*}$ & 2,52 & 1,25 & 1,24 & 4,00 & 4,09 \\
\hline $8 \times 2$ & $-2,13^{*}$ & $-2,11$ & $-0,75$ & $-0,76$ & $-3,50 *$ & $-3,43$ & 0,75 & 0,77 \\
\hline $9 \times 2$ & $-2,25^{*}$ & $-2,26$ & $-2,00$ & $-2,02$ & $-2,50 *$ & $-2,51$ & $-0,50$ & $-0,51$ \\
\hline $10 \times 2$ & $-1,50$ & $-1,52$ & $-2,25$ & $-2,27$ & $-0,75$ & $-0,77$ & $-0,75$ & $-0,77$ \\
\hline $5 \times 3$ & $-1,88$ & $-1,92$ & $-1,75$ & $-1,79$ & $-2,00$ & $-2,04$ & $-1,75$ & $-1,79$ \\
\hline $6 \times 3$ & $-1,63$ & $-1,65$ & $-1,00$ & $-1,02$ & $-2,25$ & $-2,27$ & $-1,00$ & $-1,02$ \\
\hline $7 \times 3$ & 0,63 & 0,63 & 2,00 & 2,05 & $-0,75$ & $-0,75$ & 2,00 & 2,05 \\
\hline $8 \times 3$ & $-1,38$ & $-1,38$ & 0,75 & 0,77 & $-3,50 *$ & $-3,43$ & 0,75 & 0,77 \\
\hline $9 \times 3$ & $-1,00$ & $-1,01$ & 0,00 & 0,00 & $-2,00$ & $-2,01$ & 0,00 & 0,00 \\
\hline $10 \times 3$ & $-0,25$ & $-0,26$ & $-0,25$ & $-0,26$ & $-0,25$ & $-0,26$ & $-0,25$ & $-0,26$ \\
\hline $5 \times 4$ & 1,25 & 1,29 & $2,50 *$ & 2,62 & 0,00 & 0,00 & 0,25 & 0,26 \\
\hline $6 \times 4$ & $2,50 *$ & 2,57 & $4,25 *$ & 4,45 & 0,75 & 0,76 & 2,00 & 2,05 \\
\hline $7 \times 4$ & 2,00 & 2,04 & $4,50 *$ & 4,71 & $-0,50$ & $-0,50$ & 2,25 & 2,30 \\
\hline $8 \times 4$ & $-1,75$ & $-1,77$ & 1,50 & 1,57 & $-5,00 *$ & $-4,90$ & $-0,75$ & $-0,77$ \\
\hline $9 \times 4$ & $-0,63$ & $-0,64$ & 1,50 & 1,57 & $-2,75^{*}$ & $-2,76$ & $-0,75$ & $-0,77$ \\
\hline $10 \times 4$ & $2,63^{*}$ & 2,72 & $3,75^{*}$ & 3,93 & 1,50 & 1,54 & 1,50 & 1,53 \\
\hline
\end{tabular}

a/ heteroses (MG, GRPVY, GSPVY) : teste t a 5\% de probabilidade

$\mathrm{b} /$ heterose (HP) : teste de Dunnet a 5\% de probabilidade 
híbrido bastante precoce. Juntamente com o HP, o híbrido $8 \times 4$ apresentou o menor valor para o caráter, com idênticos 153,75 dias para início de maturação de seus frutos. O maior valor obtido para NDM foi no híbrido 7x2 com 159,00 dias para a maturidade (Tabela 7).

Foram observados valores de heterose negativa baixos, mas significativos a $5 \%$ pelo teste $\mathrm{t}$ : em relação à $\mathrm{MG}$ (máximo de $-1,68 \%$ ), em relação aos GRPVY (máximo de -2,84\%) e em relação aos GSPVY (máximo de $-3,10 \%)$, Tabela 10. No entanto, em pimenta, alguns autores como Doshi \& Shukla (2000a), Kumar \& Lal (2001) e Mishra et al. (1988) encontraram valores maiores de heterobeltiose $(-32,03 \%,-14,65 \%$ e $-27,62 \%$, respectivamente) para o NDM.

\subsubsection{Produção de frutos por planta}

Os valores para produção de frutos por planta (PFP) variaram de 3,85 (9x4) a 5,30 Kg (7x1) entre os híbridos (Tabela 6). Vários destes híbridos apresentaram valores de PFP superiores ao do HP, mas apenas o híbrido 7x1 obteve um valor de PFP significativamente diferente de Magali-R, segundo o teste de Dunnett a 5\% (Tabela 7), ou seja, 5,30Kg contra 4,10Kg, respectivamente. Esta diferença de produção resultou em uma heterose significativa de 29,27\% do híbrido 7x1 em relação ao HP Magali-R (Tabela $11)$.

Heteroses positivas e significativas em relação à $\mathrm{MG}$ foram observadas para os híbridos 7x1 (16,10\%) e 7x4 (18,11\%), Tabela 11. Estes resultados estão de acordo com Depestre \& Espinosa (1988) que verificaram heteroses de 16,6 a 29,5\% em pimentão para PFP. 
Tabela 10. Heterose em relação à média dos genitores (MG), em relação ao genitor resistente ao PVY (GRPVY), em relação ao genitor suscetível ao PVY (GSPVY) e em relação ao híbrido padrão (HP) para o caráter número de dias para a maturidade.

\begin{tabular}{|c|c|c|c|c|c|c|c|c|}
\hline \multirow[b]{2}{*}{ Híbrido } & \multicolumn{2}{|c|}{$\begin{array}{c}\text { heterose } \\
\text { MG }^{\mathrm{a}}\end{array}$} & \multicolumn{2}{|c|}{$\begin{array}{l}\text { heterose } \\
\text { GRPVY }^{\text {a/ }}\end{array}$} & \multicolumn{2}{|c|}{$\begin{array}{l}\text { heterose } \\
\text { GSPVY }^{\text {a/ }}\end{array}$} & \multicolumn{2}{|c|}{$\begin{array}{c}\text { heterose } \\
\qquad \mathrm{HP}^{\mathrm{b} /}\end{array}$} \\
\hline & valor & $\%$ & valor & $\%$ & valor & $\%$ & valor & $\%$ \\
\hline $5 \times 1$ & 0,63 & 0,40 & $-1,25$ & $-0,79$ & $2,50 *$ & 1,62 & 3,50 & 2,28 \\
\hline $6 \times 1$ & $-2,63^{*}$ & $-1,68$ & $-4,50^{*}$ & $-2,84$ & $-0,75$ & $-0,49$ & 0,25 & 0,16 \\
\hline $7 \times 1$ & $-1,13$ & $-0,70$ & 0,25 & 0,16 & $-2,50 *$ & $-1,55$ & $5,00 *$ & 3,25 \\
\hline $8 \times 1$ & $-0,38$ & $-0,24$ & $-1,25$ & $-0,79$ & 0,50 & 0,32 & 3,50 & 2,28 \\
\hline $9 \times 1$ & $-1,38$ & $-0,87$ & $-1,00$ & $-0,63$ & $-1,75$ & $-1,10$ & 3,75 & 2,44 \\
\hline $10 \times 1$ & 1,00 & 0,64 & $-1,50$ & $-0,95$ & $3,50 *$ & 2,28 & 3,25 & 2,11 \\
\hline $5 \times 2$ & $-1,38$ & $-0,88$ & $-3,00^{*}$ & $-1,90$ & 0,25 & 0,16 & 1,25 & 0,81 \\
\hline $6 \times 2$ & $-1,88^{*}$ & $-1,20$ & $-3,50 *$ & $-2,22$ & $-0,25$ & $-0,16$ & 0,75 & 0,49 \\
\hline $7 \times 2$ & $-0,63$ & $-0,39$ & 1,00 & 0,63 & $-2,25^{*}$ & $-1,40$ & $5,25^{*}$ & 3,42 \\
\hline $8 \times 2$ & $-1,63^{*}$ & $-1,03$ & $-2,25^{*}$ & $-1,42$ & $-1,00$ & $-0,64$ & 2,00 & 1,30 \\
\hline $9 \times 2$ & $-0,88$ & $-0,55$ & $-0,25$ & $-0,16$ & $-1,50$ & $-0,94$ & $4,00 *$ & 2,60 \\
\hline $10 \times 2$ & 0,50 & 0,32 & $-1,75$ & $-1,11$ & $2,75^{*}$ & 1,79 & 2,50 & 1,63 \\
\hline $5 \times 3$ & $-2,00 *$ & $-1,28$ & $-3,75^{*}$ & $-2,37$ & $-0,25$ & $-0,16$ & 0,75 & 0,49 \\
\hline $6 \times 3$ & $-2,00 *$ & $-1,28$ & $-3,75^{*}$ & $-2,37$ & $-0,25$ & $-0,16$ & 0,75 & 0,49 \\
\hline $7 \times 3$ & $-2,25^{*}$ & $-1,41$ & $-0,75$ & $-0,47$ & $-3,75^{*}$ & $-2,33$ & 3,75 & 2,44 \\
\hline $8 \times 3$ & 0,00 & 0,00 & $-0,75$ & $-0,47$ & 0,75 & 0,48 & 3,75 & 2,44 \\
\hline $9 \times 3$ & $-2,00 *$ & $-1,26$ & $-1,50$ & $-0,95$ & $-2,50 *$ & $-1,57$ & 3,00 & 1,95 \\
\hline $10 \times 3$ & 0,38 & 0,24 & $-2,00^{*}$ & $-1,26$ & $2,75^{*}$ & 1,79 & 2,50 & 1,63 \\
\hline $5 \times 4$ & 1,00 & 0,65 & 1,50 & 0,98 & 0,50 & 0,32 & 1,50 & 0,98 \\
\hline $6 \times 4$ & 0,50 & 0,32 & 1,00 & 0,65 & 0,00 & 0,00 & 1,00 & 0,65 \\
\hline $7 \times 4$ & $-1,25$ & $-0,79$ & $2,50 *$ & 1,63 & $-5,00 *$ & $-3,10$ & 2,50 & 1,63 \\
\hline $8 \times 4$ & $-1,50$ & $-0,97$ & 0,00 & 0,00 & $-3,00^{*}$ & $-1,91$ & 0,00 & 0,00 \\
\hline $9 \times 4$ & $-0,25$ & $-0,16$ & $2,50 *$ & 1,63 & $-3,00^{*}$ & $-1,88$ & 2,50 & 1,63 \\
\hline $10 \times 4$ & $2,63^{*}$ & 1,71 & $2,50 *$ & 1,63 & $2,75^{*}$ & 1,79 & 2,50 & 1,63 \\
\hline
\end{tabular}

a/ heteroses (MG, GRPVY, GSPVY) : teste t a 5\% de probabilidade

b/ heterose (HP) : teste de Dunnet a 5\% de probabilidade 
Tabela 11. Heterose em relação à média dos genitores (MG), em relação ao genitor resistente ao PVY (GRPVY), em relação ao genitor suscetível ao PVY (GSPVY) e em relação ao híbrido padrão (HP) para o caráter produção de frutos por planta.

\begin{tabular}{|c|c|c|c|c|c|c|c|c|}
\hline \multirow[b]{2}{*}{ Híbrido } & \multicolumn{2}{|c|}{$\begin{array}{c}\text { heterose } \\
\text { MG }^{\text {a/ }}\end{array}$} & \multicolumn{2}{|c|}{$\begin{array}{l}\text { heterose } \\
\text { GRPVY }^{\text {al }}\end{array}$} & \multicolumn{2}{|c|}{$\begin{array}{l}\text { heterose } \\
\text { GSPVY }^{\text {al }}\end{array}$} & \multicolumn{2}{|c|}{$\begin{array}{c}\text { heterose } \\
\mathrm{HP}^{\mathrm{b} /}\end{array}$} \\
\hline & valor & $\%$ & valor & $\%$ & valor & $\%$ & valor & $\%$ \\
\hline $5 \times 1$ & 0,17 & 3,77 & 0,36 & 8,61 & $-0,03$ & $-0,66$ & 0,44 & 10,73 \\
\hline $6 \times 1$ & $-0,15$ & $-3,48$ & $-0,16$ & $-3,83$ & $-0,13$ & $-3,13$ & $-0,08$ & $-1,95$ \\
\hline $7 \times 1$ & $0,74^{*}$ & 16,10 & $1,12^{*}$ & 26,79 & 0,35 & 7,07 & $1,20^{*}$ & 29,27 \\
\hline $8 \times 1$ & 0,13 & 2,73 & 0,52 & 12,44 & $-0,27$ & $-5,43$ & 0,60 & 14,63 \\
\hline $9 \times 1$ & 0,02 & 0,44 & 0,37 & 8,85 & $-0,33$ & $-6,76$ & 0,45 & 10,98 \\
\hline $10 \times 1$ & 0,08 & 1,78 & 0,12 & 2,87 & 0,03 & 0,70 & 0,20 & 4,88 \\
\hline $5 \times 2$ & $-0,18$ & $-4,16$ & 0,06 & 1,47 & $-0,42$ & $-9,19$ & 0,05 & 1,22 \\
\hline $6 \times 2$ & $-0,10$ & $-2,43$ & $-0,07$ & $-1,71$ & $-0,13$ & $-3,13$ & $-0,08$ & $-1,95$ \\
\hline $7 \times 2$ & 4,00 & 8,85 & $0,83^{*}$ & 20,29 & $-0,03$ & $-0,61$ & 0,82 & 20,00 \\
\hline $8 \times 2$ & 1,00 & 2,21 & $0,54^{*}$ & 13,20 & $-0,34$ & $-6,84$ & 0,53 & 12,93 \\
\hline $9 \times 2$ & $-0,49 *$ & $-10,81$ & $-0,09$ & $-2,20$ & $-0,88^{*}$ & $-18,03$ & $-0,10$ & $-2,44$ \\
\hline $10 \times 2$ & 0,36 & 8,61 & 0,45 & 11,00 & 0,27 & 6,32 & 0,44 & 10,73 \\
\hline $5 \times 3$ & 0,44 & 10,04 & $0,67 *$ & 16,34 & 0,20 & 4,38 & 0,67 & 16,34 \\
\hline $6 \times 3$ & $-0,27$ & $-6,42$ & $-0,24$ & $-5,85$ & $-0,29$ & $-6,99$ & $-0,24$ & $-5,85$ \\
\hline $7 \times 3$ & $-0,12$ & $-2,54$ & 0,31 & 7,56 & $-0,54 *$ & $-10,91$ & 0,31 & 7,56 \\
\hline $8 \times 3$ & $-0,25$ & $-5,40$ & 0,19 & 4,63 & $-0,68 *$ & $-13,68$ & 0,19 & 4,63 \\
\hline $9 \times 3$ & $-0,36$ & $-8,02$ & 0,03 & 0,73 & $-0,75^{*}$ & $-15,37$ & 0,03 & 0,73 \\
\hline $10 \times 3$ & 0,25 & 5,85 & 0,33 & 8,05 & 0,16 & 3,75 & 0,33 & 8,05 \\
\hline $5 \times 4$ & 0,33 & 8,85 & $1,17^{*}$ & 40,48 & $-0,51$ & $-11,16$ & $-0,04$ & $-0,98$ \\
\hline $6 \times 4$ & 0,41 & 11,65 & $1,04^{*}$ & 35,99 & $-0,22$ & $-5,30$ & $-0,17$ & $-4,15$ \\
\hline $7 \times 4$ & $0,71^{*}$ & 18,11 & $1,74^{*}$ & 60,21 & $-0,32$ & $-6,47$ & 0,53 & 12,93 \\
\hline $8 \times 4$ & 0,04 & 1,02 & $1,08^{*}$ & 37,37 & $-1,00 *$ & $-20,12$ & $-0,13$ & $-3,17$ \\
\hline $9 \times 4$ & $-0,35$ & $-0,90$ & $0,96 *$ & 33,22 & $-1,03 *$ & $-21,11$ & $-0,25$ & $-6,10$ \\
\hline $10 \times 4$ & 0,33 & 9,22 & $1,02 *$ & 35,29 & $-0,36$ & $-8,43$ & $-0,19$ & $-4,63$ \\
\hline
\end{tabular}

a/ heteroses (MG, GRPVY, GSPVY) : teste t a 5\% de probabilidade

b/ heterose (HP) : teste de Dunnet a 5\% de probabilidade 
Também foram observadas heteroses positivas significativas em relação aos GRPVY, variando de 13,20\% (híbrido 8x2) a 60,21\% (híbrido 7x4), Tabela 11.

Valores negativos e significativos de heterose em relação aos GSPVY foram encontrados para PFP, variando de $-10,91$ a $-21,11 \%$. Neste ponto, cabe fazer a seguinte observação : embora alguns genitores $(7,8$ e 9 por exemplo) tenham apresentado valores de PFP superiores aos dos próprios híbridos nos quais eles estão envolvidos, os mesmos encontrariam limitação quanto à resistência ao PVY para serem utilizados diretamente como cultivares comerciais (Tabela 11).

\subsubsection{Número de frutos por planta}

Os valores para número de frutos por planta (NFP) variaram de 20,14 (10x4) a 27,05 (7x1) entre os híbridos (Tabela 6).

Pelo teste de Dunnett (Tabela 7), nenhum dos híbridos apresentou valores significativamente diferentes ao do HP Magali-R, que obteve o valor de 24,76 para este caráter.

Heterose de $14,22 \%$ em relação à $M G$ foi detectada no híbrido $7 \times 4$ pelo teste t (Tabela 12). Depestre \& Espinosa (1988) também encontraram valores baixos de heterose (11 a 28\%) para NFP em pimentão.

De especial interesse são os valores positivos e significativos de heterose entre 13,51 (híbrido 7x1) e 47,39\% (híbrido 7x4) em relação aos GRPVY (Tabela 12).

Valores significativos de heterose negativa em relação aos GSPVY são observados para muitos híbridos, indicando serem muitos dos genitores (5, 8, 9 e 10, por exemplo) superiores aos híbridos dos quais fazem parte (Tabela 
12); porém, a utilização de tais genitores como cultivares estaria comprometida pelo fato dos mesmos serem suscetíveis ao PVY.

\subsubsection{Peso médio de fruto}

O peso médio de fruto (PMF) é um caráter importante para a determinação da produção em pimentão, pois ele fornece uma idéia do tamanho dos frutos, embora o caráter espessura de pericarpo também esteja envolvido na determinação do PMF. Uma vez que a maior parte dos produtores vende a sua produção em caixa "K", estes produtores costumam medí-la utilizando a relação número de caixas "K" produzidas por mil plantas. Certamente, quanto maior o tamanho dos frutos, menor será o número de frutos necessários para se preencher uma caixa "K" e, portanto, a produção será maior.

Cinco diferentes grupos foram identificados pelo teste de ScottKnott, cujos valores para PMF variaram de 163,26 (6x1) a 208,20 gramas (5x3), entre os híbridos (Tabela 6).

O teste de Dunnett identificou vários híbridos com valores de PMF superiores ao do HP Magali-R, cujo valor alcançado para este caráter foi de 165,45 gramas (Tabela 7). Em função disso, vários híbridos apresentaram heterose significativa em relação a Magali-R, sendo que os valores variaram de 12,32\% (híbrido 8x2) a 25,73\% (híbrido 5x3), Tabela 13.

Valores significativos de heterose de 4,73 (híbrido 7x4) a 18,06\% (híbrido 10x4) em relação à MG foram observados (Tabela 13). Heterose para o caráter peso médio de fruto em pimentão também foram encontrados por outros autores : Ming et al. (1986), Miranda (1987) e Panayotov et al. (2000). 
Tabela 12. Heterose em relação à média dos genitores (MG), em relação ao genitor resistente ao PVY (GRPVY), em relação ao genitor suscetível ao PVY (GSPVY) e em relação ao híbrido padrão (HP) para o caráter número de frutos produzidos por planta.

\begin{tabular}{|c|c|c|c|c|c|c|c|c|}
\hline \multirow[b]{2}{*}{ Híbridos } & \multicolumn{2}{|c|}{$\begin{array}{c}\text { heterose } \\
\text { MG }^{\mathrm{a}}\end{array}$} & \multicolumn{2}{|c|}{$\begin{array}{l}\text { heterose } \\
\text { GRPVY }^{\text {a/ }}\end{array}$} & \multicolumn{2}{|c|}{$\begin{array}{l}\text { heterose } \\
\text { GSPVY }^{\text {al }}\end{array}$} & \multicolumn{2}{|c|}{$\begin{array}{c}\text { heterose } \\
\mathrm{HP}^{\mathrm{b} /}\end{array}$} \\
\hline & valor & $\%$ & valor & $\%$ & valor & $\%$ & valor & $\%$ \\
\hline $5 \times 1$ & 1,24 & 5,09 & 1,75 & 7,34 & 0,73 & 2,94 & 0,82 & 3,31 \\
\hline $6 \times 1$ & 0,09 & 0,37 & 0,82 & 3,44 & $-0,64$ & $-2,53$ & $-0,11$ & $-0,44$ \\
\hline $7 \times 1$ & 2,41 & 9,78 & $3,22 *$ & 13,51 & 1,60 & 6,29 & 2,29 & 9,25 \\
\hline $8 \times 1$ & $-0,47$ & $-1,74$ & 2,76 & 11,58 & $-3,70^{*}$ & $-12,22$ & 1,83 & 7,39 \\
\hline $9 \times 1$ & $-0,15$ & $-0,57$ & 2,42 & 10,16 & $-2,72$ & $-9,39$ & 1,49 & 6,02 \\
\hline $10 \times 1$ & $-2,29$ & $-8,69$ & 0,22 & 0,92 & $-4,80 *$ & $-16,64$ & $-0,71$ & $-2,87$ \\
\hline $5 \times 2$ & $-2,09$ & $-8,92$ & $-0,68$ & $-3,09$ & $-3,50 *$ & $-14,09$ & $-3,41$ & $-13,77$ \\
\hline $6 \times 2$ & $-0,59$ & $-2,49$ & 1,04 & 4,72 & $-2,22$ & $-8,78$ & $-1,69$ & $-6,82$ \\
\hline $7 \times 2$ & 0,27 & 1,14 & 1,98 & 8,99 & $-1,44$ & $-5,66$ & $-0,75$ & $-3,03$ \\
\hline $8 \times 2$ & $-1,29$ & $-4,93$ & 2,84 & 12,89 & $-5,42 *$ & $-17,89$ & 0,11 & 0,44 \\
\hline $9 \times 2$ & $-3,04 *$ & $-11,92$ & 0,43 & 1,95 & $-6,51^{*}$ & $-22,47$ & $-2,30$ & $-9,29$ \\
\hline $10 \times 2$ & 1,16 & 4,56 & $4,57 *$ & 20,74 & $-2,25$ & $-7,80$ & 1,84 & 7,43 \\
\hline $5 \times 3$ & $-0,37$ & $-1,59$ & 1,16 & 5,32 & $-1,90$ & $-7,65$ & $-1,81$ & $-7,31$ \\
\hline $6 \times 3$ & $-0,76$ & $-3,23$ & 0,99 & 4,54 & $-2,51$ & $-9,93$ & $-1,98$ & $-8,00$ \\
\hline $7 \times 3$ & 1,87 & 7,92 & $3,70^{*}$ & 16,98 & 0,04 & 0,16 & 0,73 & 2,95 \\
\hline $8 \times 3$ & $-2,19$ & $-8,41$ & 2,06 & 9,45 & $-6,44 *$ & $-21,26$ & $-0,91$ & $-3,67$ \\
\hline $9 \times 3$ & $-1,60$ & $-6,30$ & 1,99 & 9,13 & $-5,19 *$ & $-17,92$ & $-0,98$ & $-3,96$ \\
\hline $10 \times 3$ & $-0,69$ & $-2,73$ & 2,84 & 13,03 & $-4,22 *$ & $-14,63$ & $-0,13$ & $-0,52$ \\
\hline $5 \times 4$ & $-0,13$ & $-0,61$ & $4,25 *$ & 26,40 & $-4,50 *$ & $-18,11$ & $-4,41$ & $-17,81$ \\
\hline $6 \times 4$ & 2,10 & 10,12 & $6,69 *$ & 41,55 & $-2,50$ & $-9,89$ & $-1,97$ & $-7,96$ \\
\hline $7 \times 4$ & $2,96 *$ & 14,22 & $7,63^{*}$ & 47,39 & $-1,72$ & $-6,76$ & $-1,03$ & $-4,16$ \\
\hline $8 \times 4$ & $-0,61$ & $-2,61$ & $6,49 *$ & 40,31 & $-7,70^{*}$ & $-25,42$ & $-2,17$ & $-8,76$ \\
\hline $9 \times 4$ & $-1,58$ & $-6,99$ & $4,86^{*}$ & 30,19 & $-8,01 *$ & $-27,65$ & $-3,80$ & $-15,35$ \\
\hline $10 \times 4$ & $-2,34$ & $-10,39$ & $4,04 *$ & 25,09 & $-8,71 *$ & $-30,19$ & $-4,96$ & $-20,03$ \\
\hline
\end{tabular}

a/ heteroses (MG, GRPVY, GSPVY) : teste t a 5\% de probabilidade

b/ heterose (HP) : teste de Dunnet a 5\% de probabilidade 
Tabela 13. Heterose em relação à média dos genitores (MG), em relação ao genitor resistente ao PVY (GRPVY), em relação ao genitor suscetível ao PVY (GSPVY) e em relação ao híbrido padrão (HP) para o caráter peso médio de fruto.

\begin{tabular}{|c|c|c|c|c|c|c|c|c|}
\hline \multirow[b]{2}{*}{ Híbrido } & \multicolumn{2}{|c|}{$\begin{array}{c}\text { heterose } \\
\text { MG }^{\text {a/ }}\end{array}$} & \multicolumn{2}{|c|}{$\begin{array}{l}\text { heterose } \\
\text { GRPVY }^{\text {a/ }}\end{array}$} & \multicolumn{2}{|c|}{$\begin{array}{l}\text { heterose } \\
\text { GSPVY }^{a /}\end{array}$} & \multicolumn{2}{|c|}{$\begin{array}{c}\text { heterose } \\
\mathrm{HP}^{\mathrm{b} /}\end{array}$} \\
\hline & valor & $\%$ & valor & $\%$ & valor & $\%$ & valor & $\%$ \\
\hline $5 \times 1$ & $-0,90$ & $-0,50$ & 3,40 & 1,94 & $-5,20$ & $-2,82$ & 13,48 & 8,15 \\
\hline $6 \times 1$ & $-6,37$ & $-3,76$ & $-12,27^{*}$ & $-6,99$ & $-0,47$ & $-0,29$ & $-2,19$ & $-1,32$ \\
\hline $7 \times 1$ & $11,18^{*}$ & 6,04 & $20,73^{*}$ & 11,81 & 1,63 & 0,84 & $30,81^{*}$ & 18,62 \\
\hline $8 \times 1$ & $8,65^{*}$ & 5,09 & 3,00 & 1,71 & $14,30 *$ & 8,71 & 13,08 & 7,91 \\
\hline $9 \times 1$ & 1,44 & 0,84 & $-2,23$ & $-1,27$ & 5,10 & 3,03 & 7,85 & 4,74 \\
\hline 10x1 & $17,25^{*}$ & 10,67 & 3,46 & 1,97 & $31,04 *$ & 20,98 & 13,54 & 8,18 \\
\hline $5 \times 2$ & 9,63* & 5,21 & $9,13^{*}$ & 4,93 & $10,12 *$ & 5,50 & $28,80^{*}$ & 17,41 \\
\hline $6 \times 2$ & 0,11 & 0,06 & $-10,59 *$ & $-5,72$ & $10,80 *$ & 6,60 & 9,08 & 5,49 \\
\hline $7 \times 2$ & $15,26 *$ & 8,03 & $20,01^{*}$ & 10,81 & $10,50 *$ & 5,40 & $39,68 *$ & 23,98 \\
\hline $8 \times 2$ & $11,17^{*}$ & 6,39 & 0,72 & 0,39 & $21,61^{*}$ & 13,16 & $20,39 *$ & 12,32 \\
\hline $9 \times 2$ & 1,49 & 0,84 & $-6,97 *$ & $-3,77$ & $9,95 *$ & 5,92 & 12,70 & 7,68 \\
\hline $10 \times 2$ & 5,29 & 3,17 & $-13,30 *$ & $-7,19$ & $23,87^{*}$ & 16,13 & 6,37 & 3,85 \\
\hline $5 \times 3$ & $21,72^{*}$ & 11,66 & $19,54^{*}$ & 10,37 & $23,89 *$ & 12,98 & $42,57 *$ & 25,73 \\
\hline $6 \times 3$ & $-6,37$ & $-3,61$ & $-18,74^{*}$ & $-9,94$ & 6,01 & 3,67 & 4,29 & 2,59 \\
\hline $7 \times 3$ & $-17,61^{*}$ & $-9,19$ & $-14,53^{*}$ & $-7,71$ & $-20,68^{*}$ & $-10,63$ & 8,50 & 5,14 \\
\hline $8 \times 3$ & 3,36 & 1,90 & $-8,77$ & $-4,65$ & $15,48^{*}$ & 9,43 & 14,26 & 8,62 \\
\hline $9 \times 3$ & $-4,68$ & $-2,62$ & $-14,82 *$ & $-7,86$ & 5,46 & 3,25 & 8,21 & 4,96 \\
\hline $10 \times 3$ & $12,03^{*}$ & 7,15 & $-8,24$ & $-4,37$ & $32,29 *$ & 21,83 & 14,79 & 8,94 \\
\hline $5 \times 4$ & $18,29 *$ & 10,03 & $20,09 *$ & 11,13 & $16,49 *$ & 8,96 & $35,17^{*}$ & 21,26 \\
\hline $6 \times 4$ & 1,75 & 1,02 & $-6,65$ & $-3,68$ & $10,15^{*}$ & 6,20 & 8,43 & 5,09 \\
\hline $7 \times 4$ & $8,87 *$ & 4,73 & $15,92^{*}$ & 8,82 & 1,82 & 0,94 & $31,00^{*}$ & 18,74 \\
\hline $8 \times 4$ & 3,62 & 2,10 & $-4,53$ & $-2,51$ & $11,77^{*}$ & 7,17 & 10,55 & 6,38 \\
\hline $9 \times 4$ & 9,63 & 5,52 & 3,46 & 1,92 & $15,79 *$ & 9,39 & 18,45 & 11,15 \\
\hline $10 \times 4$ & $29,66^{*}$ & 18,06 & $13,37^{*}$ & 7,41 & $45,95^{*}$ & 31,06 & $28,45^{*}$ & 17,19 \\
\hline
\end{tabular}

a/ heteroses (MG, GRPVY, GSPVY) : teste t a $5 \%$ de probabilidade

b/ heterose (HP) : teste de Dunnet a 5\% de probabilidade 
Foram também observados valores significativos de heterobeltiose variando de 4,93\% (híbrido 5x2) a 10,37\% (híbrido 5x3), Tabela 13. Outros autores como Ahmed \& Muzafar (2000) e Mamedov \& Pyshnaja (2001) observaram em pimentão valores maiores de heterobeltiose para o caráter PMF.

\subsubsection{Comprimento de fruto}

O comprimento de fruto $(\mathrm{CF})$ é um caráter importante, pois participa da definição do formato do fruto, que é fundamental para a determinação do grupo ao qual ele pertence, ou seja : cônico, cônico alongado, quadrado ou retangular. Além disso, o comprimento de fruto participa da definição do tamanho do fruto. Estes dois aspectos aliados são importantes para a determinação do número de frutos necessários para o preenchimento de uma caixa "K".

Para o CF os valores dos híbridos variaram entre 12,74 (6x4) e 17,99 cm (7x4), sendo que nenhum dos híbridos apresentou CF significativamente maior do que o do HP (teste de Dunnett, Tabela 7), que apresentou frutos com 17,05 cm. De fato, Magali-R possui frutos bastante alongados, o que tem sido motivo de queixas em alguns mercados nos quais se prefere frutos mais curtos. Sendo assim, seriam interessantes híbridos com menor CF do que o híbridopadrão. De fato, foram encontrados diversos híbridos com $\mathrm{CF}$ significativamente menor que o de Magali-R (Tabela 7). Desta forma, foram observados valores significativos de heterose-padrão negativa de $-11,32$ (híbrido 9x2) a -25,28\% (híbrido 6x4), Tabela 14.

Valores significativos de heteroses negativa e positiva foram encontrados em relação à $\mathrm{MG}$, variando de -12,52 (híbrido 6x1) a 19,53\% 
Tabela 14. Heterose em relação à média dos genitores (MG), em relação ao genitor resistente ao PVY (GRPVY), em relação ao genitor suscetível ao PVY (GSPVY) e em relação ao híbrido padrão (HP) para o caráter comprimento de fruto.

\begin{tabular}{|c|c|c|c|c|c|c|c|c|}
\hline \multirow[b]{2}{*}{ Híbrido } & \multicolumn{2}{|c|}{$\begin{array}{c}\text { heterose } \\
\text { MG }^{\mathrm{a}}\end{array}$} & \multicolumn{2}{|c|}{$\begin{array}{l}\text { heterose } \\
\text { GRPVY }^{\text {al }}\end{array}$} & \multicolumn{2}{|c|}{$\begin{array}{l}\text { heterose } \\
\text { GSPVY }^{a /}\end{array}$} & \multicolumn{2}{|c|}{$\begin{array}{c}\text { heterose } \\
\mathrm{HP}^{\mathrm{b} /}\end{array}$} \\
\hline & valor & $\%$ & valor & $\%$ & valor & $\%$ & valor & $\%$ \\
\hline $5 \times 1$ & $0,88^{*}$ & 5,94 & 0,10 & 0,64 & $1,66^{*}$ & 11,82 & $-1,35$ & $-7,92$ \\
\hline $6 \times 1$ & $-1,83^{*}$ & $-12,52$ & $-2,85^{*}$ & $-18,27$ & $-0,80 *$ & $-5,90$ & $-4,03 *$ & $-23,64$ \\
\hline $7 \times 1$ & 0,49 & 2,82 & $2,08^{*}$ & 13,33 & $-1,11^{*}$ & $-5,91$ & 0,63 & 3,69 \\
\hline $8 \times 1$ & 0,00 & 0,00 & $-2,05^{*}$ & $-13,14$ & $2,05^{*}$ & 17,83 & $-3,50 *$ & $-20,53$ \\
\hline $9 \times 1$ & $1,49 *$ & 9,97 & 0,78 & 5,00 & $2,19 *$ & 15,43 & $-0,67$ & $-3,93$ \\
\hline $10 \times 1$ & $2,22 *$ & 14,10 & $2,37 *$ & 15,19 & $2,07 *$ & 13,02 & 0,92 & 5,40 \\
\hline $5 \times 2$ & $0,92^{*}$ & 6,49 & $0,86^{*}$ & 6,08 & $0,97 *$ & 6,91 & $-2,04 *$ & $-11,96$ \\
\hline $6 \times 2$ & $-0,86 *$ & $-6,21$ & $-1,16^{*}$ & $-8,20$ & $-0,56$ & $-4,13$ & $-4,06^{*}$ & $-23,81$ \\
\hline $7 \times 2$ & $1,18^{*}$ & 7,17 & $3,50 *$ & 24,74 & $-1,14^{*}$ & $-6,07$ & 0,60 & 3,52 \\
\hline $8 \times 2$ & $1,38^{*}$ & 10,72 & 0,05 & 0,35 & $2,70 *$ & 23,48 & $-2,85^{*}$ & $-16,71$ \\
\hline $9 \times 2$ & $0,95^{*}$ & 6,70 & $0,97 *$ & 6,86 & $0,93 *$ & 6,55 & $-1,93 *$ & $-11,32$ \\
\hline $10 \times 2$ & $2,30 *$ & 15,28 & $3,17 *$ & 22,40 & $1,42 *$ & 8,93 & 0,27 & 1,58 \\
\hline $5 \times 3$ & $2,84 *$ & 19,53 & $2,36^{*}$ & 15,74 & $3,31 *$ & 23,58 & 0,30 & 1,76 \\
\hline $6 \times 3$ & $-0,52$ & $-3,64$ & $-1,24^{*}$ & $-8,27$ & 0,20 & 1,48 & $-3,30 *$ & $-19,35$ \\
\hline $7 \times 3$ & $-0,66$ & $-3,91$ & $1,24^{*}$ & 8,27 & $-2,56 *$ & $-13,62$ & $-0,82$ & $-4,81$ \\
\hline $8 \times 3$ & 0,29 & 2,15 & $-1,46^{*}$ & $-9,74$ & $2,03 *$ & 17,65 & $-3,52 *$ & $-20,64$ \\
\hline $9 \times 3$ & $2,63^{*}$ & 18,03 & $2,23 *$ & 14,88 & $3,03^{*}$ & 21,35 & 0,17 & 1,00 \\
\hline $10 \times 3$ & $2,03^{*}$ & 13,11 & $2,48^{*}$ & 16,54 & $1,57 *$ & 9,87 & 0,42 & 2,46 \\
\hline $5 \times 4$ & $-0,98^{*}$ & $-7,07$ & $-0,72$ & $-5,32$ & $-1,23^{*}$ & $-8,76$ & $-4,24 *$ & $-24,87$ \\
\hline $6 \times 4$ & $-0,80^{*}$ & $-5,91$ & $-0,79$ & $-5,84$ & $-0,81^{*}$ & $-5,98$ & $-4,31 *$ & $-25,28$ \\
\hline $7 \times 4$ & $1,83^{*}$ & 11,32 & $4,46^{*}$ & 32,96 & $-0,80^{*}$ & $-4,26$ & 0,94 & 5,51 \\
\hline $8 \times 4$ & $1,50^{*}$ & 11,95 & 0,48 & 3,55 & $2,51 *$ & 21,83 & $-3,04 *$ & $-17,83$ \\
\hline $9 \times 4$ & $1,90^{*}$ & 13,71 & $2,23^{*}$ & 16,48 & $1,57 *$ & 11,06 & $-1,29$ & $-7,56$ \\
\hline $10 \times 4$ & $0,72 *$ & 4,86 & $1,90 *$ & 14,04 & $-0,47$ & $-2,96$ & $-1,62$ & $-9,50$ \\
\hline
\end{tabular}

a/ heteroses (MG, GRPVY, GSPVY) : teste t a 5\% de probabilidade

b/ heterose (HP) : teste de Dunnet a 5\% de probabilidade 
(híbrido 5x3), Tabela 14. Panayatov et al. (2000) relataram também terem encontrado heterose para CF em pimentão.

Heterobeltioses significativas, tanto positivas quanto negativas, também foram encontradas : -5,90\% (híbrido 6x1) e 15,74\% (híbrido 5x3), Tabela 14. Este fato mostra que o $\mathrm{CF}$ dos híbridos é relativamente independente do CF dos genitores; portanto, é possível obter híbridos de frutos mais curtos mesmo quando ambos ou um dos genitores possuir frutos demasiadamente alongados e vice-versa. Heterobeltiose de $29,03 \%$ foi encontrada por Ahmed \& Muzafar Hurra (2000) em pimentão.

\subsubsection{Diâmetro de fruto}

Assim como o comprimento, o diâmetro de fruto (DF) também é um caráter importante por participar da definição do formato e do tamanho do fruto.

O híbrido-padrão foi o tratamento que apresentou o menor valor de diâmetro de fruto neste trabalho, ou seja, $6,87 \mathrm{~cm}$. Uma das críticas existentes em alguns mercados em relação a "Magali-R" é o seu diâmetro de fruto relativamente estreito. Em função disso, diversos híbridos apresentaram valores significativamente superiores ao do $\mathrm{HP}$, variando de 7,69 cm (híbrido 7x1) a 8,49 cm (híbrido 5x4), pelo teste de Dunnett (Tabela 7). Valores de heterose-padrão de 11,94 (híbrido 7x1) a 23,58\% (híbrido 5x4) foram observados (Tabela 15).

Um valor significativo máximo de heterose de 5,79\% em relação à MG foi observado no híbrido 5x4 (Tabela 15). Valores positivos de heterose também foram encontrados por Panayotov (2000) em pimentão para largura de fruto. 
Tabela 15. Heterose em relação à média dos genitores (MG), em relação ao genitor resistente ao PVY (GRPVY), em relação ao genitor suscetível ao PVY (GSPVY) e em relação ao híbrido padrão (HP) para o caráter diâmetro de fruto.

\begin{tabular}{|c|c|c|c|c|c|c|c|c|}
\hline \multirow[b]{2}{*}{ Híbrido } & \multicolumn{2}{|c|}{$\begin{array}{c}\text { heterose } \\
\text { MG }^{\mathrm{a}}\end{array}$} & \multicolumn{2}{|c|}{$\begin{array}{l}\text { heterose } \\
\text { GRPVY }^{\text {a/ }}\end{array}$} & \multicolumn{2}{|c|}{$\begin{array}{l}\text { heterose } \\
\text { GSPVY }^{\text {al }}\end{array}$} & \multicolumn{2}{|c|}{$\begin{array}{c}\text { heterose } \\
\mathrm{HP}^{\mathrm{b} /}\end{array}$} \\
\hline & valor & $\%$ & valor & $\%$ & valor & $\%$ & valor & $\%$ \\
\hline $5 \times 1$ & $-0,25$ & $-3,22$ & 0,00 & 0,00 & $-0,50^{*}$ & $-6,24$ & 0,64 & 9,32 \\
\hline $6 \times 1$ & $-0,08$ & $-0,99$ & 0,00 & 0,00 & $-0,15$ & $-1,96$ & 0,64 & 9,32 \\
\hline $7 \times 1$ & 0,04 & 0,52 & 0,18 & 2,40 & $-0,10$ & $-1,28$ & $0,82^{*}$ & 11,94 \\
\hline $8 \times 1$ & $-0,20$ & $-2,53$ & 0,21 & 2,80 & $-0,61^{*}$ & $-7,32$ & $0,85^{*}$ & 12,37 \\
\hline $9 \times 1$ & 0,04 & 0,54 & $-0,02$ & $-0,27$ & 0,10 & 1,35 & 0,62 & 9,02 \\
\hline $10 \times 1$ & $-0,49 *$ & $-6,61$ & $-0,59 *$ & $-7,86$ & $-0,39 *$ & $-5,34$ & 0,05 & 0,73 \\
\hline $5 \times 2$ & $-0,50 *$ & $-6,23$ & $-0,51^{*}$ & $-6,35$ & $-0,49 *$ & $-6,12$ & 0,65 & 9,46 \\
\hline $6 \times 2$ & 0,24 & 3,00 & 0,05 & 0,62 & $0,42 *$ & 5,48 & $1,21^{*}$ & 17,61 \\
\hline $7 \times 2$ & $-0,04$ & $-0,51$ & $-0,16$ & $-1,99$ & 0,08 & 1,03 & $1,00 *$ & 14,56 \\
\hline $8 \times 2$ & 0,01 & 0,12 & 0,16 & 1,99 & $-0,14$ & $-1,68$ & $1,32 *$ & 19,21 \\
\hline $9 \times 2$ & $-0,14$ & $-1,82$ & $-0,46^{*}$ & $-5,73$ & 0,18 & 2,44 & 0,70 & 10,19 \\
\hline $10 \times 2$ & $-0,47^{*}$ & $-6,13$ & $-0,83^{*}$ & $-10,34$ & $-0,11$ & $-1,51$ & 0,33 & 4,80 \\
\hline $5 \times 3$ & $-0,01$ & $-0,13$ & 0,17 & 2,22 & $-0,19$ & $-2,37$ & $0,95^{*}$ & 13,83 \\
\hline $6 \times 3$ & $-0,16$ & $-2,03$ & $-0,15$ & $-1,96$ & $-0,16$ & $-2,09$ & 0,63 & 9,17 \\
\hline $7 \times 3$ & $-0,18$ & $-2,33$ & $-0,11$ & $-1,44$ & $-0,25$ & $-3,21$ & 0,67 & 9,75 \\
\hline $8 \times 3$ & $-0,21$ & $-2,63$ & 0,13 & 1,70 & $-0,55^{*}$ & $-6,60$ & $0,91^{*}$ & 13,25 \\
\hline $9 \times 3$ & $-0,11$ & $-1,46$ & $-0,24$ & $-3,14$ & 0,02 & 0,27 & 0,54 & 7,86 \\
\hline $10 \times 3$ & $-0,34^{*}$ & $-4,55$ & $-0,51 *$ & $-6,67$ & $-0,17$ & $-2,33$ & 0,27 & 3,93 \\
\hline $5 \times 4$ & $0,47 *$ & 5,79 & $0,45^{*}$ & 5,60 & $0,48^{*}$ & 5,99 & $1,62 *$ & 23,58 \\
\hline $6 \times 4$ & 0,16 & 2,04 & $-0,03$ & $-0,37$ & $0,35^{*}$ & 4,57 & $1,14^{*}$ & 16,59 \\
\hline $7 \times 4$ & $-0,03$ & $-0,32$ & $-0,15$ & $-1,87$ & 0,10 & 1,28 & $1,02 *$ & 14,85 \\
\hline $8 \times 4$ & $-0,31^{*}$ & $-3,73$ & $-0,16$ & $-1,99$ & $-0,45^{*}$ & $-5,40$ & $1,01 *$ & 14,70 \\
\hline $9 \times 4$ & $0,38^{*}$ & 4,86 & 0,05 & 0,62 & $0,70^{*}$ & 9,47 & $1,22 *$ & 17,76 \\
\hline $10 \times 4$ & 0,26 & 3,32 & $-0,11$ & $-1,37$ & $0,62 *$ & 8,48 & $1,06 *$ & 15,43 \\
\hline
\end{tabular}

a/ heteroses (MG, GRPVY, GSPVY) : teste t a 5\% de probabilidade

b/ heterose (HP) : teste de Dunnet a 5\% de probabilidade 
O híbrido $5 \times 4$ mostrou ainda significativo valor de heterobeltiose (5,60\%), Tabela 15. Ahmed \& Muzafar Hurra (2000) também encontraram valores significativos de heterobeltiose para o caráter largura de fruto em pimentão.

\subsubsection{Espessura de pericarpo de fruto}

O caráter espessura de pericarpo (EP) tem uma grande participação na determinação do peso dos frutos de pimentão. Além disso, a EP apresenta uma grande importância na conservação pós-colheita dos frutos de pimentão, pois, de maneira geral, quanto maior for a $\mathrm{EP}$, menos intenso será o processo de murchamento dos frutos.

O híbrido Magali-R sabidamente possui espessura de pericarpo mais fina do que o desejável. Isto pode ser comprovado pelos dados da Tabela 7 , que indicam ser o híbrido-padrão o tratamento que possui a espessura de polpa mais fina $(4,64 \mathrm{~mm})$. Sendo assim, pode-se identificar vários híbridos significativamente superiores a Magali- $R$, os quais apresentam valores de espessura de pericarpo que variam de 5,68 mm (5x4) a 6,17 mm (10x4), Tabela 7. Portanto, foi possível obter heterose-padrão significativamente maiores que Magali-R (Tabela 16) em alguns híbridos como por exemplo : $10 x 2(28,23 \%), 10 x 3(31,90 \%)$ e $10 \times 4(32,97 \%)$.

Observou-se heterose significativa em relação à MG para os híbridos 10x4 (8,06\%) e 10x3 (9,38\%), Tabela 16. Panayotov et al. (2000) também observaram valores positivos de heterose para EP em pimentão.

Valores significativos na faixa de 8,97 (híbrido 10x2) a 18,38\% (híbrido 10x3) de heterose, em relação aos GRPVY, para EP também foram encontrados, Tabela 16. Foram observados diversos valores de heterose 
Tabela 16. Heterose em relação à média dos genitores (MG), em relação ao genitor resistente ao PVY (GRPVY), em relação ao genitor suscetível ao PVY (GSPVY) e em relação ao híbrido padrão (HP) para o caráter espessura de pericarpo de fruto.

\begin{tabular}{|c|c|c|c|c|c|c|c|c|}
\hline \multirow[b]{2}{*}{ Híbrido } & \multicolumn{2}{|c|}{$\begin{array}{c}\text { heterose } \\
\text { MG }^{\text {a/ }}\end{array}$} & \multicolumn{2}{|c|}{$\begin{array}{l}\text { heterose } \\
\text { GRPVY }^{\text {al }}\end{array}$} & \multicolumn{2}{|c|}{$\begin{array}{l}\text { heterose } \\
\text { GSPVY }^{\text {al }}\end{array}$} & \multicolumn{2}{|c|}{$\begin{array}{c}\text { heterose } \\
\mathrm{HP}^{\mathrm{b} /}\end{array}$} \\
\hline & valor & $\%$ & valor & $\%$ & valor & $\%$ & valor & $\%$ \\
\hline $5 \times 1$ & 0,01 & 0,09 & $0,48^{*}$ & 9,62 & $-0,47^{*}$ & $-7,91$ & 0,83 & 17,89 \\
\hline $6 \times 1$ & 0,20 & 3,85 & 0,41 & 8,22 & $-0,01$ & $-0,19$ & 0,76 & 16,38 \\
\hline $7 \times 1$ & 0,07 & 1,27 & $0,61^{*}$ & 12,22 & $-0,47 *$ & $-7,74$ & 0,96 & 20,69 \\
\hline $8 \times 1$ & $-0,10$ & $-1,86$ & 0,01 & 0,20 & $-0,20$ & $-3,85$ & 0,36 & 7,76 \\
\hline $9 \times 1$ & $-0,10$ & $-1,80$ & 0,18 & 3,61 & $-0,37$ & $-6,68$ & 0,53 & 11,42 \\
\hline $10 \times 1$ & $-0,01$ & $-0,09$ & $0,51^{*}$ & 10,22 & $-0,52 *$ & $-8,64$ & 0,86 & 18,53 \\
\hline $5 \times 2$ & $-0,09$ & $-1,58$ & 0,15 & 2,75 & $-0,33$ & $-5,56$ & 0,97 & 20,90 \\
\hline $6 \times 2$ & $-0,06$ & $-1,01$ & $-0,08$ & $-1,47$ & $-0,03$ & $-0,56$ & 0,74 & 15,95 \\
\hline $7 \times 2$ & $-0,17$ & $-2,86$ & 0,14 & 2,56 & $-0,47 *$ & $-7,74$ & 0,96 & 20,69 \\
\hline $8 \times 2$ & 0,02 & 0,38 & $-0,11$ & $-2,02$ & 0,15 & 2,89 & 0,71 & 15,30 \\
\hline $9 \times 2$ & $-0,20$ & $-3,64$ & $-0,16$ & $-2,93$ & $-0,24$ & $-4,33$ & 0,66 & 14,22 \\
\hline $10 \times 2$ & 0,21 & 3,66 & $0,49 *$ & 8,97 & $-0,07$ & $-1,16$ & $1,31^{*}$ & 28,23 \\
\hline $5 \times 3$ & $-0,03$ & $-0,45$ & 0,36 & 6,96 & $-0,41$ & $-6,90$ & 0,89 & 19,18 \\
\hline $6 \times 3$ & $-0,23$ & $-4,35$ & $-0,11$ & $-2,13$ & $-0,35$ & $-6,47$ & 0,42 & 9,05 \\
\hline $7 \times 3$ & $-0,82^{*}$ & $-14,59$ & $-0,37$ & $-7,16$ & $-1,27^{*}$ & $-20,92$ & 0,16 & 3,45 \\
\hline $8 \times 3$ & $-0,03$ & $-0,48$ & $-0,01$ & $-0,19$ & $-0,04$ & $-0,77$ & 0,52 & 11,21 \\
\hline $9 \times 3$ & $-0,22$ & $-4,02$ & $-0,03$ & $-0,58$ & $-0,40$ & $-7,22$ & 0,50 & 10,78 \\
\hline $10 \times 3$ & $0,53 *$ & 9,38 & $0,95 *$ & 18,38 & 0,10 & 1,66 & $1,48^{*}$ & 31,90 \\
\hline $5 \times 4$ & 0,01 & 0,18 & 0,28 & 5,19 & $-0,26$ & $-4,38$ & 1,04 & 22,41 \\
\hline $6 \times 4$ & 0,03 & 0,46 & 0,03 & 0,56 & 0,02 & 0,37 & 0,79 & 17,03 \\
\hline $7 \times 4$ & $-0,18$ & $-3,05$ & 0,16 & 2,96 & $-0,51 *$ & $-8,40$ & 0,92 & 19,83 \\
\hline $8 \times 4$ & 0,16 & 3,02 & 0,06 & 1,11 & 0,26 & 5,00 & 0,82 & 17,67 \\
\hline $9 \times 4$ & 0,02 & 0,37 & 0,09 & 1,67 & $-0,05$ & $-0,90$ & 0,85 & 18,32 \\
\hline $10 \times 4$ & $0,46^{*}$ & 8,06 & $0,77^{*}$ & 14,26 & 0,15 & 2,49 & $1,53^{*}$ & 32,97 \\
\hline
\end{tabular}

a/ heteroses (MG, GRPVY, GSPVY) : teste t a 5\% de probabilidade

b/ heterose (HP) : teste de Dunnet a 5\% de probabilidade 
negativa significativa para EP, em relação aos GSPVY, indicando haver neste grupo vários genitores com boa espessura de pericarpo.

\subsubsection{Número de lóculos por fruto}

A importância do número de lóculos (NL) por fruto está no fato do mesmo ser um dos fatores responsáveis pela definição do formato do fruto de pimentão, ou seja, frutos com predominância de três lóculos tendem a ser cônicos, ao passo que frutos com quatro lóculos tendem a ser quadrados ou retangulares.

Com exceção dos híbridos 6x3 e 8x3 que apresentaram médias de 3,02 e 3,25 lóculos por fruto, respectivamente, todos os demais apresentaram NL maior que o do híbrido-padrão, o qual obteve 3,29 lóculos por fruto. Porém, apenas o híbrido 10x4 que apresentou 3,82 lóculos por fruto diferiu significativamente dos demais, pelo teste de Dunnett (Tabela 7), inclusive apresentando heterose significativa em relação a Magali-R de 13,35\% (Tabela 17). Este mesmo híbrido apresentou, também, heterose positiva e significativa em relação à MG (6,11\%), Tabela 17. Miranda (1987) também obteve baixos valores $(6,5$ e $8,2 \%)$ de heterose positiva para NL por fruto em pimentão.

Valores significativamente positivos de heterose em relação aos GSPVY foram observados nos híbridos $5 \times 2$ (8,70\%), 6x2 (8,57\%), 5x4 $(7,25 \%), 6 \times 4(7,94 \%)$ e 10x4 (7,61\%), Tabela 17.

Diversos valores de heterose negativa significativa para esse caráter foram observados, em relação aos GRPVY, o que é um indicativo de que neste grupo estão presentes vários genitores com uma elevada média de número de lóculos por fruto, Tabela 17. 
Tabela 17. Heterose em relação à média dos genitores (MG), em relação ao genitor resistente ao PVY (GRPVY), em relação ao genitor suscetível ao PVY (GSPVY) e em relação ao híbrido padrão (HP ) para o caráter número de lóculos por fruto.

\begin{tabular}{|c|c|c|c|c|c|c|c|c|}
\hline \multirow[b]{2}{*}{ Híbrido } & \multicolumn{2}{|c|}{$\begin{array}{c}\text { heterose } \\
\text { MG }^{\text {a/ }}\end{array}$} & \multicolumn{2}{|c|}{$\begin{array}{l}\text { heterose } \\
\text { GRPVY }^{\text {a/ }}\end{array}$} & \multicolumn{2}{|c|}{$\begin{array}{l}\text { heterose } \\
\text { GSPVY }^{\text {a/ }}\end{array}$} & \multicolumn{2}{|c|}{$\begin{array}{c}\text { heterose } \\
\qquad \mathrm{HP}^{\mathrm{b} /}\end{array}$} \\
\hline & valor & $\%$ & valor & $\%$ & valor & $\%$ & valor & $\%$ \\
\hline $5 \times 1$ & $-0,09$ & $-2,49$ & $-0,25^{*}$ & $-6,63$ & 0,07 & 2,03 & 0,15 & 4,45 \\
\hline $6 \times 1$ & $-0,09$ & $-2,60$ & $-0,40^{*}$ & $-10,61$ & 0,22 & 6,98 & 0,00 & 0,00 \\
\hline $7 \times 1$ & $-0,12$ & $-3,30$ & $-0,40^{*}$ & $-10,61$ & 0,17 & 5,31 & 0,00 & 0,00 \\
\hline $8 \times 1$ & 0,03 & 0,69 & $-0,10$ & $-2,65$ & 0,15 & 4,26 & 0,30 & 8,90 \\
\hline $9 \times 1$ & 0,00 & 0,00 & $-0,05$ & $-1,33$ & 0,05 & 1,36 & 0,35 & 10,39 \\
\hline $10 \times 1$ & 0,09 & 2,46 & $-0,02$ & $-0,53$ & 0,20 & 5,63 & 0,38 & 11,28 \\
\hline $5 \times 2$ & 0,09 & 2,46 & $-0,12$ & $-3,10$ & $0,30 *$ & 8,70 & 0,38 & 11,28 \\
\hline $6 \times 2$ & $-0,09$ & $-2,56$ & $-0,45^{*}$ & $-11,63$ & $0,27 *$ & 8,57 & 0,05 & 1,48 \\
\hline $7 \times 2$ & $-0,19$ & $-5,23$ & $-0,52 *$ & $-13,44$ & 0,15 & 4,69 & $-0,02$ & $-0,59$ \\
\hline $8 \times 2$ & $-0,18$ & $-4,74$ & $-0,35^{*}$ & $-9,04$ & 0,00 & 0,00 & 0,15 & 4,45 \\
\hline $9 \times 2$ & $-0,05$ & $-1,33$ & $-0,15$ & $-3,88$ & 0,05 & 1,36 & 0,35 & 10,39 \\
\hline $10 \times 2$ & $-0,14$ & $-3,77$ & $-0,30 *$ & $-7,75$ & 0,02 & 0,56 & 0,20 & 5,93 \\
\hline $5 \times 3$ & $-0,06$ & $-1,56$ & $-0,13$ & $-3,61$ & 0,02 & 0,58 & 0,10 & 2,97 \\
\hline $6 \times 3$ & $-0,36 *$ & $-10,52$ & $-0,58^{*}$ & $-16,11$ & $-0,13$ & $-4,13$ & $-0,35$ & $-10,39$ \\
\hline $7 \times 3$ & $-0,03$ & $-0,88$ & $-0,23$ & $-6,39$ & 0,17 & 5,31 & 0,00 & 0,00 \\
\hline $8 \times 3$ & $-0,31 *$ & $-8,71$ & $-0,35 *$ & $-9,72$ & $-0,27^{*}$ & $-7,67$ & $-0,12$ & $-3,56$ \\
\hline $9 \times 3$ & $-0,19$ & $-5,09$ & $-0,15$ & $-4,17$ & $-0,22$ & $-6,00$ & 0,08 & 2,37 \\
\hline $10 \times 3$ & 0,15 & 4,06 & 0,12 & 3,33 & 0,17 & 4,79 & 0,35 & 10,39 \\
\hline $5 \times 4$ & 0,15 & 4,23 & 0,05 & 1,37 & $0,25^{*}$ & 7,25 & 0,33 & 9,79 \\
\hline $6 \times 4$ & 0,00 & 0,00 & $-0,25$ & $-6,85$ & $0,25^{*}$ & 7,94 & 0,03 & 0,89 \\
\hline $7 \times 4$ & $-0,06$ & $-1,61$ & $-0,28$ & $-7,67$ & 0,17 & 5,31 & 0,00 & 0,00 \\
\hline $8 \times 4$ & $-0,17$ & $-4,60$ & $-0,23$ & $-6,30$ & $-0,10$ & $-2,84$ & 0,05 & 1,48 \\
\hline $9 \times 4$ & $-0,11$ & $-3,01$ & $-0,10$ & $-2,74$ & $-0,12$ & $-3,27$ & 0,18 & 5,34 \\
\hline $10 \times 4$ & $0,22 *$ & 6,11 & 0,17 & 4,66 & $0,27 *$ & 7,61 & $0,45^{*}$ & 13,35 \\
\hline
\end{tabular}

a/ heteroses (MG, GRPVY, GSPVY) : teste t a 5\% de probabilidade

b/ heterose (HP) : teste de Dunnet a 5\% de probabilidade 


\subsection{Ação gênica}

A análise de variância com os desdobramentos dos quadrados médios pelo método de Gardner \& Eberhart (1966) adaptado por Miranda Filho \& Geraldi (1984), tabela 5, revela significância para heterose apenas para altura de planta na maturidade, peso médio de fruto e comprimento de fruto, o que indica haver valores significativos para CGC (heterose gerada pelo grupo 2) e CEC (heterose específica).

\subsubsection{Altura de planta na maturidade}

Para o caráter altura de planta na maturidade (APM) houve a participação tanto de efeitos gênicos aditivos como não-aditivos, ambos diminuindo o caráter, com predominância dos primeiros (Tabela 18). Resultados semelhantes foram encontrados por outros autores : Doshi \& Shukla (2000b) que trabalharam com cruzamentos envolvendo pimentões e pimentas e Patel (1998) que trabalhou com pimenta.

Os genitores $1,2,7,8$ e 10 apresentaram valores positivos de capacidade geral de combinação ( ), sendo que o genitor 7 foi o responsável pelo maior aumento do caráter $\left({ }_{7}=7,66\right)$. Os genitores $3,4,5,6$ e 9 apresentaram valores negativos de, sendo o genitor 6 o que mais diminuiu a $\operatorname{APM}\left({ }_{6}=-7,96\right)$, Tabela 18.

Os valores da capacidade específica de combinação ( ij) variaram de 4,50 (híbrido 8x4) a 4,42 (híbrido 5x3). Dentro desta faixa de variação, destacou-se o híbrido 8x2 com valor de ij=4,17, pois além de apresentar um alto valor de ij, os seus dois genitores apresentaram valores positivos de capacidade geral de combinação ( ${ }_{8}=1,04$ e ${ }_{2}=3,33$ ). Da mesma forma, os 
Tabela 18. Estimativas dos efeitos de média (u), de variedades"per se"( vi e vj ), de heterose varietal ( hi e hj ), das capacidades geral ( gi e gj ) e específica ( sij ) de combinação para o caráter altura de planta na maturidade.

\begin{tabular}{|c|c|c|c|c|}
\hline $\begin{array}{c}\text { média } \\
\mathrm{u}=73,46 \pm 0,74\end{array}$ & & $\begin{array}{l}\text { aditivc } \\
-7,46 \pm\end{array}$ & & $\begin{array}{l}\text { dominante } \\
h=-3,25 \pm 0,88\end{array}$ \\
\hline Genitor & vi & hi & gi & \\
\hline 1 & $-3,50$ & 2,71 & 0,96 & \\
\hline 2 & 12,00 & $-2,67$ & 3,33 & \\
\hline 3 & 1,00 & $-0,79$ & $-0,29$ & \\
\hline 4 & $-9,50$ & 0,75 & $-4,00$ & \\
\hline Erro padrão & 1,99 & 1,28 & & \\
\hline Genitor & vj & hj & gj & \\
\hline 5 & $-0,92$ & 0,37 & $-0,09$ & \\
\hline 6 & $-10,17$ & $-2,87$ & $-7,96$ & \\
\hline 7 & 5,83 & 4,75 & 7,66 & \\
\hline 8 & 2,58 & $-0,25$ & 1,04 & \\
\hline 9 & $-5,17$ & $-0,06$ & $-2,65$ & \\
\hline 10 & 7,83 & $-1,94$ & 1,98 & \\
\hline Erro padrão & 2,10 & 1,48 & & \\
\hline Híbrido & sij & & & \\
\hline $5 \times 1$ & 2,17 & & & \\
\hline $6 \times 1$ & $-0,96$ & & & \\
\hline $7 \times 1$ & $-0,33$ & & & \\
\hline $8 \times 1$ & 1,29 & & & \\
\hline $9 \times 1$ & $-0,02$ & & & \\
\hline $10 \times 1$ & $-2,15$ & & & \\
\hline $5 \times 2$ & $-2,21$ & & & \\
\hline $6 \times 2$ & $-0,08$ & & & \\
\hline $7 \times 2$ & 1,29 & & & \\
\hline $8 \times 2$ & 4,17 & & & \\
\hline $9 \times 2$ & $-3,40$ & & & \\
\hline $10 \times 2$ & 0,23 & & & \\
\hline $5 \times 3$ & 4,42 & & & \\
\hline $6 \times 3$ & $-2,46$ & & & \\
\hline $7 \times 3$ & $-3,83$ & & & \\
\hline $8 \times 3$ & $-0,96$ & & & \\
\hline $9 \times 3$ & $-0,02$ & & & \\
\hline $10 \times 3$ & 2,85 & & & \\
\hline $5 \times 4$ & $-4,37$ & & & \\
\hline $6 \times 4$ & 3,50 & & & \\
\hline $7 \times 4$ & 2,87 & & & \\
\hline $8 \times 4$ & $-4,50$ & & & \\
\hline $9 \times 4$ & 3,44 & & & \\
\hline $10 \times 4$ & $-0,94$ & & & \\
\hline Erro padrão & 1,82 & & & \\
\hline
\end{tabular}


híbridos 6x3 e 5x4 destacaram-se por apresentarem baixos valores de $\quad \mathrm{ij}=-2,46$ e $\mathrm{ij}=-4,37$, respectivamente; além disso, os genitores mostraram valores baixos de $\quad 6=-7,96, \quad{ }_{3}=-0,29, \quad 5=-0,09$ e $\quad{ }_{4}=-4,00$ (Tabela 18). É importante salientar que para APM pode-se também obter plantas mais altas ou mais baixas, através do manejo e das condições edafo-climáticas.

\subsubsection{Número de dias para o florescimento}

Em relação ao número de dias para o florescimento (NDF), tanto os efeitos gênicos aditivos quanto os não-aditivos, ambos diminuindo o caráter, estiveram presentes, sendo que os primeiros apresentaram uma maior magnitude (Tabela 19). Ahmed et al. (1997) e Vallejo et al. (1997) também encontraram em pimentão uma maior magnitude dos efeitos aditivos para NDF. O genitor 5 destacou-se com uma maior contribuição no sentido de diminuir o NDF com $\quad 5=-1,32$; além disso, o híbrido $8 \mathrm{x} 4$ apresentou o maior valor negativo de $\quad$ ij $(-1,80)$ para NDF (Tabela 19).

\subsubsection{Número de dias para a maturidade}

Com respeito ao número de dias para a maturidade (NDM), os efeitos não-aditivos, atuaram diminuindo o caráter e apresentaram magnitudes maiores que os aditivos (Tabela 20). Diversos autores obtiveram resultados semelhantes trabalhando com pimenta : Ahmed et al. (1998), Bhagyalakshmi et al. (1991) e Doshi \& Shukla (2000c). Dentre os genitores, o destaque foi

para o genitor 6, que apresentou o maior valor negativo de $\left({ }_{6}=-1,79\right)$. Valores negativos para NDM também foram encontrados nos híbridos, com destaque para 6x1 ( $\mathrm{ij}=-1,17)$ e $8 \times 4(\mathrm{ij}=-1,50)$, Tabela 20 . 
Tabela 19. Estimativas dos efeitos de média (u), de variedades"per se"( vi e vj ), de heterose varietal ( hi e hj ), das capacidades geral ( gi e gj ) e específica ( sij ) de combinaçi: para o caráter número de dias para o florescimento.

\begin{tabular}{|c|c|c|c|c|}
\hline $\begin{array}{c}\text { média } \\
\mathrm{u}=98,63 \pm 0,40\end{array}$ & & $\begin{array}{l}\text { aditivo } \\
-0,88 \pm\end{array}$ & & $\begin{array}{l}\text { dominante } \\
h=-0,55 \pm 0,47\end{array}$ \\
\hline Genitor & vi & hi & gi & \\
\hline 1 & 0,75 & $-0,32$ & 0,06 & \\
\hline 2 & 1,50 & $-0,86$ & $-0,11$ & \\
\hline 3 & 0,00 & $-0,36$ & $-0,36$ & \\
\hline 4 & $-2,25$ & 1,55 & 0,43 & \\
\hline Erro padrão & 1,06 & 0,68 & & \\
\hline Genitor & vj & hj & gj & \\
\hline 5 & $-1,50$ & $-0,57$ & $-1,32$ & \\
\hline 6 & $-0,50$ & $-0,14$ & $-0,39$ & \\
\hline 7 & 1,00 & 1,61 & 2,11 & \\
\hline 8 & 2,50 & $-0,95$ & 0,30 & \\
\hline 9 & 0,25 & $-0,45$ & $-0,33$ & \\
\hline 10 & $-1,75$ & 0,49 & $-0,39$ & \\
\hline Erro padrão & 1,12 & 0,79 & & \\
\hline Híbrido & sij & & & \\
\hline $5 \times 1$ & 1,20 & & & \\
\hline $6 \times 1$ & $-1,74$ & & & \\
\hline $7 \times 1$ & $-0,99$ & & & \\
\hline $8 \times 1$ & 1,07 & & & \\
\hline $9 \times 1$ & 1,20 & & & \\
\hline $10 \times 1$ & $-0,74$ & & & \\
\hline $5 \times 2$ & $-1,64$ & & & \\
\hline $6 \times 2$ & 0,68 & & & \\
\hline $7 \times 2$ & 1,68 & & & \\
\hline $8 \times 2$ & 0,24 & & & \\
\hline $9 \times 2$ & $-0,39$ & & & \\
\hline $10 \times 2$ & $-0,57$ & & & \\
\hline $5 \times 3$ & $-0,39$ & & & \\
\hline $6 \times 3$ & $-0,57$ & & & \\
\hline $7 \times 3$ & $-0,07$ & & & \\
\hline $8 \times 3$ & 0,49 & & & \\
\hline $9 \times 3$ & 0,37 & & & \\
\hline $10 \times 3$ & 0,18 & & & \\
\hline $5 \times 4$ & 0,82 & & & \\
\hline $6 \times 4$ & 1,64 & & & \\
\hline $7 \times 4$ & $-0,62$ & & & \\
\hline $8 \times 4$ & $-1,80$ & & & \\
\hline $9 \times 4$ & $-1,18$ & & & \\
\hline $10 \times 4$ & 1,14 & & & \\
\hline Erro padrão & 0,97 & & & \\
\hline
\end{tabular}


Tabela 20. Estimativas dos efeitos de média (u), de variedades"per se"( vi e vj ), de heterose varietal ( hi e hj ), das capacidades geral ( gi e gj ) e específica ( sij ) de combinaçi para o caráter número de dias para a maturidade.

\begin{tabular}{|c|c|c|c|c|}
\hline $\begin{array}{c}\text { média } \\
u=156,92 \pm 0,30\end{array}$ & & $\begin{aligned} & \text { aditivo } \\
= & 0,21 \pm C\end{aligned}$ & & $\begin{array}{l}\text { dominante } \\
h=-0,69 \pm 0,36\end{array}$ \\
\hline Genitor & vi & hi & gi & \\
\hline 1 & 1,37 & 0,04 & 0,73 & \\
\hline 2 & 0,87 & $-0,29$ & 0,15 & \\
\hline 3 & 1,12 & $-0,62$ & $-0,06$ & \\
\hline 4 & $-3,37$ & 0,87 & $-0,82$ & \\
\hline Erro padrão & 0,81 & 0,52 & & \\
\hline Genitor & vj & hj & gj & \\
\hline 5 & $-1,96$ & 0,25 & $-0,73$ & \\
\hline 6 & $-1,96$ & $-0,81$ & $-1,79$ & \\
\hline 7 & 4,54 & $-0,62$ & 1,65 & \\
\hline 8 & 0,04 & $-0,19$ & $-0,17$ & \\
\hline 9 & 2,54 & $-0,44$ & 0,83 & \\
\hline 10 & $-3,21$ & 1,81 & 0,21 & \\
\hline Erro padrão & 0,85 & 0,60 & & \\
\hline Híbrido & sij & & & \\
\hline $5 \times 1$ & 1,02 & & & \\
\hline $6 \times 1$ & $-1,17$ & & & \\
\hline $7 \times 1$ & 0,15 & & & \\
\hline $8 \times 1$ & 0,46 & & & \\
\hline $9 \times 1$ & $-0,29$ & & & \\
\hline $10 \times 1$ & $-0,17$ & & & \\
\hline $5 \times 2$ & $-0,65$ & & & \\
\hline $6 \times 2$ & $-0,08$ & & & \\
\hline $7 \times 2$ & 0,98 & & & \\
\hline $8 \times 2$ & $-0,46$ & & & \\
\hline $9 \times 2$ & 0,54 & & & \\
\hline $10 \times 2$ & $-0,33$ & & & \\
\hline $5 \times 3$ & $-0,94$ & & & \\
\hline $6 \times 3$ & 0,13 & & & \\
\hline $7 \times 3$ & $-0,31$ & & & \\
\hline $8 \times 3$ & 1,50 & & & \\
\hline $9 \times 3$ & $-0,25$ & & & \\
\hline $10 \times 3$ & $-0,13$ & & & \\
\hline $5 \times 4$ & 0,56 & & & \\
\hline $6 \times 4$ & 1,13 & & & \\
\hline $7 \times 4$ & $-0,81$ & & & \\
\hline $8 \times 4$ & $-1,50$ & & & \\
\hline $9 \times 4$ & 0,00 & & & \\
\hline $10 \times 4$ & 0,63 & & & \\
\hline Erro padrão & 0,74 & & & \\
\hline
\end{tabular}




\subsubsection{Produção de frutos por planta}

Ambos os efeitos aditivos e dominantes atuaram na diminuição da produção de frutos por planta (PFP), porém os efeitos aditivos apresentaram uma maior contribuição para a expressão da PFP (Tabela 21). Alguns autores como Gopalakrishnan et al. (1987) e Patel et al. (1998), trabalhando com pimenta, também observaram que os efeitos aditivos sobrepujaram os efeitos dominantes para PFP. O maior valor de foi o apresentado pelo genitor 7 $\left({ }_{7}=0,49\right)$ e o maior valor de $\quad$ ij foi observado no híbrido $5 \times 3(0,41)$, Tabela 21.

\subsubsection{Número de frutos por planta}

A magnitude dos efeitos aditivos foram maiores do que a dos efeitos dominantes para diminuir o número de frutos por planta (NFP), Tabela 22. Estes resultados estão em concordância com os de vários autores : Ahmed et al. (1997), Miranda (1987), Tavares et al. (1997), Vallejo et al. (1997) e outros que também observaram maior contribuição dos efeitos aditivos para NFP. Os

genitores 1 e 7 apresentaram os valores mais altos de $\quad\left({ }_{1}=1,93\right.$ e $\left.\quad{ }_{7}=1,30\right)$. Dentre os híbridos, os que apresentaram maiores valores de ij foram : 5x1 $(1,10), 10 \times 2(2,79)$ e $6 \times 4(1,48)$, Tabela 22.

\subsubsection{Peso médio de fruto}

Para o caráter peso médio de fruto (PMF), os efeitos aditivos e nãoaditivos contribuíram de maneira muito semelhante, aumentando o caráter, porém com uma ligeira predominância dos efeitos não-aditivos (Tabela 23). Alguns autores também encontraram magnitudes maiores dos efeitos não- 
Tabela 21. Estimativas dos efeitos de média (u), de variedades"per se"( vi e vj ), de heterose varietal ( hi e hj ), das capacidades geral ( gi e gj ) e específica ( sij ) de combinaçi: para o caráter produção de frutos por planta.

\begin{tabular}{|c|c|c|c|c|}
\hline $\begin{array}{c}\text { média } \\
\mathrm{u}=4,22 \pm 0,08\end{array}$ & & $\begin{array}{l}\text { aditivo } \\
-0,41 \pm\end{array}$ & & $\begin{array}{l}\text { dominante } \\
\mathrm{h}=-0,11 \pm 0,10\end{array}$ \\
\hline Genitor & vi & hi & gi & \\
\hline 1 & 0,37 & 0,06 & 0,25 & \\
\hline 2 & 0,28 & $-0,09$ & 0,05 & \\
\hline 3 & 0,29 & $-0,16$ & $-0,02$ & \\
\hline 4 & $-0,93$ & 0,19 & $-0,28$ & \\
\hline Erro padrão & 0,23 & 0,15 & & \\
\hline Genitor & vj & hj & gj & \\
\hline 5 & $-0,06$ & 0,08 & 0,05 & \\
\hline 6 & $-0,48$ & $-0,13$ & $-0,37$ & \\
\hline 7 & 0,32 & 0,33 & 0,49 & \\
\hline 8 & 0,34 & $-0,10$ & 0,07 & \\
\hline 9 & 0,25 & $-0,32$ & $-0,20$ & \\
\hline 10 & $-0,36$ & 0,14 & $-0,04$ & \\
\hline Erro padrão & 0,24 & 0,17 & & \\
\hline Híbrido & sij & & & \\
\hline $5 \times 1$ & $-0,08$ & & & \\
\hline $6 \times 1$ & $-0,18$ & & & \\
\hline $7 \times 1$ & 0,25 & & & \\
\hline $8 \times 1$ & 0,06 & & & \\
\hline $9 \times 1$ & 0,18 & & & \\
\hline $10 \times 1$ & $-0,23$ & & & \\
\hline $5 \times 2$ & $-0,28$ & & & \\
\hline $6 \times 2$ & 0,02 & & & \\
\hline $7 \times 2$ & 0,06 & & & \\
\hline $8 \times 2$ & 0,19 & & & \\
\hline $9 \times 2$ & $-0,18$ & & & \\
\hline $10 \times 2$ & 0,20 & & & \\
\hline $5 \times 3$ & 0,41 & & & \\
\hline $6 \times 3$ & $-0,08$ & & & \\
\hline $7 \times 3$ & $-0,39$ & & & \\
\hline $8 \times 3$ & $-0,09$ & & & \\
\hline $9 \times 3$ & 0,01 & & & \\
\hline $10 \times 3$ & 0,15 & & & \\
\hline $5 \times 4$ & $-0,05$ & & & \\
\hline $6 \times 4$ & 0,24 & & & \\
\hline $7 \times 4$ & 0,09 & & & \\
\hline $8 \times 4$ & $-0,16$ & & & \\
\hline $9 \times 4$ & $-0,01$ & & & \\
\hline $10 \times 4$ & $-0,11$ & & & \\
\hline Erro padrão & 0,21 & & & \\
\hline
\end{tabular}


Tabela 22. Estimativas dos efeitos de média (u), de variedades"per se"( vi e vj ), de heterose varietal ( hi e hj ), das capacidades geral ( gi e gj ) e específica ( sij ) de combinaçi para o caráter número de frutos produzidos por planta.

\begin{tabular}{|c|c|c|c|c|}
\hline $\begin{array}{c}\text { média } \\
\mathrm{u}=24,11 \pm 0,50\end{array}$ & & $\begin{array}{l}\text { aditivo } \\
-3,17 \pm\end{array}$ & & $\begin{array}{l}\text { dominante } \\
h=-0,34 \pm 0,59\end{array}$ \\
\hline Genitor & vi & hi & gi & \\
\hline 1 & 2,89 & 0,48 & 1,93 & \\
\hline 2 & 1,09 & $-0,59$ & $-0,05$ & \\
\hline 3 & 0,85 & $-0,29$ & 0,14 & \\
\hline 4 & $-4,84$ & 0,41 & $-2,01$ & \\
\hline Erro padrão & 1,34 & 0,86 & & \\
\hline Genitor & vj & hj & gj & \\
\hline 5 & $-2,43$ & 0,00 & $-1,22$ & \\
\hline 6 & $-1,99$ & 0,55 & $-0,45$ & \\
\hline 7 & $-1,83$ & 2,21 & 1,30 & \\
\hline 8 & 3,01 & $-0,80$ & 0,71 & \\
\hline 9 & 1,69 & $-1,25$ & $-0,41$ & \\
\hline 10 & 1,57 & $-0,70$ & 0,09 & \\
\hline Erro padrão & 1,41 & 1,00 & & \\
\hline Híbrido & sij & & & \\
\hline $5 \times 1$ & 1,10 & & & \\
\hline $6 \times 1$ & $-0,59$ & & & \\
\hline $7 \times 1$ & 0,06 & & & \\
\hline $8 \times 1$ & 0,19 & & & \\
\hline $9 \times 1$ & 0,97 & & & \\
\hline $10 \times 1$ & $-1,73$ & & & \\
\hline $5 \times 2$ & $-1,16$ & & & \\
\hline $6 \times 2$ & $-0,21$ & & & \\
\hline $7 \times 2$ & $-1,01$ & & & \\
\hline $8 \times 2$ & 0,44 & & & \\
\hline $9 \times 2$ & $-0,86$ & & & \\
\hline $10 \times 2$ & 2,79 & & & \\
\hline $5 \times 3$ & 0,25 & & & \\
\hline $6 \times 3$ & $-0,68$ & & & \\
\hline $7 \times 3$ & 0,28 & & & \\
\hline $8 \times 3$ & $-0,77$ & & & \\
\hline $9 \times 3$ & 0,28 & & & \\
\hline $10 \times 3$ & 0,64 & & & \\
\hline $5 \times 4$ & $-0,19$ & & & \\
\hline $6 \times 4$ & 1,48 & & & \\
\hline $7 \times 4$ & 0,67 & & & \\
\hline $8 \times 4$ & 0,13 & & & \\
\hline $9 \times 4$ & $-0,39$ & & & \\
\hline $10 \times 4$ & $-1,70$ & & & \\
\hline Erro padrão & 1,22 & & & \\
\hline
\end{tabular}


Tabela 23. Estimativas dos efeitos de média (u), de variedades"per se"( vi e vj ), de heterose varietal ( hi e hj ), das capacidades geral ( gi e gj ) e específica ( sij ) de combinaçi para o caráter peso médio de fruto.

\begin{tabular}{|c|c|c|c|c|}
\hline $\begin{array}{c}\text { média } \\
u=176,45 \pm 1,4\end{array}$ & & $\begin{aligned} & \text { aditivo } \\
= & 5,97 \pm 1\end{aligned}$ & & $\begin{array}{l}\text { dominante } \\
\mathrm{h}=6,43 \pm 1,74\end{array}$ \\
\hline Genitor & vi & hi & gi & \\
\hline 1 & $-6,88$ & $-1,23$ & $-4,67$ & \\
\hline 2 & 2,71 & 0,72 & 2,08 & \\
\hline 3 & 6,07 & $-5,03$ & $-2,00$ & \\
\hline 4 & $-1,89$ & 5,53 & 4,59 & \\
\hline Erro padrão & 3,96 & 2,56 & & \\
\hline Genitor & vj & hj & gj & \\
\hline 5 & 13,65 & 5,75 & 12,58 & \\
\hline 6 & $-6,75$ & $-9,15$ & $-12,53$ & \\
\hline 7 & 24,15 & $-2,01$ & 10,07 & \\
\hline 8 & $-6,25$ & 0,27 & $-2,86$ & \\
\hline 9 & $-2,28$ & $-4,47$ & $-5,61$ & \\
\hline 10 & $-22,53$ & 9,62 & $-1,65$ & \\
\hline Erro padrão & 4,17 & 2,95 & & \\
\hline Híbrido & sij & & & \\
\hline $5 \times 1$ & $-11,86$ & & & \\
\hline $6 \times 1$ & $-2,42$ & & & \\
\hline $7 \times 1$ & 7,98 & & & \\
\hline $8 \times 1$ & 3,18 & & & \\
\hline $9 \times 1$ & 0,70 & & & \\
\hline $10 \times 1$ & 2,42 & & & \\
\hline $5 \times 2$ & $-3,28$ & & & \\
\hline $6 \times 2$ & 2,11 & & & \\
\hline $7 \times 2$ & 10,11 & & & \\
\hline $8 \times 2$ & 3,75 & & & \\
\hline $9 \times 2$ & $-1,20$ & & & \\
\hline $10 \times 2$ & $-11,49$ & & & \\
\hline $5 \times 3$ & 14,56 & & & \\
\hline $6 \times 3$ & 1,38 & & & \\
\hline $7 \times 3$ & $-17,00$ & & & \\
\hline $8 \times 3$ & 1,69 & & & \\
\hline $9 \times 3$ & $-1,62$ & & & \\
\hline $10 \times 3$ & 1,00 & & & \\
\hline $5 \times 4$ & 0,57 & & & \\
\hline $6 \times 4$ & $-1,07$ & & & \\
\hline $7 \times 4$ & $-1,09$ & & & \\
\hline $8 \times 4$ & $-8,61$ & & & \\
\hline $9 \times 4$ & 2,12 & & & \\
\hline $10 \times 4$ & 8,07 & & & \\
\hline Erro padrão & 3,62 & & & \\
\hline
\end{tabular}


aditivos : Bhagyalakshmi et al. (1991) em pimenta e Gil et al. (1973) em pimentão; Dentro do grupo 1, os genitores 2 e 4 foram os que contribuíram para o aumento do PMF, apresentando valores positivos de , ${ }_{2}=2,08 \mathrm{e}$ ${ }_{4}=4,59$. No grupo 2 , apenas os genitores 5 e 7 apresentaram valores de positivos ( ${ }_{5}=12,58$ e $\left.{ }_{7}=10,07\right)$. Entre os híbridos, os maiores valores positivos de ij foram encontrados em $7 x 1(7,98), 7 \times 2(10,11), 5 \times 3(14,56)$ e 10x4 (8,07). É interessante o fato de que no híbrido 7x2, além da ij favorável, também houve a contribuição de gi's em ambos os genitores (Tabela 23).

\subsubsection{Comprimento de fruto}

Houve a participação tanto dos efeitos aditivos quanto dos dominantes na manifestação do caráter comprimento de fruto $(\mathrm{CF})$, porém, os efeitos dominantes, que atuaram aumentando o caráter, assumiram magnitudes maiores (Tabela 24). Em pimenta, Ahmed et al. (1998) e Bhagyalakshmi et al. (1991) também encontraram maior importância dos efeitos dominantes para CF. Entre os genitores do grupo 1, estão aqueles com a maior CGC para o aumento do CF : (genitor 3, =0,48) e para a diminuição do CF : (genitor 4, $=-0,65)$. No grupo 2, os genitores 7 e 10 foram os que apresentaram os valores positivos mais altos para CGC $\left({ }_{7}=1,95\right.$ e $\left.{ }_{10}=1,61\right)$ e os genitores $6 \mathrm{e}$ 8 foram os que apresentaram os maiores valores negativos $\left({ }_{6}=-2,39\right.$ e ${ }_{8}=-$ 1,62). Os maiores valores positivos para CEC foram observados nos híbridos $5 \times 3(\mathrm{ij}=1,65)$ e $7 \times 4(\mathrm{ij}=1,26)$ e os maiores valores negativos estão presentes nos híbridos 7x3 ( $\mathrm{ij}=-1,64)$ e $5 \times 4$ ( $\mathrm{ij}=-1,76)$, Tabela 24. Cabe lembrar que, para CF, pode-se orientar a seleção para aumentá-lo ou diminuí-lo, dependendo do mercado que se deseja atender. 
Tabela 24. Estimativas dos efeitos de média (u), de variedades"per se"( vi e vj ), de heterose varietal ( hi e hj ), das capacidades geral ( gi e gj ) e específica ( sij ) de combinaçi para o caráter comprimento de fruto.

\begin{tabular}{|c|c|c|c|c|}
\hline $\begin{array}{c}\text { média } \\
u=14,61 \pm 0,13\end{array}$ & & $\begin{array}{l}\text { aditivo } \\
-0,05 \pm\end{array}$ & & $\begin{array}{l}\text { dominante } \\
h=0,83 \pm 0,15\end{array}$ \\
\hline Genitor & vi & hi & gi & \\
\hline 1 & 1,03 & $-0,29$ & 0,23 & \\
\hline 2 & $-0,42$ & 0,15 & $-0,06$ & \\
\hline 3 & 0,42 & 0,27 & 0,48 & \\
\hline 4 & $-1,04$ & $-0,13$ & $-0,65$ & \\
\hline Erro padrão & 0,35 & 0,22 & & \\
\hline Genitor & vj & hj & gj & \\
\hline 5 & $-0,62$ & 0,08 & $-0,23$ & \\
\hline 6 & $-1,11$ & $-1,83$ & $-2,39$ & \\
\hline 7 & 4,13 & $-0,12$ & 1,95 & \\
\hline 8 & $-3,16$ & $-0,04$ & $-1,62$ & \\
\hline 9 & $-0,47$ & 0,91 & 0,68 & \\
\hline 10 & 1,24 & 0,99 & 1,61 & \\
\hline Erro padrão & 0,36 & 0,26 & & \\
\hline Híbrido & sij & & & \\
\hline $5 \times 1$ & 0,25 & & & \\
\hline $6 \times 1$ & $-0,54$ & & & \\
\hline $7 \times 1$ & 0,06 & & & \\
\hline $8 \times 1$ & $-0,50$ & & & \\
\hline $9 \times 1$ & 0,03 & & & \\
\hline $10 \times 1$ & 0,69 & & & \\
\hline $5 \times 2$ & $-0,15$ & & & \\
\hline $6 \times 2$ & $-0,01$ & & & \\
\hline $7 \times 2$ & 0,32 & & & \\
\hline $8 \times 2$ & 0,44 & & & \\
\hline $9 \times 2$ & $-0,94$ & & & \\
\hline $10 \times 2$ & 0,33 & & & \\
\hline $5 \times 3$ & 1,65 & & & \\
\hline $6 \times 3$ & 0,21 & & & \\
\hline $7 \times 3$ & $-1,64$ & & & \\
\hline $8 \times 3$ & $-0,78$ & & & \\
\hline $9 \times 3$ & 0,62 & & & \\
\hline $10 \times 3$ & $-0,06$ & & & \\
\hline $5 \times 4$ & $-1,76$ & & & \\
\hline $6 \times 4$ & 0,33 & & & \\
\hline $7 \times 4$ & 1,26 & & & \\
\hline $8 \times 4$ & 0,84 & & & \\
\hline $9 \times 4$ & 0,29 & & & \\
\hline $10 \times 4$ & $-0,97$ & & & \\
\hline Erro padrão & 0,32 & & & \\
\hline
\end{tabular}




\subsubsection{Diâmetro de fruto}

$\mathrm{Na}$ expressão do diâmetro de fruto (DF), houve contribuição tanto dos efeitos aditivos quanto dos não-aditivos, estes últimos com uma magnitude maior, no sentido de diminuí-lo (Tabela 25). Da mesma forma, Bhagyalakshmi et al. (1991) e Doshi \& Shukla (2000c) relataram terem observado em pimenta uma maior contribuição da ação gênica não-aditiva para largura de fruto. Os genitores 4,5 e 8 foram os que mais contribuíram para o aumento do DF, apresentando os maiores valores positivos de $\quad:{ }_{4}=0,35, \quad{ }_{5}=0,13$ e $\quad{ }_{8}=0,20$. Os híbridos que apresentaram os maiores valores positivos de ij foram $6 \mathrm{x} 2$ $(0,27), 8 \times 2(0,26), 5 \times 4(0,31)$ e $10 \times 4(0,28)$, Tabela 25 .

\subsubsection{Espessura de pericarpo de fruto}

$\mathrm{Na}$ espessura de pericarpo de fruto (EP) atuaram tanto os efeitos gênicos aditivos quanto os não-aditivos, tendo os primeiros predominado no sentido de diminuir a EP (Tabela 26). Ahmed et al. (1997), Ahmed et al. (1998) e Bem-Chaim \& Paran (2000) também observaram uma maior contribuição dos efeitos aditivos tanto em pimentão quanto em pimenta. Dentre os dez genitores, o que apresentou a maior participação, aumentando o caráter foi o genitor $10 \mathrm{com} \quad{ }_{10}=0,48$. Entre os híbridos, o maior destaque foi para $7 \mathrm{x} 1$ e 10x3, que apresentaram os maiores valores de ${ }_{\mathrm{ij}}:{ }_{7 \times 1}=0,31 \mathrm{e}$ ${ }_{10 \times 3}=0,34$ (Tabela 26). 
Tabela 25. Estimativas dos efeitos de média (u), de variedades"per se"( vi e vj ), de heterose varietal ( hi e hj ), das capacidades geral ( gi e gj ) e específica ( sij ) de combinaçi para o caráter diâmetro de fruto.

\begin{tabular}{|c|c|c|c|c|}
\hline $\begin{array}{c}\text { média } \\
\mathrm{u}=7,78 \pm 0,06\end{array}$ & & $\begin{array}{l}\text { aditivo } \\
0,03 \pm 0\end{array}$ & & $\begin{array}{l}\text { dominante } \\
h=-0,08 \pm 0,07\end{array}$ \\
\hline Genitor & vi & hi & gi & \\
\hline 1 & $-0,30$ & $-0,08$ & $-0,23$ & \\
\hline 2 & 0,22 & $-0,08$ & 0,03 & \\
\hline 3 & $-0,16$ & $-0,09$ & $-0,17$ & \\
\hline 4 & 0,23 & 0,23 & 0,35 & \\
\hline Erro padrão & 0,15 & 0,10 & & \\
\hline Genitor & vj & hj & gj & \\
\hline 5 & 0,26 & 0,00 & 0,13 & \\
\hline 6 & $-0,09$ & 0,12 & 0,08 & \\
\hline 7 & 0,04 & 0,03 & 0,05 & \\
\hline 8 & 0,58 & $-0,09$ & 0,20 & \\
\hline 9 & $-0,36$ & 0,12 & $-0,06$ & \\
\hline 10 & $-0,44$ & $-0,18$ & $-0,40$ & \\
\hline Erro padrão & 0,16 & 0,11 & & \\
\hline Híbrido & sij & & & \\
\hline $5 \times 1$ & $-0,10$ & & & \\
\hline $6 \times 1$ & $-0,04$ & & & \\
\hline $7 \times 1$ & 0,17 & & & \\
\hline $8 \times 1$ & 0,05 & & & \\
\hline $9 \times 1$ & 0,08 & & & \\
\hline $10 \times 1$ & $-0,15$ & & & \\
\hline $5 \times 2$ & $-0,36$ & & & \\
\hline $6 \times 2$ & 0,27 & & & \\
\hline $7 \times 2$ & 0,08 & & & \\
\hline $8 \times 2$ & 0,26 & & & \\
\hline $9 \times 2$ & $-0,11$ & & & \\
\hline $10 \times 2$ & $-0,14$ & & & \\
\hline $5 \times 3$ & 0,15 & & & \\
\hline $6 \times 3$ & $-0,11$ & & & \\
\hline $7 \times 3$ & $-0,04$ & & & \\
\hline $8 \times 3$ & 0,05 & & & \\
\hline $9 \times 3$ & $-0,06$ & & & \\
\hline $10 \times 3$ & 0,01 & & & \\
\hline $5 \times 4$ & 0,31 & & & \\
\hline $6 \times 4$ & $-0,12$ & & & \\
\hline $7 \times 4$ & $-0,21$ & & & \\
\hline $8 \times 4$ & $-0,36$ & & & \\
\hline $9 \times 4$ & 0,10 & & & \\
\hline $10 \times 4$ & 0,28 & & & \\
\hline Erro padrão & 0,14 & & & \\
\hline
\end{tabular}


Tabela 26. Estimativas dos efeitos de média (u), de variedades"per se"( vi e vj ), de heterose varietal ( hi e hj ), das capacidades geral ( gi e gj ) e específica ( sij ) de combinaçi para o caráter espessura de pericarpo de fruto.

\begin{tabular}{|c|c|c|c|c|}
\hline $\begin{array}{c}\text { média } \\
u=5,48 \pm 0,08\end{array}$ & & $\begin{array}{l}\text { aditivo } \\
-0,22 \pm\end{array}$ & & $\begin{array}{l}\text { dominante } \\
h=-0,02 \pm 0,09\end{array}$ \\
\hline Genitor & vi & hi & gi & \\
\hline 1 & $-0,27$ & 0,03 & $-0,11$ & \\
\hline 2 & 0,21 & $-0,03$ & 0,08 & \\
\hline 3 & $-0,09$ & $-0,11$ & $-0,16$ & \\
\hline 4 & 0,15 & 0,10 & 0,18 & \\
\hline Erro padrão & 0,21 & 0,13 & & \\
\hline Genitor & vj & hj & gj & \\
\hline 5 & 0,24 & 0,00 & 0,12 & \\
\hline 6 & $-0,29$ & 0,01 & $-0,14$ & \\
\hline 7 & 0,37 & $-0,25$ & $-0,07$ & \\
\hline 8 & $-0,50$ & 0,04 & $-0,21$ & \\
\hline 9 & $-0,16$ & $-0,1$ & $-0,18$ & \\
\hline 10 & 0,32 & 0,32 & 0,48 & \\
\hline Erro padrão & 0,22 & 0,15 & & \\
\hline Híbrido & sij & & & \\
\hline $5 \times 1$ & 0,00 & & & \\
\hline $6 \times 1$ & 0,18 & & & \\
\hline $7 \times 1$ & 0,31 & & & \\
\hline $8 \times 1$ & $-0,14$ & & & \\
\hline $9 \times 1$ & $-0,01$ & & & \\
\hline $10 \times 1$ & $-0,34$ & & & \\
\hline $5 \times 2$ & $-0,04$ & & & \\
\hline $6 \times 2$ & $-0,01$ & & & \\
\hline $7 \times 2$ & 0,13 & & & \\
\hline $8 \times 2$ & 0,03 & & & \\
\hline $9 \times 2$ & $-0,05$ & & & \\
\hline $10 \times 2$ & $-0,06$ & & & \\
\hline $5 \times 3$ & 0,11 & & & \\
\hline $6 \times 3$ & $-0,10$ & & & \\
\hline $7 \times 3$ & $-0,44$ & & & \\
\hline $8 \times 3$ & 0,07 & & & \\
\hline $9 \times 3$ & 0,02 & & & \\
\hline $10 \times 3$ & 0,34 & & & \\
\hline $5 \times 4$ & $-0,07$ & & & \\
\hline $6 \times 4$ & $-0,06$ & & & \\
\hline $7 \times 4$ & $-0,01$ & & & \\
\hline $8 \times 4$ & 0,04 & & & \\
\hline $9 \times 4$ & 0,04 & & & \\
\hline $10 \times 4$ & 0,06 & & & \\
\hline Erro padrão & 0,19 & & & \\
\hline
\end{tabular}




\subsubsection{Número de lóculos por fruto}

Os efeitos gênicos aditivos, os quais atuaram aumentando o número de lóculos (NL) por fruto, participaram mais expressivamente do que os efeitos dominantes na definição do NL (Tabela 27). Resultado semelhante foi encontrado por Miranda (1987) em pimentão. O genitor 10 foi o que mais contribuiu para o aumento do NL, apresentando o maior valor positivo de $(0,21)$. Os maiores valores de ij foram encontrados nos híbridos $8 \times 1(0,15)$, $5 \times 2(0,10), 7 \times 3(0,14)$ e $10 \times 3(0,14)$, Tabela 27. 
Tabela 27. Estimativas dos efeitos de média (u), de variedades"per se"( vi e vj ), de heterose varietal ( hi e hj ), das capacidades geral ( gi e gj ) e específica ( sij ) de combinaçi para o caráter número de lóculos por fruto.

\begin{tabular}{|c|c|c|c|c|}
\hline $\begin{array}{c}\text { média } \\
\mathrm{u}=3,57 \pm 0,04\end{array}$ & & $\begin{array}{l}\text { aditive } \\
0,15 \pm\end{array}$ & & $\begin{array}{l}\text { dominante } \\
h=-0,06 \pm 0,05\end{array}$ \\
\hline Genitor & vi & hi & gi & \\
\hline 1 & 0,05 & 0,03 & 0,06 & \\
\hline 2 & 0,15 & $-0,03$ & 0,05 & \\
\hline 3 & $-0,12$ & $-0,07$ & $-0,13$ & \\
\hline 4 & $-0,07$ & 0,07 & 0,04 & \\
\hline Erro padrão & 0,11 & 0,07 & & \\
\hline Genitor & vj & hj & gj & \\
\hline 5 & 0,03 & 0,09 & 0,11 & \\
\hline 6 & $-0,27$ & $-0,07$ & $-0,21$ & \\
\hline 7 & $-0,22$ & $-0,03$ & $-0,14$ & \\
\hline 8 & 0,10 & $-0,09$ & $-0,04$ & \\
\hline 9 & 0,25 & $-0,02$ & 0,11 & \\
\hline 10 & 0,13 & 0,14 & 0,21 & \\
\hline Erro padrão & 0,11 & 0,08 & & \\
\hline Híbrido & sij & & & \\
\hline $5 \times 1$ & $-0,15$ & & & \\
\hline $6 \times 1$ & 0,01 & & & \\
\hline $7 \times 1$ & $-0,05$ & & & \\
\hline $8 \times 1$ & 0,15 & & & \\
\hline $9 \times 1$ & 0,06 & & & \\
\hline $10 \times 1$ & $-0,02$ & & & \\
\hline $5 \times 2$ & 0,10 & & & \\
\hline $6 \times 2$ & 0,07 & & & \\
\hline $7 \times 2$ & $-0,06$ & & & \\
\hline $8 \times 2$ & 0,01 & & & \\
\hline $9 \times 2$ & 0,07 & & & \\
\hline $10 \times 2$ & $-0,19$ & & & \\
\hline $5 \times 3$ & $-0,01$ & & & \\
\hline $6 \times 3$ & $-0,15$ & & & \\
\hline $7 \times 3$ & 0,14 & & & \\
\hline $8 \times 3$ & $-0,08$ & & & \\
\hline $9 \times 3$ & $-0,03$ & & & \\
\hline $10 \times 3$ & 0,14 & & & \\
\hline $5 \times 4$ & 0,06 & & & \\
\hline $6 \times 4$ & 0,07 & & & \\
\hline $7 \times 4$ & $-0,03$ & & & \\
\hline $8 \times 4$ & $-0,08$ & & & \\
\hline $9 \times 4$ & $-0,09$ & & & \\
\hline $10 \times 4$ & 0,07 & & & \\
\hline Erro padrão & 0,10 & & & \\
\hline
\end{tabular}




\section{CONCLUSÕES}

Para as condições nas quais este trabalho foi desenvolvido, pode-se concluir que :

1) A heterose em relação à média dos genitores manifestou-se principalmente nos caracteres altura de planta na maturidade, produção de frutos por planta, número de frutos por planta, peso médio de fruto, comprimento de fruto e espessura de pericarpo de fruto. Já em relação aos genitores resistentes ao PVY (Potato Virus Y ou Vírus Y da Batata), a heterose ocorreu principalmente para altura de planta na maturidade, produção de frutos por planta, número de frutos por planta e espessura de pericarpo de fruto; 2) A heterose-padrão foi mais destacada nos caracteres altura de planta na maturidade, produção de frutos por planta, peso médio de fruto, comprimento de fruto, diâmetro de fruto, espessura de pericarpo de fruto e número de lóculos por fruto. Foi detectada heterobeltiose apenas nos caracteres comprimento de fruto e peso médio de fruto; 3) Houve maior importância dos efeitos gênicos aditivos no controle dos caracteres altura de planta na maturidade, número de dias para o florescimento, produção e número de frutos por planta, espessura de pericarpo de fruto e número de lóculos por fruto. Já as heranças dos caracteres número de dias para a maturidade, peso médio, comprimento e diâmetro de fruto envolveram principalmente efeitos de dominância gênica; 4) A participação de ambas capacidade específica e geral de combinação na determinação dos valores dos caracteres altura de planta na 
maturidade, peso médio e comprimento de fruto, apontam para a vantagem da utilização de híbridos de pimentão. 


\section{REFERÊNCIAS BIBLIOGRÁFICAS}

ADO, S.G. Gene action in six crosses of pepper (Capsicum annиuт L.). Capsicum Newsletter, n.7, p.52-53, 1988.

AHMED, N.; BHAT, M.Y.; TANKI, M.I.; ZARGAR, G.H. Inheritance of yield attributing characters in pepper (Capsicum annиum L.). Capsicum and Eggplant Newsletter, n.13, p.58-60, 1994.

AHMED, N.; KHAN, S.H.; TANKI, M.I. Combining ability analysis for fruit yield and its component characters in sweet pepper (Capsicum annuиm L.). Capsicum and Eggplant Newsletter, n.16, p.72-75, 1997.

AHMED, N.; SHAH, F.A.; ZARGAR, G.H.; WANI, S.A. Line x tester analysis for the study of combining ability in hot pepper (Capsicum аппиит L.). Capsicum and Eggplant Newsletter, n.17, p.38-41, 1998.

AHMED, N.; HURRA, M. Heterosis studies for fruit yield and some economic characters in sweet peppers (Capsicum annиит L.). Capsicum and Eggplant Newsletter, n.19, p.74-77, 2000.

BEM-CHAIM, A.; PARAN, I. Genetic analysis of quantitative traits in pepper (Capsicum аппиит). Journal of American Society Horticultural Science, v.125, n.1, p.66-70, 2000.

BHAGYALAKSHMI, P.V.; RAVI SHANKAR, C.; SUBRAHMANYAM, D.; GANESH BABU, V. Heterosis and combining ability studies in chillies. The Indian Journal of Genetics, v.51, n.4, p.420-423, 1991.

BOSLAND, P.W.; VOTAVA, E.J. Peppers: vegetable and spice capsicums. Las Cruces: CABI Publishing, 2000. 204p. 
CASALI, V.W.D.; COUTO, F.A.A. Origem e botânica de Capsicum. Informe Agropecuário, v.10, n.113, p.8-10, 1984.

CRUZ, C.D. Programa GENES: versão windows (software). 2.ed. Viçosa: UFV, 2001. 648p.

DEPESTRE, T.; ESPINOSA, J. Estudio del efecto de heterosis en el pimiento (Capsicum annuum) en condiciones tropicales. Agrotecnia de Cuba, v.20, n.1, p.87-90, 1988 .

DOSHI, K.M.; SHUKLA, P.T. Expression of heterosis in chilli (Capsicum апnиит L.). Capsicum and Eggplant Newsletter, n.19, p.66-69, 2000a.

DOSHI, K.M.; SHUKLA, P.T. Genetic of yield and its components in chilli (Capsicum annuиm L.). Capsicum and Eggplant Newsletter, n.19, p.78$81,2000 \mathrm{~b}$.

DOSHI, K.M.; SHUKLA, P.T. Combining ability analysis for fresh fruit yield and its components over enviroments in chilli (Capsicum annuum L.). Capsicum and Eggplant Newsletter, n.19, p.82-85, 2000c.

DOSHI, K.M.; SHUKLA, M.R.; KATHIRIA, K. B. Seedling analysis for the prediction of heterosis and combining ability in chilli (Capsicum annuum L.). Capsicum and Eggplant Newsletter, v.20, p.46-49, 2001.

DUNNET, C.W. A multiple comparison procedure for comparing several treatments with a control. Journal of the American Statistical Association, v.50, n.72, p.1096-1120, 1995.

FALCONER, D. S. Introdução à genética quantitativa. Viçosa: UFV, Imprensa Universitária, 1987. 279p.

FAO. FAO Production Yearbook, v.52, p.133-134, 1998.

FISHER, R.A.; YATES, F. Statistical tables for biological agricultural and medical research. New York: Hafner Publishing, 1963. p.63.

GARDNER, C.O.; EBERHART, S.A. Analysis and interpretation of the variety cross diallel and related populations. Biometrics, v.22, p.439-452, 1966. 
GILL, H.S.; THAKUR, P.C.; THAKUR, T.C. Combining ability in sweet pepper ( Capsicum annuum L. var. grossum Sendt. ). Indian Journal of Agricultural Science, v.43, n.10, p.918-921, 1973.

GOPALAKRISHNAN, T.R.; GOPALAKRISHNAN, P.K.; PETER, K.V. Heterosis and combining ability analysis in chilli. The Indian Journal of Genetics, v.47, n.2, p.205-209, 1987.

IKUTA, H. Vigor de híbridos na geração F1 em berinjela (Solanun melongena L.). Piracicaba, 1961. 41p. Tese (Doutorado) - Escola Superior de Agricultura "Luiz de Queiroz", Universidade de São Paulo.

IKUTA, H. Ensaio de híbridos F1, F2 e variedades resistentes a vírus de pimentão (Capsicum annuum L.). Revista de Olericultura, v.11, p.64, 1971.

IKUTA, H.; VENCOVSKY, R. Ensaio de híbridos F1 de variedades de pimentão resistentes a viroses. Piracicaba: ESALQ, Depto. Genética, 1970. p.62-64. (Relatório científico, 4)

JOSHI, S.; THAKUR, P.C.; VERMA, T.S.; VERMA, H.C. Intervarietal crossing of bell and hot pepper augments the hybrid seed yield. Capsicum Newsletter, n.10, p.53-54, 1991.

KORDUS, R. Heterosis in F1 hybrids of hot pepper (Capsicum annuum L.). Capsicum Newsletter, n.10, p.51-52, 1991.

KUMAR, R.; LAL, G. Expression of heterosis in hot pepper (Capsicum aпnиит L.). Capsicum and Eggplant Newsletter, n.20, p.38-41, 2001.

KUMAR, S.; BANERJEE, M.K.; KALLOO, G. Morpho-cytological features of a heterotic sweet pepper $\mathrm{x}$ hot pepper hybrid : promissing for pickle type cultivation and recombinant inbred lines dvelopment. Capsicum and Eggplant Newsletter, n.19, p.54-57, 2000.

MAMEDOV, M.I.; PYSHNAJA, O.N. Heterosis and correlations studies for earliness, fruit yield and some economic characteristics in sweet pepper. Capsicum and Eggplant Newsletter, n.20, p.42-45, 2001. 
MELO, A.M.T. Análise genética de caracteres de fruto em híbridos de pimentão. Piracicaba, 1997. 108p. Tese (Doutorado) - Escola Superior de Agricultura "Luiz de Queiroz", Universidade de São Paulo.

MING, W.; XIAOMING, H.; DEHUA, M. Heterosis and correlation between F1 hybrids and their parents in pepper (Capsicum annuum L.). In: EUCARPIA MEETING ON GENETICS AND BREEDING ON CAPSICUM AND EGGPLANT, 6., Zaragoza, 1986. Proceedings. Sta. Cruz de Tenerife: Ino Reproducciones, 1986. p.61-65.

MIRANDA, J.E.C. de. Avaliação de seis cultivares de tomate (Licopersicon esculentum Mill.) e suas progênies híbridas F1. Viçosa, 1978. 42p. Tese (Mestrado) - Universidade Federal de Viçosa.

MIRANDA, J.E.C. Análise genética de um cruzamento dialélico em pimentão (Capsicum annum L.). Piracicaba, 1987. 159p. Tese (Doutorado) Escola Superior de Agricultura "Luiz de queiroz", Universidade de São Paulo.

MIRANDA FILHO, J.B.; GERALDI, I.O. An adapted model for the analysis of partial diallel crosses. Revista Brasileira de Genética, v.7, p.667-688, 1984.

MISHRA, R.S.; LOTHA, R.E.; MISHRA, S.N.; PAUL, P.K.; MISHRA, H.N. Results of heterosis breeding on chilli (Capsicum annuum L.). Capsicum Newsletter, n.7, p.49-50, 1988.

NAMESNY, A. Pimientos. (Coleccion compendios de horticultura). S.1.: Ediciones de Horticultura, 1996. 167p.

NUEZ VINALS, F.; GIL ORTEGA, R.; COSTA GARCIA, J. El cultivo de pimientos, chiles y ajies. Madrid: Ediciones Mundi-Prensa, 1996. 607p.

PANAYOTOV, N.; GHEORGHIEV, V.; IVANOVA, I. Characteristics and grouping of F1 pepper (Capsicum annuum L.) hybrids on the basis of cluster analysis by morphological characteristics of fruit. Capsicum and Eggplant Newsletter, n.19, p.62-65, 2000. 
PATEL, J.A.; SHUKLA, M.R.; DOSHI, K.M.; PATEL, B.R ; PATEL, S.A. Combining ability analysis for green fruit yield and components in Chilli (Capsicum annuum L.). Capsicum and Eggplant Newsletter, n.17, p.3437, 1998.

PEARSON, O.H. Heterosis in vegetable crops. In: FRANKEL, R. (Ed.). Heterosis: reappraisal of theory and practice. Berlin: Springer-Verlag, 1983. Chap.6, p.138-188.

PICKERSGILL, B. The domestication of chilli peppers. In: UCKO, P.J.; DIMBLEY, G.W. (Ed.). The domestication and exploitation of plants and Animals. London: Chapman and Hall, 1969. p.443-450.

PICKERSGILL, B. Genetic resources and breeding of Capsicum spp. Euphytica, v.96, p.129-133, 1997.

SCOTT, A.J.; KNOTT, M. A cluster analysis method for grouping means in the analysis of variance. Biometrics, v.30, n.3, p.507-512, 1974.

TAVARES, M.; MELO, A.M.T.; SCIVITTARO, W.B.; TESSARIOLI NETO, J. Coeficiente de correlação entre médias parentais e híbridos F1 em um cruzamento dialélico de pimentão. Revista Ecossistema, v.22, p.64-67, 1997.

TAVARES, M.; MELO, A.M.T.; SCIVITTARO, W.B. Efeitos diretos e indiretos e correlações canônicas para caracteres relacionados com a produção de pimentão. Bragantia, v.58, n.1, p.41-47, 1999.

TODOROVA, V. Heterosis and inheritance of quantitative characters in red pepper for grinding (C. аппиит L.). Capsicum and Eggplant Newsletter, n. 19, p.70-73, 2000.

VALLEJO C., F.A.; CEBALlOS L., H.; ECHEVERRI AGUDELO, A. Analisis genetico de una poblacion dialelica de pimenton (Capsicum annuиm L.). Acta Agronomica, v.47, n.4, p.25-36, 1997. 